Published in final edited form as:

J Org Chem. 2016 September 02; 81(17): 7862-7883. doi:10.1021/acs.joc.6b01516.

\title{
Synthesis and Biological Evaluation of Several Bryostatin Analogues Bearing a Diacylglycerol Lactone C-Ring
}

\author{
David O. Baumann ${ }^{\dagger}$, Kevin M. McGowan ${ }^{\dagger}$, Noemi Kedei $^{\ddagger}$, Megan L. Peach ${ }^{\S}$, Peter M. \\ Blumberg $^{\ddagger}$, Gary E. Keck ${ }^{\star}, \dagger$ \\ †Department of Chemistry, University of Utah, 315 S 1300 E, RM 2020, Salt Lake City, Utah \\ 84112, United States \\ ‡Laboratory of Cancer Biology and Genetics, Center for Cancer Research, National Cancer \\ Institute, Bethesda, Maryland 20892-4255, United States \\ §Basic Science Program, Leidos Biomedical Research, Inc., Chemical Biology Laboratory, \\ Frederick National Laboratory for Cancer Research, Frederick, Maryland 21702, United States
}

\begin{abstract}
As an initial step in designing a simplified bryostatin hybrid molecule, three bryostatin analogues bearing a diacylglycerol lactone-based C-ring, which possessed the requisite pharmacophores for binding to protein kinase $\mathrm{C}$ ( $\mathrm{PKC}$ ) together with a modified bryostatin-like A- and B-ring region, were synthesized and evaluated. Merle 46 and Merle 47 exhibited binding affinity to PKC alpha with $K_{\mathrm{i}}$ values of $7000 \pm 990$ and $4940 \pm 470 \mathrm{nM}$, respectively. Reinstallation of the trans-olefin and gem-dimethyl group present in bryostatin 1 in Merle 48 resulted in improved binding affinity, $363 \pm 42 \mathrm{nM}$. While Merle 46 and 47 were only marginally active biologically, Merle 48 showed sufficient activity on the U937 cells to confirm that it was PMA-like for growth and attachment, as predicted by the substitution pattern of its A-and B-rings.
\end{abstract}

\section{Graphical Abstract}

\footnotetext{
*Corresponding Author: keck@chem.utah.edu.

Supporting Information

The Supporting Information is available free of charge on the ACS Publications website at DOI: 10.1021/acs.joc.6b01516.

${ }^{1} \mathrm{H}$ and ${ }^{13} \mathrm{C}$ NMR spectra of all new compounds(PDF)

The authors declare no competing financial interest.

DEDICATION

We would like to dedicate this paper to the life and memory of our dear friend and continual source of inspiration, Dr. Merle Haggard, the namesake for the compounds in this series.
} 


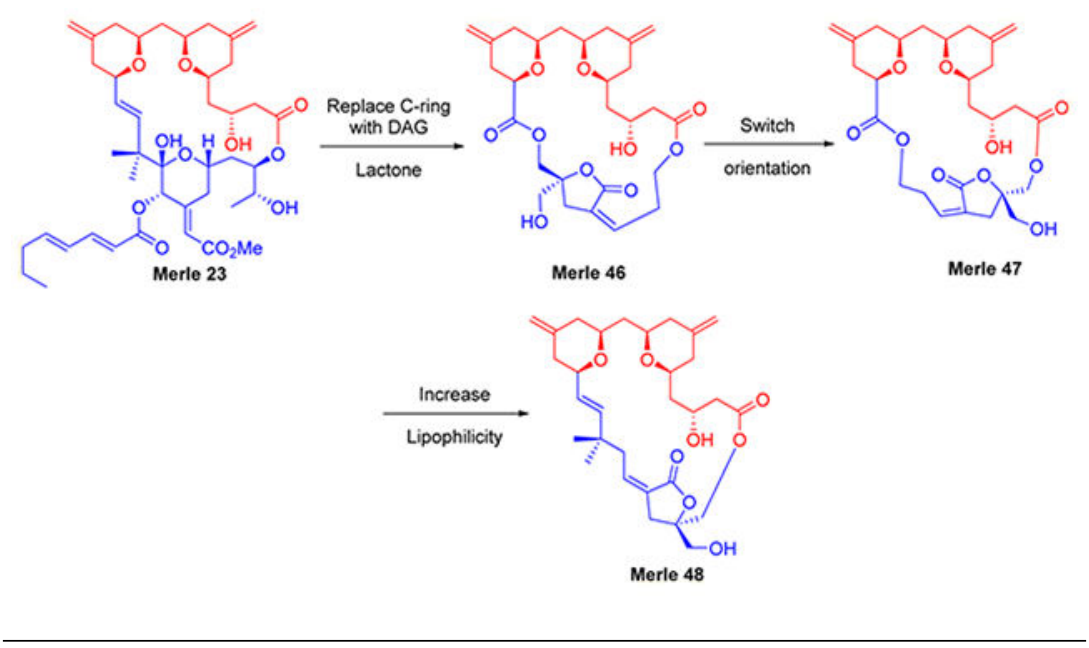

The bryostatins are a class of 20 natural products that consist of a 20-membered macrolactone bearing three embedded pyran rings and were originally isolated by Pettit from the marine bryozoan Bugula neritina (Figure 1). ${ }^{1}$ Bryostatin 1 was shown to be a potent antitumor agent in vivo and has been evaluated in over 80 clinical trials to date. ${ }^{2-4}$ Bryostatin 1 was shown to exhibit synergy in combination with a number of known chemotherapeutic agents, but results as a single agent in humans were unsatisfactory. Bryostatin 1 has demonstrated the ability to activate latent HIV in vitro, potentially allowing for complete destruction of the virus when used in combination with the anti-retroviral therapy HAART. ${ }^{5}$ Additionally, bryostatin 1 has been investigated as a treatment for stroke and was shown to reduce the severity of the effects of stroke in rats. ${ }^{6}$ Bryostatin 1 is also in clinical trials for the treatment of Alzheimer's disease. ${ }^{7}$

Bryostatin 1 binds with single-digit nanomolar affinity to the $\mathrm{C} 1$ domains of protein kinase $\mathrm{C}$ (PKC) and several related families of signaling proteins, such as RasGRP. These proteins mediate central cellular signaling pathways and play a role in numerous disease processes, including cancer and neurological conditions. ${ }^{8,9}$ The bryostatins are ultrapotent mimetics of diacylglycerols (DAGs), which represent the endogenous ligands for the $\mathrm{C} 1$ domains of PKC. ${ }^{10}$ Many PKC activators (such as the phorbol esters, of which phorbol 12-myristate 13acetate (PMA) is the prototype) are potent tumor promotors. ${ }^{11}$ Bryostatin 1 , in contrast, is not tumor-promoting and has been shown to both block and actually reverse the effects of phorbol esters in a dose-dependent manner. ${ }^{12,13}$ It is this unique combination of high binding affinity for PKC coupled with the functional ability to block many PKC-mediated responses which sets the bryostatins apart from the other $\mathrm{C} 1$ domain targeted PKC ligands.

A goal of functional synthesis is to preserve the desired functional activities of a compound while eliminating irrelevant synthetic complexity. The bryostatins incorporate two critical functional activities. First, they bind to the $\mathrm{C} 1$ domain of PKC. Second, they act as functional antagonists of many of the PKC-mediated responses to the phorbol esters. The critical structural element conferring on bryostatin the $\mathrm{C} 1$ binding activity is the lower $(\mathrm{C}$ ring) region. In contrast, appropriately functionalized A- and B-rings are necessary for the ability of bryostatin to act as an antagonist rather than as an analogue of the phorbol esters. 14-16 Importantly, neristatin 1 showed that the functionalized A- and B-rings were not only 
necessary but sufficient to confer bryostatin-like biological activity, provided that the compound could still bind to $\mathrm{PKC}$; the C-region of neristatin 1 is distinct from that of bryostatin but is still capable of binding. ${ }^{17}$ These results suggested that it might be possible to develop simplified bryostatin analogues retaining the unique biological functionality of bryostatin by coupling a bryostatin-like A- and B-region to a bottom half of convenience that was capable of conferring $\mathrm{C} 1$ binding activity, provided that region maintained whatever interactions were necessary between the two halves. Among such templates with appropriate binding activity, the DAG-lactones represent a combination of structural simplicity and potential high affinity. ${ }^{18}$

The current study represents an initial exploration of the feasibility of this strategy. Previous work conducted by our group has resulted in a library of bryostatin analogues bearing simplified AB-ring top halves. ${ }^{19-21}$ All of our previous work has relied upon the synthesis and utilization of a fully functionalized C-ring through a $17-19$ step route. ${ }^{22}$

Several models have been reported for the binding of PKC ligands to the $\mathrm{C} 1$ domain. ${ }^{23}$ The binding hypothesis proposed by Kang and co-workers appears to be consistent with the experimental results reported to date (Figure 2) ${ }^{20}$ All binding models have relied upon a three-point pharmacophore hypothesis; any simplified C-ring would have to contain suitable surrogate functionality in the proper orientation for binding. Our current understanding of bryostatin binding is that the $\mathrm{C} 1$ ester, the $\mathrm{C} 26$ alcohol, and $\mathrm{C} 21$ enoate carbonyl are largely responsible for $\mathrm{PKC}$ binding. ${ }^{20}$ The $\mathrm{C} 3$ hydroxyl and $\mathrm{C} 19$ hemiketal are also very important as these are involved, along with the A and B-ring pyran oxygens, in forming an intramolecular H-bonding network, providing rigidity to the macrocycle. The $\mathrm{C} 9$ hydroxyl group present in the natural product is not required for high affinity but presumably may help anchor the top half of the molecule to the protein surface. ${ }^{20}$

The Marquez diacylglycerol lactones are potent PKC ligands that can still retain low nanomolar affinity for PKC when constrained into macrocyclic rings that are similar in size to the bryostatins. ${ }^{24,25}$ The Marquez lactones bear functionality similar to that of the binding motif of bryostatin 1 . The most potent DAG lactones possess a $Z$-enoate with a bulky end substituent, a free $\gamma$-hydroxymethyl, and a $\gamma$-hydroxymethyl esterified to a bulky carboxylic acid. ${ }^{26}$ We envisioned that a DAG lactone subunit could perhaps function as a suitable replacement for the complex C-ring (primary binding subunit) of bryostatin 1. Depending on ring size and associated lipophilicity, macrocyclic DAG lactones have been described displaying affinities ranging from $6.1 \mathrm{nM}$ to $1.8 \mu \mathrm{M}$ (Figure 3). At least for the nonmacrocyclic DAG lactones, $\log P$ values of 4-6 appear to be optimal for PKC binding. ${ }^{27}$

Replacement of the natural C-ring of bryostatin 1 in our most studied analogue, Merle 23, with a Marquez DAG lactone was envisioned to be a suitable platform for testing this idea. Marquez and co-workers demonstrated that the optimum configuration for PKC binding of DAG lactones is opposite from that of the endogenous DAGs due to the constrained nature of the DAG lactone. ${ }^{25}$ The optimum attachment points for the DAG lactone to the simplified AB-ring system were unknown, thus two analogues, Merles 46 and 47 were initially targeted to determine the optimum orientation. Suitable linker groups for the enoate and ester were chosen to retain the optimum ring size of the macrocyclic Marquez lactones, although this, 
of course, would not simultaneously provide a match for the lipophilicity of bryostatin-like compounds. ${ }^{15}$

\section{RESULTS AND DISCUSSION}

The retrosynthesis of the first two analogues involved the disconnection of the $\mathrm{C} 1$ ester and the $\mathrm{C} 16$ ester, giving $\mathrm{AB}$ carboxylic acid $\mathbf{1}$ and enoate $\mathbf{2}$. The bispyran $\mathbf{1}$ could be approached by pyran annulation as in previous reports from our group, while the enoate 2 could be accessed by an aldol condensation (Scheme 1).

The $\mathrm{AB}$ acid $\mathbf{1}$ was accessed by an optimized route from known $\beta$-hydroxyallylsilane 3 . $^{28}$ Pyran annulation ${ }^{29}$ of known aldehyde $4^{30}$ with $\beta$-hydroxyallylsilane 3 produced bispyran 5 in moderate yield. Deprotection of the C16 TBS group in the presence of the C1 TBDPS was accomplished with $\mathrm{ZrCl}_{4}$ in 2-propanol, producing alcohol $\mathbf{6}$ in good yield. ${ }^{31}$ An acetate derivative $\mathbf{6 b}$ of alcohol $\mathbf{6}$ was also prepared and used to confirm the stereochemistry of the new pyran ring via 1D NOESY NMR spectroscopy. Parikh-Doering ${ }^{32}$ oxidation of alcohol 6, followed by Pinnick ${ }^{33}$ oxidation, produced carboxylic acid $\mathbf{1}$ in excellent yield (Scheme 2).

Enoate $\mathbf{2}$ was envisioned to be synthesized via modification of Marquez's optimized DAG lactone route. ${ }^{34}$ Known epoxy alcohol 7 was accessed by the route reported by Marquez and co-workers. ${ }^{34}$ BOM protection of epoxy alcohol $\mathbf{7}$ gave epoxide $\mathbf{8}$ in moderate yield. Epoxide 8 was treated with lithium acetylide ethylenediamine complex,${ }^{34}$ producing homopropargylic alcohol 9. Lindlar hydrogenation ${ }^{34}$ produced olefin 10 in excellent yield. Hydroboration-oxidation with 9-BBN ${ }^{35}$ gave diol 11 in moderate yield. Parikh-Doering and subsequent Pinnick oxidations gave a mixture of the corresponding $\gamma$-hydroxy acid and lactone 12. This mixture was reacted under Shiina conditions ${ }^{36}$ to give the desired lactone 12 in acceptable yield (Scheme 3).

Even though this route could be used to produce gram quantities of lactone 12, a shorter route was devised using diethyl malonate as a 2-carbon synthon. Ring opening of epoxide $\mathbf{8}$ with the anion of diethyl malonate, followed by subsequent intramolecular cyclization, ${ }^{37}$ produced intermediate lactone $\mathbf{1 3}$ as an uncharacterized mixture of diastereomers. Hydrolysis with $\mathrm{NaOH}$ and subsequent decarboxylation mediated by quinoline $\mathrm{s}^{38}$ at $80{ }^{\circ} \mathrm{C}$ produced lactone 12 in excellent yield, spectroscopically identical with the lactone prepared by the previously described route; double resonance ${ }^{1} \mathrm{H}$ NMR and COSY spectroscopy were used to confirm the identity of the product. This route afforded the desired lactone in four steps from epoxide 8 as compared to seven steps using the modified Marquez route (Scheme $4)$.

Synthesis of enoate $\mathbf{2}$ from $\mathbf{1 2}$ began with the formation of the lithium enolate and aldol reaction with the known aldehyde $14 .{ }^{39}$ This was followed by mesylation of the hydroxyl group and elimination with DBU to give enoate 2 as a 1.2:1 mixture of $Z$ - and $E$-enoates in moderate yield. ${ }^{34}$ All attempts at $Z$-selective Horner-Wadsworth-Emmons (HWE) olefinations failed to deliver usable amounts of the desired product. After separation of the desired $Z$-enoate 2 , the trityl group was selectively removed in the presence of the BOM and 
homoallylic TBS by exposure to a 1:1 mixture of TFA and TFAA at $0{ }^{\circ} \mathrm{C}$, yielding alcohol 15. ${ }^{40}$ Synthesis of the requisite alcohol for Merle 47 involved the removal of the homoallylic TBS of $\mathbf{2}$ using TBAF buffered with $\mathrm{NH}_{4} \mathrm{~F},{ }^{41}$ providing primary alcohol $\mathbf{1 6}$ in good yield (Scheme 5).

Union of carboxylic acid $\mathbf{1}$ and alcohol $\mathbf{1 5}$ was accomplished by the Keck-Boden-modified Steglich esterification, ${ }^{42}$ providing tricyclic ester $\mathbf{1 7}$ in good yield. Deprotection of the $\mathrm{C} 1$ TBDPS in the presence of the C24 TBS under conditions ${ }^{43}$ previously used for other analogues to give alcohol $\mathbf{1 8}$ proved unselective (Scheme 6).

Selective removal of the C26 TBS of $\mathbf{1 7}$ was accomplished using Corey conditions, 3:1:1 $\mathrm{AcOH} / \mathrm{THF} / \mathrm{H}_{2} \mathrm{O} 45^{\circ} \mathrm{C},{ }^{44}$ to give alcohol 19 in acceptable yield. Alcohol 19 was protected as the ethoxyethyl ether. Removal of the C1 TBDPS of acetal $\mathbf{2 0}$ provided $\mathrm{C} 1$ alcohol $\mathbf{2 1}$ in moderate yield. Parikh-Doering and Pinnick oxidations of the $\mathrm{C} 1$ alcohol 21 to the corresponding carboxylic acid $\mathbf{2 2}$ proceeded in good overall yield. Removal of the ethoxyethyl group was accomplished with PPTS in $\mathrm{MeOH}, 45$ affording seco-acid 23 in moderate yield. Yamaguchi macrolactonization of seco-acid $\mathbf{2 3}$ provided macrolactone $\mathbf{2 4}{ }^{46}$ Deprotection of the C3 PMB of $\mathbf{2 4}$ was accomplished with DDQ and finally, the C24 BOM group was removed using Lipshutz conditions, $\mathrm{LiBF}_{4}$ in $\mathrm{MeCN} / \mathrm{H}_{2} \mathrm{O}^{47}$ at $80{ }^{\circ} \mathrm{C}$, to give Merle 46 (Scheme 7).

Synthesis of the reversed analogue Merle 47 commenced with esterification of carboxylic acid 1 with C-ring alcohol 16. In this case, the Keck-Boden-modified Steglich esterification was found to be low yielding, while a modified Yamaguchi esterification ${ }^{48}$ was found to provide tricyclic ester $\mathbf{2 5}$ in somewhat better yields (Scheme 8).

Removal of the C1 TBDPS group of $\mathbf{2 5}$ was accomplished by reaction with HF.pyridine, providing alcohol 26 in good yield. Parikh-Doering and subsequent Pinnick oxidations provided the corresponding carboxylic acid 27 in good overall yield. Deprotection of the trityl group with formic acid in ether ${ }^{49}$ followed by Yamaguchi macrolactonization provided macrolactone 28 in moderate yield. Finally, deprotection of the PMB was effected with DDQ and the BOM group was removed with $\mathrm{LiBF}_{4}$ in $\mathrm{MeCN} / \mathrm{H}_{2} \mathrm{O}$ in low yield, producing analogue Merle 47. The low yield may be attributable to elimination of the $\delta$ ester, resulting in ring opening in the final deprotection step (Scheme 9).

Merle 46 was found to have a binding affinity of $7000 \pm 990 \mathrm{nM}$ for PKCa, which is 4 orders of magnitude less potent than the model compound Merle $23(0.70 \mathrm{nM}$ with $\mathrm{PKC} a)$. This low potency suggests some caution in interpretation of biological effects since the compound may also be having some influence on membrane properties. Evaluation in Toledo leukemia cells, a cell line in which bryostatin 1 and phorbol esters both inhibit proliferation, confirms the large loss of potency for Merle 46 (Figure 4). In the U937 leukemia cells, Merle 46, like PMA, inhibited cell proliferation, albeit only at very high concentrations $(80 \mu \mathrm{M})$. Unlike PMA, Merle 46 failed to induce significant attachment of the U937 cells. This latter result did not indicate that Merle 46 was behaving like bryostatin 1, however, in that the combined treatment of Merle 46 and PMA was similar to that of PMA alone. The most likely conclusion is that Merle 46 is PMA-like but of marginal 
potency in the U937 cells. We cannot exclude that it is even less potent in these cells and that the growth inhibition observed was the result of toxicity.

Merle 47 inhibited PDBu binding to PKC $a$ with a binding affinity of $4940 \pm 470 \mathrm{nM}$ (mean \pm SE), a value approximately similar to that of Merle 46. Biological activity of Merle 47 on the U937 cells was not detected, and only marginal activity was found on the Toledo cells (data not shown), possibly due to its low potency together with the instability of the ester linkage to the $\delta$-carbon of the enoate under biological conditions. The low potency of these two compounds can be attributed at least partially to their reduced lipophilicity. Their $\log P$ value, -0.23 , is much below the optimal range for DAG lactones of $\log P$ of $4-6 .{ }^{27}$ One contributor to the low $\log P$ is the ester linkage to the B-ring and concomitant loss of lipophilic functionality in that region of the structure, relative to the natural bryostatins and previous analogues containing the natural C-ring and a simplified AB-ring system. A potential additional contributor to the loss of affinity might be the disruption of the internal hydrogen-bonding network present in bryostatin and previous analogues due to deletion of the $\mathrm{C} 20$ hemiketal. This hydrogen-bonding network present in the natural product and previous analogues is thought to preorganize and rigidify the structures in conformations that facilitate their binding to PKC.

All of the members of the bryostatin class of natural products contain an $E$-olefin and a bulky gem-dimethyl group on the carbon chain which links the C-ring to the AB-ring system on the left-hand side of the molecule. Reintroduction of this functionality into a DAG lactone bryostatin analogue should increase the lipophilicity and the binding affinity of the resulting ligand for PKC. Such an analogue, Merle 48, could be disconnected via macrolactonization and pyran annulation into the known hydroxyallylsilane $\mathbf{3}$ and aldehyde 29. The C-ring aldehyde $\mathbf{2 9}$ could be derived from aldehyde $\mathbf{3 0}$ and lactone $\mathbf{3 1}$. Aldehyde $\mathbf{3 0}$ could be elaborated from ester $\mathbf{3 2}$ that was previously used for the synthesis of the natural bryostatin C-ring. Lactone $\mathbf{3 1}$ could be produced from previously prepared lactone $\mathbf{1 2}$ (Scheme 10). ${ }^{50}$

A new route to ester $\mathbf{3 2}$ was developed based upon an aldol dehydration sequence starting from methyl isobutyrate. Formation of the lithium enolate of methyl isobutyrate by treatment with LDA at $-78{ }^{\circ} \mathrm{C}$ and subsequent reaction with aldehyde 14 gave hydroxy ester 33 in excellent yield. Mesylation and elimination with DBU at $115^{\circ} \mathrm{C}$ gave ester 32 (Scheme 11).

Reduction of ester 32 with $\mathrm{LiAlH}_{4}$, followed by Parikh-Doering oxidation of the resulting alcohol, provided aldehyde 34 in excellent yield. Wittig olefination of aldehyde 34 produced olefin 35 in good yield. Hydroboration/oxidation of olefin 35 with 9-BBN gave alcohol 36. Parikh-Doering oxidation of $\mathbf{3 6}$ gave aldehyde $\mathbf{3 0}$ in moderate yield. The trityl group of lactone 12 was removed with TFA/TFAA, followed by reprotection of the resulting alcohol $\mathbf{3 7}$ as the TIPS ether to give $\mathbf{3 1}$. Aldol condensation of the lithium enolate of lactone $\mathbf{3 1}$ with aldehyde 30, followed by mesylation-elimination, afforded enoate $\mathbf{3 8}$ as an inseparable mixture of isomers (Scheme 12).

In order to circumvent this selectivity issue, a $Z$-selective HWE olefination was investigated to construct the $Z$-enoate. The lithium enolate of lactone $\mathbf{3 1}$ was reacted with 
diethylchlorophosphate at $-78{ }^{\circ} \mathrm{C}$ in the presence of HMPA; in situ treatment of the Ophosphonate with an excess of LDA provided the C-phosphonate, which was not further characterized. ${ }^{51}$ Treatment with KHMDS in the presence of 18 -crown- 6 at $-78{ }^{\circ} \mathrm{C}$, addition of aldehyde 30, and rapid warming to $\mathrm{rt}$ afforded the kinetic $Z$-enoate $\mathbf{3 8}$ over two steps with 5:1 Z/E-selectivity. ${ }^{52}$ Subsequent deprotection of the TBS group was effected using Corey conditions of $3: 1: 1 \mathrm{AcOH} / \mathrm{THF} / \mathrm{H}_{2} \mathrm{O}, 45^{\circ} \mathrm{C}$, producing alcohol 39 in good yield. Finally, Parikh-Doering oxidation of alcohol $\mathbf{3 9}$ gave the requisite aldehyde $\mathbf{2 9}$ (Scheme 13).

Pyran annulation of $\beta$-hydroxyallylsilane 3 with aldehyde $\mathbf{2 9}$ was conducted with TMSOTf in $\mathrm{Et}_{2} \mathrm{O}$ at $-78^{\circ} \mathrm{C}$, producing bispyran 40 in good overall yield and as a single diastereomer via ${ }^{1} \mathrm{H}$ NMR. One-dimensional ROESY NMR spectroscopy confirmed the desired stereochemistry of the B-ring pyran (Scheme 14).

Deprotection of the TBDPS with HF.pyridine gave alcohol 41, which was processed to afford carboxylic acid $\mathbf{4 2}$ via sequential Parikh-Doering and Pinnick oxidations. Removal of the TIPS group was accomplished by stirring carboxylic acid $\mathbf{4 2}$ with HF.pyridine at rt for 2 days. The resulting seco-acid was cyclized under Yamaguchi conditions to give macrolactone $\mathbf{4 3}$ in low yield over two steps. Removal of the PMB group was accomplished with DDQ, and finally, the BOM group was removed with $\mathrm{LiBF}_{4}$ in $\mathrm{MeCN} / \mathrm{H}_{2} \mathrm{O}$ at $80{ }^{\circ} \mathrm{C}$, providing analogue Merle 48 (Scheme 15).

Merle 48 was found to have a binding affinity of $363 \pm 42 \mathrm{nM}$ (mean \pm SE) toward PKCa, which was a 13-fold increase compared to that with Merle 47. This higher binding affinity of Merle 48 as compared to that of Merles 46 and 47 is consistent with its higher lipophilicity $(\log P=1.94)$, although this $\log P$ is still appreciably lower than optimal for the DAG lactones. Merle 48 was PMA-like in the U937 cells. It inhibited proliferation and induced attachment, which is a pattern of response similar to that of Merle 23. Like PMA, the inhibition of proliferation and the induction of attachment by Merle 48 were both inhibited by bryostatin 1. Like both PMA and bryostatin 1, Merle 48 inhibited the growth of Toledo cells (Figure 5). Its greater binding affinity relative to that of Merle 46 was reflected in its greater potency for the inhibition of the Toledo cell growth. The finding that Merle 48 was PMA-like is consistent with the relatively unfunctionalized nature of the A- and B-rings, which correspond to those of Merle 23, which is PMA-like. ${ }^{14}$

Molecular modeling studies of Merles 46, 47, and 48 indicated that the intramolecular hydrogen-bonding network present in bryostatin 1 and Merle 23 was lost due to the absence of the hemiketal hydroxyl group and the conformational preferences of the molecule differed dramatically as a result (Figure 6). In the energy-minimized conformation, the A- and Brings are nearly perpendicular to each other which has not been observed in previous modeling studies of the bryostatins. ${ }^{20}$ Since the A- and B-rings largely dictate the unique biological activity of the bryostatins, this conformational change raises the concern that, even if properly substituted, the A- and B-rings linked to a C-region binding template that does not preserve the conformation may not function as a bryostatin mimetic.

An energy-minimized conformation of Merle 46 was docked into the $\mathrm{C} 1 \mathrm{~b}$ domain of PKC $\delta$ (Figure 7). This model indicates that the binding domain of the analogue has two 
functionalities that interact with the $\mathrm{Clb}$ domain instead of the three that are seen in bryostatin and the phorbol esters. The diacylglycerol lactone portion of Merle 46 was bound to Thr 242, Leu 251, and Glu 253 as previously seen for bryostatin 1, but the interaction of the macrolactone $\mathrm{C} 25$ oxygen with Gln 257 seen in previous analogues is absent. ${ }^{20}$ The conformation of Merle 46 precludes interaction of the C25 oxygen, which may lessen the binding affinity as compared to bryostatin 1 .

\section{CONCLUSION}

In summary, we have synthesized several bryostatin analogues containing a dramatically simplified C-ring binding domain. Replacement of the natural C-ring of bryostatin for a diacylglycerol lactone using an ester linker to the B-ring produced analogues with low affinity for PKC. Deletion of this ester linkage and reintroduction of the natural olefin and gem-dimethyl group modulated the lipophilicity of the resulting analogue and improved its affinity toward PKC. Modeling studies indicated that the overall conformation of the resulting analogues was altered due to deletion of the intramolecular hydrogen-bonding network present in the natural product. Docking studies with PKC suggest that these analogues bind using just two functionalities instead of three functionalities, as seen in many highly potent PKC ligands. While the first two compounds possessed only marginal biological activity, the derivative incorporating the natural olefin and gem-dimethyl group was shown to be PMA-like, not bryostatin-like, in its activity on U937 cells. This result is consistent with the simplified structure of its A- and B-rings, which corresponds to those of the PMA-like derivative Merle 23. The results from this work provide guidance for the design and synthesis of compounds embodying a similar strategy but with enhanced binding affinities and with more highly functionalized A- and B-rings that may confer bryostatin-like activity.

\section{EXPERIMENTAL SECTION}

\section{General Considerations.}

Diisopropylamine, diisopropylethylamine, pyridine, triethylamine, EtOAc, and $\mathrm{CH}_{2} \mathrm{Cl}_{2}$ were distilled from $\mathrm{CaH}_{2}$. Reagent-grade DMF, DMSO, and acetone were purchased, stored over $4 \AA$ molecular sieves, and used without further purification. $\mathrm{Et}_{2} \mathrm{O}, \mathrm{THF}$, and toluene were distilled from $\mathrm{Na}$ under an atmosphere of $\mathrm{N}_{2}$. $\mathrm{MeOH}$ was distilled from dry $\mathrm{Mg}$ turnings. The titer of $n$-BuLi was determined by the method of Baclawski and Kofron ${ }^{53}$ All other reagents were used without further purification. Yields were calculated for material judged homogeneous by thin layer chromatography and nuclear magnetic resonance (NMR). Thin layer chromatography was performed on Merck Kieselgel 60 A F254 plates or Silicycle 60 A F254 eluting with the solvent indicated, visualized by a $254 \mathrm{~nm}$ UV lamp, and stained with an ethanolic solution of 12-molybdophosphoric acid, a solution of $p$-anisaldehyde in ethanol acidified with sulfuric acid, an aqueous potassium permanganate solution, or a solution of ceric ammonium molybdate, acidified with sulfuric acid. Flash column chromatography was performed with silica gel $40-63 \mu \mathrm{m}$ or silica gel $60-200 \mu \mathrm{m}$ slurry packed with hexanes in glass columns. Glassware for reactions was oven-dried at $125^{\circ} \mathrm{C}$ and cooled under a dry atmosphere prior to use. Liquid reagents and solvents were 
introduced by oven-dried syringes through septum-sealed flasks under a nitrogen atmosphere. Nuclear magnetic resonance spectra were acquired at 300 and $500 \mathrm{MHz}$ for ${ }^{1} \mathrm{H}$ and 75 and $125 \mathrm{MHz}$ for ${ }^{13} \mathrm{C}$. Chemical shifts for proton nuclear magnetic resonance $\left({ }^{1} \mathrm{H}\right.$ NMR) spectra are reported in parts per million relative to the signal of residual $\mathrm{CDCl}_{3}$ at $7.27 \mathrm{ppm}$ or $\left(\mathrm{CH}_{3}\right)_{4} \mathrm{Si}$ at $0.00 \mathrm{ppm}$. Chemicals shifts for carbon nuclear magnetic resonance $\left({ }^{13} \mathrm{C}\right.$ NMR and DEPT) spectra are reported in parts per million relative to the centerline of the $\mathrm{CDCl}_{3}$ triplet at $77.23 \mathrm{ppm}$. Chemical shifts of the unprotonated carbons ("C"') for DEPT spectra were obtained by comparison with the ${ }^{13} \mathrm{C}$ NMR spectrum. The abbreviations $\mathrm{s}, \mathrm{d}$, $\mathrm{dd}$, ddd, dddd, ddddd dt, quint, $\mathrm{t}$, and $\mathrm{m}$ stand for the resonance multiplicity singlet, doublet, doublet of doublets, doublet of doublet of doublets, doublet of doublet of doublet of doublets, doublet of doublet of doublet of doublet of doublets, doublet of triplets, quintet, triplet, and multiplet, respectively. Optical rotations ( $\mathrm{Na} \mathrm{D}$ line) were obtained using a microcell with a $1 \mathrm{dm}$ path length. Specific rotations $[a](\mathrm{deg} \cdot \mathrm{mL} / \mathrm{g} \cdot \mathrm{dm})$ are based on the equation $a=(100 \cdot a) /(l \cdot c)$ and are reported as unitless numbers, where the concentration $c$ is in $\mathrm{g} / 100 \mathrm{~mL}$ and the path length $I$ is in decimeters. Mass spectrometry was performed on a time-of-flight (TOF) high-resolution mass spectrometer. Compounds were named using ChemBioDraw 14.0.0. Biological evaluation of the bryostatin analogues was conducted according to previously published procedures. 54

Bispyran (5).- - To a $25 \mathrm{~mL}$ flask fitted with a stir bar were added silane 3 (262 mg, 0.367 mmol, 1.0 equiv) and aldehyde 4 (319 mg, $1.83 \mathrm{mmol}, 5.0$ equiv). The flask was flushed with $\mathrm{N}_{2}$, and $\mathrm{Et}_{2} \mathrm{O}(10.5 \mathrm{~mL}, 0.035 \mathrm{M})$ was added. After being cooled to $-78{ }^{\circ} \mathrm{C}$, a solution of TMSOTf in $\mathrm{Et}_{2} \mathrm{O}(610 \mu \mathrm{L}$ of $0.9 \mathrm{M}, 0.55 \mathrm{mmol}, 1.5$ equiv) was added dropwise to the stirring solution. After $3 \mathrm{~h}$, the reaction mixture was quenched by dropwise addition of $i$ $\operatorname{Pr}_{2} \mathrm{NEt}(1.0 \mathrm{~mL})$. After $5 \mathrm{~min}$, saturated aqueous $\mathrm{NaHCO}_{3}$ solution $(5.0 \mathrm{~mL})$ was added and the mixture was stirred until it reached rt. The mixture was extracted with EtOAc $(3 \times 10$ $\mathrm{mL})$, and the organic phase was washed with brine $(25 \mathrm{~mL})$ and dried over $\mathrm{Na}_{2} \mathrm{SO}_{4}$, then filtered and concentrated. The crude product was purified using a $3 \times 10 \mathrm{~cm}$ silica gel column, eluting with $4 \%$ EtOAc/hexanes, collecting $10 \mathrm{~mL}$ fractions. Fractions $4-14$ were concentrated to yield the product $(272 \mathrm{mg}, 93 \%)$ as a colorless oil: $\mathrm{Rf}=0.44(10 \% \mathrm{EtOAc} /$ hexanes); ${ }^{1} \mathrm{H}$ NMR (500 MHz, $\left.\mathrm{CDCl}_{3}\right) \delta 7.71-7.68(\mathrm{~m}, 4 \mathrm{H}), 7.46-7.38(\mathrm{~m}, 6 \mathrm{H}), 7.20(\mathrm{~d}, J=$ $9.0 \mathrm{~Hz}, 2 \mathrm{H}), 6.86(\mathrm{~d}, J=8.0 \mathrm{~Hz}, 2 \mathrm{H}), 4.73(\mathrm{dd}, J=8.0,1.5 \mathrm{~Hz}, 2 \mathrm{H}), 4.69$ (d, $J=1.5 \mathrm{~Hz}$, $1 \mathrm{H}), 4.60(\mathrm{~d}, J=1.5 \mathrm{~Hz}, 1 \mathrm{H}), 4.43(\mathrm{ABq}, J=11 \mathrm{~Hz}, \Delta v=30.4 \mathrm{~Hz}, 2 \mathrm{H}), 3.98-3.93(\mathrm{~m}, 1 \mathrm{H})$, $3.85-3.80(\mathrm{~m}, 1 \mathrm{H}), 3.81(\mathrm{~s}, 3 \mathrm{H}), 3.78-3.75(\mathrm{~m}, 1 \mathrm{H}), 3.71(\mathrm{dd}, J=10,5.0 \mathrm{~Hz}, 1 \mathrm{H}), 3.59-3.48$ (m, 4H), 3.40-3.36 (m, 1H), 2.28 (d, $J=13 \mathrm{~Hz}, 3 \mathrm{H}), 2.18$ (d, $J=13.5 \mathrm{~Hz}, 1 \mathrm{H}), 2.03-1.90$ $(\mathrm{m}, 5 \mathrm{H}), 1.86-1.73(\mathrm{~m}, 2 \mathrm{H}), 1.70-1.58(\mathrm{~m}, 3 \mathrm{H}), 1.08(\mathrm{~s}, 9 \mathrm{H}), 0.91(\mathrm{~s}, 9 \mathrm{H}), 0.07$ (d, J= 2.0 $\mathrm{Hz}, 6 \mathrm{H}) ;{ }^{13} \mathrm{C} \mathrm{NMR}\left(125 \mathrm{MHz}, \mathrm{CDCl}_{3}\right) \delta 159.3,145.0,144.4,135.83,135.81,134.1,134.0$ $131.2,129.8,129.6,127.9,127.8,114.0,109.0,108.7,79.0,75.1,75.0,74.9,72.7,72.2$, 66.8, 60.6, 55.5, 43.0, 42.6, 41.5, 41.0, 40.9, 38.1, 37.7, 27.1, 26.2, 19.4, 18.6, -5.0; DEPT $\left(125 \mathrm{MHz}, \mathrm{CDCl}_{3}\right) \mathrm{CH}_{3} \delta 55.5,27.1,26.2,-5.0 ; \mathrm{CH} \delta 109.0,108.7,72.2,66.8,60.6,43.0$, 42.6, 41.5, 41.0, 40.9, 38.1, 37.7; CH $\delta 135.83,135.81,129.8,129.6,127.9,127.8,114.0$, 79.0, 75.1, 75.0, 74.9, 72.7; C $\delta 159.3,145.0,144.4,134.1,134.0,131.2,19.4,18.6$; HRMS (ESI) calcd 821.4609 for $\mathrm{C}_{48} \mathrm{H}_{70} \mathrm{O}_{6} \mathrm{NaSi}_{2}(\mathrm{M}+\mathrm{Na})$, found 821.4614. 
Pyran Alcohol (6).-To a stirring solution of 5 (220 mg, $0.275 \mathrm{mmol}, 1.0$ equiv) in i$\mathrm{PrOH}(6.9 \mathrm{~mL}, 0.04 \mathrm{M})$ contained in a $15 \mathrm{~mL}$ flask under $\mathrm{N}_{2}$ was added $\mathrm{ZrCl}_{4}(32 \mathrm{mg}, 0.14$ mmol, 0.5 equiv). The reaction mixture was stirred at $\mathrm{rt}$ for $60 \mathrm{~h}$. The reaction mixture was quenched with saturated aqueous $\mathrm{NaHCO}_{3}$ solution $(25 \mathrm{~mL})$ and extracted with EtOAc $(3 \times$ $25 \mathrm{~mL}$ ), then washed with brine $(25 \mathrm{~mL})$, dried over $\mathrm{Na}_{2} \mathrm{SO}_{4}$, filtered, and concentrated. The product was purified using a $3 \times 10 \mathrm{~cm}$ silica gel column, eluting with a gradient of 10-30\% EtOAc/hexanes, collecting $10 \mathrm{~mL}$ fractions. Fractions 16-28 were concentrated to yield the product alcohol (132 mg, 70\%) as a colorless oil: $R_{f}=0.58$ (25\% EtOAc/hexanes); ${ }^{1} \mathrm{H}$ NMR $\left(500 \mathrm{MHz}, \mathrm{CDCl}_{3}\right) \delta 7.70-7.76(\mathrm{~m}, 4 \mathrm{H}), 7.45-7.37(\mathrm{~m}, 6 \mathrm{H}), 7.19(\mathrm{~d}, J=8.5 \mathrm{~Hz}, 2 \mathrm{H}), 6.86$ (d, $J=8.5 \mathrm{~Hz}, 2 \mathrm{H}), 4.73(\mathrm{dd}, J=11,2.0 \mathrm{~Hz}, 2 \mathrm{H}), 4.69(\mathrm{~s}, 1 \mathrm{H}), 4.47$ (s, 1H), $4.42(\mathrm{ABq}, J=$ $10.5 \mathrm{~Hz}, \Delta v=41.7 \mathrm{~Hz}, 2 \mathrm{H}), 3.96-3.82(\mathrm{~m}, 1 \mathrm{H}), 3.84-3.80(\mathrm{~m}, 1 \mathrm{H}), 3.81(\mathrm{~s}, 3 \mathrm{H}), 3.77-3.73$ (m, 1H), 3.65-3.63 (m, 1H), 3.60-3.49 (m, 3H), 3.48-3.39 (m, 2H), 2.27 (t, $J=13 \mathrm{~Hz}, 2 \mathrm{H})$, $2.17(\mathrm{~d}, J=13 \mathrm{~Hz}, 1 \mathrm{H}), 2.08$ (q, $J=12 \mathrm{~Hz}, 3 \mathrm{H}), 2.02-1.90(\mathrm{~m}, 4 \mathrm{H}), 1.86-1.73(\mathrm{~m}, 2 \mathrm{H})$, 1.69-1.57 (m, 3H), 1.07 (s, 9H); ${ }^{13} \mathrm{C}$ NMR (125 MHz, $\left.\mathrm{CDCl}_{3}\right) \delta 159.3,144.8,143.7$, 135.83, 135.81 134.1, $134.0131 .2,129.8,129.6,127.9,127.8$ 114.0, 109.5, 108.8, 78.7, 75.2, 75.0, 74.9, 72.6, 72.0, 66.2, 60.6, 55.5, 42.9, 42.5, 41.4, 41.1, 40.8, 37.9, 36.5, 27.1, 19.4; DEPT (125 MHz, $\left.\mathrm{CDCl}_{3}\right) \mathrm{CH}_{3} \delta 55.5,27.1 ; \mathrm{CH}_{2} \delta 109.5,108.8,72.0,66.2,60.6$, $42.9,42.5,41.4,41.1,40.8,37.9,36.5$; CH $\delta 135.8,129.8,129.6,127.8,114.0,78.7,75.2$, 75.0, 74.9, 72.6; C $\delta 159.3,144.8,143.7,134.1,131.2,19.4$; IR 3456, 3072, 2935, 2857, $1652,1613,1514,1471,1428,1362,1303,1248,1174,1106,1036,891,823,738,703 \mathrm{~cm}$ ${ }^{-1}$; HRMS (ESI) calcd 707.3744 for $\mathrm{C}_{42} \mathrm{H}_{56} \mathrm{O}_{6} \mathrm{NaSi}(\mathrm{M}+\mathrm{Na}$ ), found 707.3755.

Acetate Ester (6b).-To a stirring solution of alcohol (6) (36 mg, $0.053 \mathrm{mmol}, 1.0$ equiv) in pyridine $(1.75 \mathrm{~mL}, 0.03 \mathrm{M})$ contained in a $5 \mathrm{~mL}$ flask under $\mathrm{N}_{2}$ was added $\mathrm{Ac}_{2} \mathrm{O}(150 \mu \mathrm{L}$, $1.6 \mathrm{mmol}, 30$ equiv). The reaction mixture was stirred overnight at $\mathrm{rt}$ and quenched with saturated aqueous $\mathrm{NaHCO}_{3}$ solution $(25 \mathrm{~mL})$. The mixture was extracted with EtOAc $(3 \times$ $10 \mathrm{~mL}$ ), dried over $\mathrm{Na}_{2} \mathrm{SO}_{4}$, filtered, and concentrated. The crude product was purified using a $2 \times 10 \mathrm{~cm}$ silica gel column, eluting with $15 \%$ EtOAc/hexanes, collecting $5 \mathrm{~mL}$ fractions. Fractions 6-12 were concentrated to yield the product ( $36 \mathrm{mg}, 92 \%)$ as a colorless oil: $R_{f}=$ 0.76 (50\% EtOAc/hexanes); $[\mathrm{a}]_{\mathrm{D}}{ }^{20}=+3.2\left(c=0.76, \mathrm{CHCl}_{3}\right) ;{ }^{1} \mathrm{H} \mathrm{NMR}\left(500 \mathrm{MHz}, \mathrm{CDCl}_{3}\right)$ $\delta 7.70-7.67(\mathrm{~m}, 4 \mathrm{H}), 7.45-7.37(\mathrm{~m}, 6 \mathrm{H}), 7.19(\mathrm{~d}, J=9.0 \mathrm{~Hz}, 2 \mathrm{H}), 6.86(\mathrm{~d}, J=8.5 \mathrm{~Hz}, 2 \mathrm{H})$, $4.72(\mathrm{~d}, J=10 \mathrm{~Hz}, 2 \mathrm{H}), 4.69(\mathrm{~s}, 1 \mathrm{H}), 4.59(\mathrm{~s}, 1 \mathrm{H}), 4.42(\mathrm{ABq}, J=10.5 \mathrm{~Hz}, \Delta v=37.8 \mathrm{~Hz}$, $2 \mathrm{H}), 4.11(\mathrm{dd}, J=12,6.5 \mathrm{~Hz}, 1 \mathrm{H}), 4.06(\mathrm{dd}, J=12,4.0 \mathrm{~Hz}, 1 \mathrm{H}), 3.94-3.92(\mathrm{~m}, 1 \mathrm{H}), 3.83-$ $3.80(\mathrm{~m}, 1 \mathrm{H}), 3.80(\mathrm{~s}, 3 \mathrm{H}), 3.77-3.74(\mathrm{~m}, 1 \mathrm{H}), 3.57-3.50(\mathrm{~m}, 3 \mathrm{H}), 3.47-3.46(\mathrm{~m}, 1 \mathrm{H}), 2.27$ (t, $J=15.5 \mathrm{~Hz}, 2 \mathrm{H}), 2.17(\mathrm{~d}, J=12.5 \mathrm{~Hz}, 2 \mathrm{H}), 2.06(\mathrm{~s}, 3 \mathrm{H}), 2.02-1.91(\mathrm{~m}, 5 \mathrm{H}), 1.84-1.74$ (m, 2H), 1.67-1.58 (m, 3H), $1.06(\mathrm{~s}, 9 \mathrm{H}) ;{ }^{13} \mathrm{C} \mathrm{NMR}\left(125 \mathrm{MHz}, \mathrm{CDCl}_{3}\right) \delta 171.2,159.4$, 145.0, 143.4, 135.9, 134.1, 131.2, 129.8, 129.6, 127.9, 114.0, 109.8, 108.7, 76.1, 75.3, 75.1, 74.9, 72.7, 72.2, 67.1, 60.6, 55.5, 42.8, 42.5, 41.4, 41.0, 40.4, 38.0, 37.0, 27.2, 21.1, 19.4; DEPT $\left(125 \mathrm{MHz}, \mathrm{CDCl}_{3}\right) \mathrm{CH}_{3} \delta 55.5,27.2,21.1 ; \mathrm{CH}_{2} \delta 109.8,108.7,72.2,67.1,60.6$, $42.8,42.5,41.4,41.0,40.4,38.0,37.0$; CH $\delta 135.9,129.8,129.6,127.9,114.0,76.1,75.3$, $75.1,74.9,72.7$; C $\delta 171.2,159.4,145.0,143.4,134.1,131.2,19.4$; IR (neat) 3071, 2939, 2858, 1740, 1684, 1653, 1558, 1515, 1472, 1428, 1362, 1248, 1111, 1040, 823, $703 \mathrm{~cm}^{-1}$; HRMS (ESI) calcd 749.3850 for $\mathrm{C}_{44} \mathrm{H}_{58} \mathrm{O}_{7} \mathrm{NaSi}(\mathrm{M}+\mathrm{Na}$ ), found 749.3856 . 


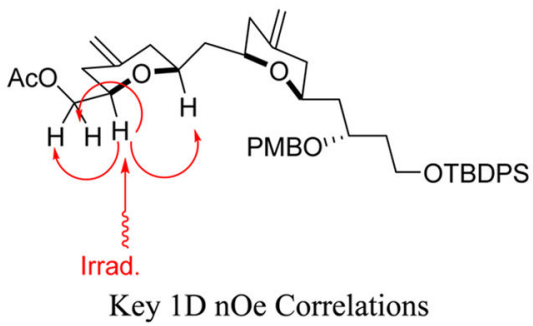

Carboxylic Acid (1).-A solution of alcohol (6) (131 mg, 0.19 mmol, 1.0 equiv) was prepared in $\mathrm{CH}_{2} \mathrm{Cl}_{2}(1.9 \mathrm{~mL}, 0.1 \mathrm{M})$ in a $10 \mathrm{~mL}$ flask under $\mathrm{N}_{2}$. After being cooled to $0{ }^{\circ} \mathrm{C}$, $i$ - $\operatorname{Pr}_{2} \mathrm{NEt}(230 \mu \mathrm{L}, 1.33 \mathrm{mmol}, 7.0$ equiv) was added, followed by DMSO $(140 \mu \mathrm{L}, 1.9 \mathrm{mmol}$, 10 equiv). After $10 \mathrm{~min}, \mathrm{SO}_{3} \cdot \operatorname{Pyr}(121 \mathrm{mg}, 0.76 \mathrm{mmol}, 4.0$ equiv) was added in 4 equal portions over $20 \mathrm{~min}$ to the stirring solution. The reaction mixture was stirred for $1 \mathrm{~h}$ at $0{ }^{\circ} \mathrm{C}$ and then quenched with saturated aqueous $\mathrm{NaHCO}_{3}$ solution $(25 \mathrm{~mL})$, extracted with EtOAc $(3 \times 10 \mathrm{~mL})$, washed with brine $(25 \mathrm{~mL})$, dried over $\mathrm{Na}_{2} \mathrm{SO}_{4}$, filtered, and concentrated. The crude product was purified using a $3 \times 10 \mathrm{~cm}$ silica gel column, collecting $10 \mathrm{~mL}$ fractions. The product containing fractions were concentrated to yield the aldehyde (127 mg, 97\%) which was used immediately for the subsequent oxidation step.

A solution of the previously prepared aldehyde $(127 \mathrm{mg}, 0.190 \mathrm{mmol}, 1.0$ equiv) in $t-\mathrm{BuOH}$ $(2.65 \mathrm{~mL})$ was prepared in a $10 \mathrm{~mL}$ flask, and 2-methyl-2-butene $(2.65 \mathrm{~mL})$ was added, along with an aqueous solution of $\mathrm{KH}_{2} \mathrm{PO}_{4}(1.35 \mathrm{M} .930 \mu \mathrm{L}, 6.0$ equiv) to the stirring solution. The reaction mixture was cooled to $-10{ }^{\circ} \mathrm{C}$, and powdered $80 \% \mathrm{NaClO}_{2}(106 \mathrm{mg}$, 5.0 equiv) was added. The reaction mixture was stirred overnight, allowing the cooling bath to expire. The mixture was then quenched with $\mathrm{pH} 4.0$ acetate buffer $(0.1 \mathrm{M}, 15 \mathrm{~mL})$. After being extracted with EtOAc $(3 \times 10 \mathrm{~mL})$, the organic phase was washed with brine $(25 \mathrm{~mL})$, dried over $\mathrm{Na}_{2} \mathrm{SO}_{4}$, filtered, and concentrated. The product was purified using a $3 \times 10 \mathrm{~cm}$ silica gel column, eluting with a 60:15:1 toluene/EtOAc/AcOH mixture, collecting $5 \mathrm{~mL}$ fractions. Fractions 6-16 were concentrated to yield the carboxylic acid product (119 mg, 92\%) as a colorless oil: $R_{f}=0.21\left(60: 15: 1\right.$ toluene/EtOAc/AcOH); ${ }^{1} \mathrm{H} \mathrm{NMR}(500 \mathrm{MHz}$, $\left.\mathrm{CDCl}_{3}\right) \delta 7.71-7.68(\mathrm{~m}, 4 \mathrm{H}), 7.46-7.38(\mathrm{~m}, 6 \mathrm{H}), 7.19(\mathrm{dd}, J=8.5,2.0 \mathrm{~Hz}, 2 \mathrm{H}), 6.86(\mathrm{dd}, J$ $=8.5,2.0 \mathrm{~Hz}, 2 \mathrm{H}), 4.77(\mathrm{~d}, J=21 \mathrm{~Hz}, 2 \mathrm{H}), 4.74(\mathrm{~s}, 1 \mathrm{H}), 4.66(\mathrm{~s}, 1 \mathrm{H}), 4.38(\mathrm{ABq}, J=10.5$ $\mathrm{Hz}, \Delta v=35.6 \mathrm{~Hz}, 2 \mathrm{H}), 3.943 .88(\mathrm{~m}, 2 \mathrm{H}), 3.85-3.79(\mathrm{~m}, 1 \mathrm{H}), 3.81(\mathrm{~s}, 3 \mathrm{H}), 3.78-3.73(\mathrm{~m}$, $1 \mathrm{H}), 3.70-3.65(\mathrm{~m}, 1 \mathrm{H}), 3.56-3.52(\mathrm{~m}, 1 \mathrm{H}), 3.46-3.41(\mathrm{~m}, 1 \mathrm{H}), 2.62(\mathrm{~d}, J=13 \mathrm{~Hz}, 1 \mathrm{H})$, 2.37-2.31 (m, 1H), 2.26-2.17 (m, 3H), 2.08-1.91 (m, 5H), 1.88-1.81 (m, 1H), 1.80-1.73 $(\mathrm{m}, 1 \mathrm{H}), 1.72-1.60(\mathrm{~m}, 3 \mathrm{H}), 1.07(\mathrm{~s}, 9 \mathrm{H}) ;{ }^{13} \mathrm{C}$ NMR $\left(125 \mathrm{MHz}, \mathrm{CDCl}_{3}\right) \delta 173.2,159.3$, 144.4, 141.4, 135.8, 133.99, 133.97, 131.1, 129.8, 129.6, 127.87, 127.85, 114.0, 111.3, 109.1, 76.1, 76.1, 75.1, 74.6, 72.7, 71.9, 60.6, 55.5, 42.6, 42.4, 41.3, 41.1, 39.8, 37.8, 37.2, 27.1, 19.4; HRMS (ESI) calcd 721.3537 for $\mathrm{C}_{42} \mathrm{H}_{54} \mathrm{O}_{7} \mathrm{NaSi}(\mathrm{M}+\mathrm{Na})$, found 721.3553.

Epoxide (8).-A solution of known epoxy alcohol $7^{22}$ (2.01 g, $5.80 \mathrm{mmol}, 1.0$ equiv) was prepared in $\mathrm{CH}_{2} \mathrm{Cl}_{2}(58 \mathrm{~mL}, 0.1 \mathrm{M})$ in a $100 \mathrm{~mL}$ flask equipped with a magnetic stir bar. $i$ $\mathrm{Pr}_{2} \mathrm{NEt}$ ( $2.5 \mathrm{~mL}, 14.5 \mathrm{mmol}, 2.5$ equiv) was added, followed by BOM-Cl $(1.80 \mathrm{~mL}, 13.3$ $\mathrm{mmol}, 2.3$ equiv) to the stirring solution. After being stirred overnight, the mixture was quenched with saturated aqueous $\mathrm{NaHCO}_{3}$ solution $(60 \mathrm{~mL})$ and extracted with $\mathrm{CH}_{2} \mathrm{Cl}_{2}(3 \times$ $25 \mathrm{~mL})$. The combined organic phases were washed with brine $(60 \mathrm{~mL})$, dried over $\mathrm{MgSO}_{4}$, 
filtered, and concentrated. The product was purified using a $5 \times 20 \mathrm{~cm}$ silica gel column using 10\% EtOAc/hexanes, collecting $30 \mathrm{~mL}$ fractions. Fractions 18-32 were combined and concentrated, yielding an oil that crystallized upon chilling overnight in a $-20{ }^{\circ} \mathrm{C}$ freezer $(2.0 \mathrm{~g}, 75 \%): R_{f}=0.47\left(25 \%\right.$ EtOAc/hexanes); $[a]_{\mathrm{D}}{ }^{20}=-8.04\left(c=3.65, \mathrm{CHCl}_{3}\right) ; \mathrm{mp}: 75-$ $86{ }^{\circ} \mathrm{C} ;{ }^{1} \mathrm{H}$ NMR $\left(300 \mathrm{MHz}, \mathrm{CDCl}_{3}\right) \delta 7.47-7.41(\mathrm{~m}, 6 \mathrm{H}), 7.36-7.19(\mathrm{~m}, 14 \mathrm{H}), 4.71(\mathrm{~s}, 2 \mathrm{H})$, $4.51(\mathrm{~s}, 2 \mathrm{H}), 3.83(\mathrm{ABq}, J=11.4 \mathrm{~Hz}, \Delta v=9.75 \mathrm{~Hz}, 2 \mathrm{H}), 3.29$ (q, $J=10.5 \mathrm{~Hz}, 2 \mathrm{H}), 2.78$ $(\mathrm{dd}, J=15,4.8 \mathrm{~Hz}, 2 \mathrm{H}) ;{ }^{13} \mathrm{C} \mathrm{NMR}\left(75 \mathrm{MHz}, \mathrm{CDCl}_{3}\right) \delta 143.9,137.8,128.9,128.6,128.2$, 128.1, 127.9, 127.3, 94.9, 86.9, 69.6, 68.0, 64.1, 58.1, 49.4; DEPT (125 MHz, $\left.\mathrm{CDCl}_{3}\right) \mathrm{CH}_{3}$ $\delta$ CH $\delta 94.9,69.6,68.0,64.1,49.4$; CH $\delta 128.9,128.6,128.2,128.1,127.9,127.3 ; \mathrm{C} \delta$ 143.9, 137.8, 86.9, 58.1; IR (neat) 3060, 3031, 2932, 2880, 1597, 1491, 1449, 1213, 1166 , 1104, 1073, 1048, 900, 747, 703, $631 \mathrm{~cm}^{-1}$; HRMS (ESI) calcd 489.2042 for $\mathrm{C}_{31} \mathrm{H}_{30} \mathrm{O}_{4} \mathrm{Na}$ $(\mathrm{M}+\mathrm{Na})$, found 489.2047 .

Homopropargylic Alcohol (9).—A solution of epoxide 8 (2.7 g, 5.8 mmol, 1.0 equiv) was prepared in DMSO $(14 \mathrm{~mL})$ in a $50 \mathrm{~mL}$ flask under $\mathrm{N}_{2}$. Lithium acetylide ethylenediamine complex (1.34 g, $14.5 \mathrm{mmol}, 2.5$ equiv) was weighed out in a drybox and transferred to the stirring solution of the epoxide. After $2 \mathrm{~h}$, the solution was cooled in an ice bath and slowly quenched by the addition of saturated aqueous $\mathrm{NH}_{4} \mathrm{Cl}$ solution $(25 \mathrm{~mL})$. The solution was then extracted with $\mathrm{CH}_{2} \mathrm{Cl}_{2}(3 \times 25 \mathrm{~mL})$. The organic phase was then dried over $\mathrm{MgSO}_{4}$, filtered, and concentrated. The product was dissolved in the minimum amount of $\mathrm{CHCl}_{3}$ and purified using a $5 \times 20 \mathrm{~cm}$ silica gel column, eluting with $10 \% \mathrm{EtOAc/}$ hexanes, collecting $30 \mathrm{~mL}$ fractions. Fractions 10-38 were concentrated yielding the product $(2.5 \mathrm{~g}, 88 \%)$ as a colorless oil: $R_{f}=0.26,(25 \% \mathrm{EtOAc} / \mathrm{hexane}) ;[a]_{\mathrm{D}}{ }^{20}=-5.55(c=12.2$, $\left.\mathrm{CHCl}_{3}\right) ;{ }^{1} \mathrm{H}$ NMR $\left(300 \mathrm{MHz}, \mathrm{CDCl}_{3}\right) \delta 7.47-7.41(\mathrm{~m}, 6 \mathrm{H}), 7.34-7.20(\mathrm{~m}, 14 \mathrm{H}), 4.72(\mathrm{~s}$, $2 \mathrm{H}), 4.53(\mathrm{~s}, 2 \mathrm{H}), 3.73(\mathrm{ABq}, J=10.2 \mathrm{~Hz}, \Delta v=8.8 \mathrm{~Hz}, 2 \mathrm{H}), 3.24(\mathrm{~s}, 2 \mathrm{H}), 2.74(\mathrm{~s}, 1 \mathrm{H}), 2.60$ $(\mathrm{d}, J=2.4 \mathrm{~Hz}, 2 \mathrm{H}), 1.95(\mathrm{t}, J=2.4 \mathrm{~Hz}, 1 \mathrm{H}) ;{ }^{13} \mathrm{C} \mathrm{NMR}\left(75 \mathrm{MHz}, \mathrm{CDCl}_{3}\right) \delta 143.8,137.7$, 128.9, 128.6, 128.1, 128.0, 128.0, 127.3, 95.3, 86.9, 80.0, 73.4, 71.3, 71.3, 69.7, 65.4, 25.7; DEPT $\left(125 \mathrm{MHz}, \mathrm{CDCl}_{3}\right) \mathrm{CH}_{3} \delta \mathrm{CH}_{2} \delta 95.4,71.4,69.8,65.5,25.8 ; \mathrm{CH} \delta 129.0,128.7$, 128.2, 128.1, 128.0, 127.4; C $\delta 143.8,137.7,86.9,80.0,73.4,71.3$; IR (neat) 3556,3454 , 3295, 3060, 3031, 2936, 2881, 2119, 1597, 1492, 1449, 1047, 991, 903, 767, 746, 702, 633 $\mathrm{cm}^{-1}$; HRMS (ESI) calcd 515.2198 for $\mathrm{C}_{33} \mathrm{H}_{32} \mathrm{O}_{4} \mathrm{Na}(\mathrm{m}+\mathrm{Na})$, found 515.2202.

Homoallylic Alcohol (10).-A solution of homopropargylic alcohol $9(1.99 \mathrm{~g}, 4.0 \mathrm{mmol}$, 1.0 equiv) was prepared in $50 \%$ EtOAc/hexanes $(35 \mathrm{~mL})$ in a $100 \mathrm{~mL}$ three-neck flask. The center neck of the flask was fitted with a valve connected to a balloon filled with $\mathrm{H}_{2}$. The other two necks were closed with rubber septa. Lindlar's catalyst containing 5\% Pd (0.90 g) and quinoline ( $0.84 \mathrm{~mL}, 7.3 \mathrm{mmol}, 1.8$ equiv) were then added, and the flask was flushed with $\mathrm{H}_{2}$. The reaction was complete by TLC after $2 \mathrm{~h}$ of stirring. The mixture was filtered through a $3 \times 2 \mathrm{~cm}$ bed of Celite and concentrated. The crude product was purified using a 3 $\times 20 \mathrm{~cm}$ silica gel column, eluting with $10 \%$ EtOAc/hexanes, collecting $10 \mathrm{~mL}$ fractions. Fractions $12-30$ were concentrated, yielding the product $(1.91 \mathrm{~g}, 96 \%)$ as a colorless oil: $R_{f}$ $=0.33(25 \%$ EtOAc/hexanes $) ;[a]_{\mathrm{D}}{ }^{20}=-2.5\left(c=0.96, \mathrm{CDCl}_{3}\right) ;{ }^{1} \mathrm{H} \mathrm{NMR}(300 \mathrm{MHz}$, $\left.\mathrm{CDCl}_{3}\right) \delta 7.46-7.41(\mathrm{~m}, 6 \mathrm{H}), 7.36-7.19(\mathrm{~m}, 14 \mathrm{H}), 5.72(\mathrm{dddd}, J=14.7,9.9,7.2,7.2 \mathrm{~Hz}$, 1H), 5.08-5.02 (m, 1H), 5.02-4.95 (m, 1H), $4.72(\mathrm{~s}, 2 \mathrm{H}), 4.53(\mathrm{~s}, 2 \mathrm{H}), 3.65$ (ABq, $J=9.9$ $\mathrm{Hz}, \Delta v=33.7 \mathrm{~Hz}, 2 \mathrm{H}), 3.12(\mathrm{~s}, 2 \mathrm{H}), 2.58(\mathrm{~s}, 1 \mathrm{H}), 2.38(\mathrm{~d}, J=7.2 \mathrm{~Hz}, 2 \mathrm{H}) ;{ }^{13} \mathrm{C}$ NMR $(75$ 
$\left.\mathrm{MHz}, \mathrm{CDCl}_{3}\right) \delta 143.9,137.7,133.2,128.9,128.7,128.1,128.0,127.3,118.7,95.4,86.8$, 73.6, 72.2, 69.7, 65.7, 39.6; DEPT (125 MHz, $\left.\mathrm{CDCl}_{3}\right) \mathrm{CH}_{3} \delta \mathrm{CH}_{2} \delta$ 118.7, 95.4, 72.2. 69.7, 65.7, 39.6; CH $\delta 133.2,128.9,128.7,128.1,128.0,127.3$; C $\delta 143.9,137.7,86.8,73.6$; IR (neat) $3563,3456,3062,3030,2935,2880,1641,1597,1492,1449,1046,701 \mathrm{~cm}^{-1}$; HRMS (ESI) calcd 517.2355 for $\mathrm{C}_{33} \mathrm{H}_{34} \mathrm{O}_{4} \mathrm{Na}(\mathrm{M}+\mathrm{Na})$, found 517.2350.

Diol (11).-A solution of homoallylic alcohol 10 (1.91 g, $3.86 \mathrm{mmol}, 1.0$ equiv) was prepared in THF $(19 \mathrm{~mL})$ in a $100 \mathrm{~mL}$ flask under $\mathrm{N}_{2}$ with stirring. A solution of 9-BBN (0.5 M, $19.0 \mathrm{~mL}, 11.6 \mathrm{mmol}, 3.0$ equiv) was added, and the mixture was stirred for $15 \mathrm{~min}$. The mixture was then placed in an ultrasonic bath for $1 \mathrm{~h}$, after which time no further conversion to product was noticeable via TLC. The mixture was chilled in an ice bath, and aqueous $\mathrm{NaOH}(2.0 \mathrm{M}, 10 \mathrm{~mL})$ was carefully added. Aqueous $\mathrm{H}_{2} \mathrm{O}_{2}(30 \%, 5.0 \mathrm{~mL})$ was then carefully added in small portions to prevent loss of the reaction mixture due to the exothermic nature of the oxidation of the organoborane. After being stirred for $1 \mathrm{~h} \mathrm{at} \mathrm{rt}$, the mixture was extracted with EtOAc $(3 \times 30 \mathrm{~mL})$ and then washed with brine $(50 \mathrm{~mL})$. The organic phase was then dried over $\mathrm{MgSO}_{4}$, filtered, and concentrated. The product was then purified using a $5 \times 20 \mathrm{~cm}$ silica gel column, eluting with a $10-35 \%$ gradient of EtOAc/ hexanes, collecting $10 \mathrm{~mL}$ fractions. Fractions $96-120$ were combined and concentrated to yield the product $(1.61 \mathrm{~g}, 81 \%)$ as a viscous oil: $R_{f}=0.28(25 \% \mathrm{EtOAc} / \mathrm{hexanes}) ;[a]_{\mathrm{D}}{ }^{20}=$ $-2.2\left(c=2.1, \mathrm{CDCl}_{3}\right) ;{ }^{1} \mathrm{H} \mathrm{NMR}\left(300 \mathrm{MHz}, \mathrm{CDCl}_{3}\right) \delta 7.44-7.41(\mathrm{~m}, 6 \mathrm{H}), 7.32-7.21(\mathrm{~m}$, $14 \mathrm{H}), 4.72(\mathrm{~s}, 2 \mathrm{H}), 4.53(\mathrm{~s}, 2 \mathrm{H}) 3.69(\mathrm{ABq}, J=9.9 \mathrm{~Hz}, \Delta v=46.5 \mathrm{~Hz}, 2 \mathrm{H}), 3.69(\mathrm{t}, J=6.0$ $\mathrm{Hz}, 2 \mathrm{H}), 3.14$ (dd, $J=12.9,8.5 \mathrm{~Hz}, 2 \mathrm{H}), 2.96(\mathrm{~s}, 1 \mathrm{H}), 2.19(\mathrm{~s}, 1 \mathrm{H}), 1.70-1.61(\mathrm{~m}, 2 \mathrm{H}), 1.53-$ $1.45(\mathrm{~m}, 2 \mathrm{H}) ;{ }^{13} \mathrm{C}$ NMR $\left(75 \mathrm{MHz}, \mathrm{CDCl}_{3}\right) \delta 143.9,137.7,128.9,128.7,128.1,128.0,128.0$, 127.3, 95.5, 86.8, 73.6, 72.4, 69.8, 65.4, 63.4, 31.5, 26.2; DEPT (125 MHz, $\left.\mathrm{CDCl}_{3}\right) \mathrm{CH}_{3} \delta$ $\mathrm{CH}_{2} \delta 95.5,72.4,69.8,65.4,63.4,31.5,26.2$; $\mathrm{CH} \delta 129.0,128.7,128.1,128.1,128.0$, 127.3; C $\delta 143.9,137.7,86.8,73.6$; IR (neat) 3387, 3086, 3060, 2934, 2878, 1597, 1491, $1449,1049,746,701 \mathrm{~cm}^{-1}$; HRMS (ESI) calcd 535.2498 for $\mathrm{C}_{33} \mathrm{H}_{36} \mathrm{O}_{5} \mathrm{Na}(\mathrm{M}+\mathrm{Na})$, found 535.2450 .

Lactone (12).-A solution of diol 11 (1.32 g $2.58 \mathrm{mmol}, 1.0$ equiv) was prepared in $\mathrm{CH}_{2} \mathrm{Cl}_{2}(26 \mathrm{~mL})$ in a $100 \mathrm{~mL}$ flask fitted with a magnetic stir bar and septum under $\mathrm{N}_{2}$. After being chilled to $0{ }^{\circ} \mathrm{C}, i$-Pr 2 NEt $(3.20 \mathrm{~mL}, 18.1 \mathrm{mmol}, 7.0$ equiv) and DMSO $(1.80 \mathrm{~mL}$, $25.8 \mathrm{mmol}, 10.0$ equiv) were added to the stirred solution. $\mathrm{SO}_{3} \cdot \operatorname{Pyr}(1.65 \mathrm{~g}, 10.3 \mathrm{mmol}, 4.0$ equiv) was added in 4 portions over $20 \mathrm{~min}$. After $1 \mathrm{~h}$, the reaction mixture was quenched by the addition of saturated aqueous $\mathrm{NaHCO}_{3}$ solution $(50 \mathrm{~mL})$ and extracted with $\mathrm{CH}_{2} \mathrm{Cl}_{2}(3 \times$ $25 \mathrm{~mL}$ ). The combined organic phases were washed with brine $(50 \mathrm{~mL})$, dried over $\mathrm{MgSO}_{4}$, filtered, and concentrated to yield a yellow colored oil that was used in the next step without purification.

A solution of the crude aldehyde and hemiacetal from the previous step was prepared in $t$ $\mathrm{BuOH}(36 \mathrm{~mL})$ in a $250 \mathrm{~mL}$ flask, 2-methyl-2-butene $(36 \mathrm{~mL})$ was added, along with an aqueous solution of $\mathrm{KH}_{2} \mathrm{PO}_{4}(1.25 \mathrm{M}, 12.4 \mathrm{~mL})$. After being cooled to $-10{ }^{\circ} \mathrm{C}, \mathrm{NaClO}_{2}$ $(80 \%, 1.45 \mathrm{~g}, 16.1 \mathrm{mmol}, 5.0$ equiv) was added in 4 portions over $20 \mathrm{~min}$. The reaction mixture was then allowed to warm to rt overnight. The reaction mixture was then extracted with $\mathrm{Et}_{2} \mathrm{O}(3 \times 25 \mathrm{~mL})$, and the combined organic phases were washed with brine $(50 \mathrm{~mL})$. 
The organic phase was then dried over $\mathrm{MgSO}_{4}$, filtered, and concentrated to yield the crude carboxylic acid as a viscous yellow oil. The product was purified using a $2.5 \times 15 \mathrm{~cm}$ silica gel column, eluting with $3 \% \mathrm{MeOH} / \mathrm{CH}_{2} \mathrm{Cl}_{2}$, collecting $10 \mathrm{~mL}$ fractions. Fractions $22-48$ contained a mixture of the carboxylic acid and the desired lactone and were concentrated to yield an oil which was used in the subsequent step without characterization $(1.08 \mathrm{~g}, 80 \%$, two steps).

The crude product from the previous step $(0.20 \mathrm{~g}, 0.38 \mathrm{mmol}, 1.0$ equiv) was dissolved in toluene ( $58 \mathrm{~mL}, 0.006 \mathrm{M})$ in a $100 \mathrm{~mL}$ flask. DMAP $(0.27 \mathrm{~g}, 2.2 \mathrm{mmol}, 6.1$ equiv) was added, followed by the slow addition of benzoyl chloride ( $60 \mu \mathrm{L}, 0.5 \mathrm{mmol}, 1.3$ equiv). The reaction mixture was then quenched with saturated aqueous $\mathrm{NaHCO}_{3}$ solution $(10 \mathrm{~mL})$ after being stirred overnight. After the organic phase was separated, the aqueous phase was extracted with EtOAc $(3 \times 10 \mathrm{~mL})$. The combined organic phases were washed with brine $(10 \mathrm{~mL})$ and dried over $\mathrm{MgSO}_{4}$. The mixture was filtered and the solvent removed. The product was purified using a $2.5 \times 20 \mathrm{~cm}$ silica gel column, eluting with a gradient from 10 $75 \%$ EtOAc/hexanes, collecting $5 \mathrm{~mL}$ fractions. Fractions $28-38$ were concentrated to yield the product $(0.15 \mathrm{~g}, 79 \%)$ as a viscous oil: $R_{f}=0.65(50 \% \mathrm{EtOAc} / \mathrm{hexanes}) ;[a]_{\mathrm{D}}{ }^{20}=+6.6$ $\left(c=4.6, \mathrm{CHCl}_{3}\right) ;{ }^{1} \mathrm{H}$ NMR $\left(500 \mathrm{MHz}, \mathrm{CDCl}_{3}\right) \delta 7.44-7.33(\mathrm{~m}, 6 \mathrm{H}), 7.36-7.24(\mathrm{~m}, 14 \mathrm{H})$, $4.73(\mathrm{~s}, 2 \mathrm{H}), 4.55$ (s, 2H), $3.71(\mathrm{ABq}, J=10.0 \mathrm{~Hz}, \Delta v=59.6 \mathrm{~Hz}, 2 \mathrm{H}), 3.24(\mathrm{ABq}, J=10.0$ $\mathrm{Hz}, \Delta v=62.2 \mathrm{~Hz}, 2 \mathrm{H}), 2.64(\mathrm{t}, J=9.0 \mathrm{~Hz}, 2 \mathrm{H}), 2.15-2.00(\mathrm{~m}, 2 \mathrm{H}) ;{ }^{13} \mathrm{C}$ NMR $(125 \mathrm{MHz}$, $\left.\mathrm{CDCl}_{3}\right) \delta 177.3,143.6,137.7,128.9,128.7,128.19,128.17,128.0,127.4,95.1,87.3,86.7$, 70.9, 69.9, 66.4, 29.4, 26.8; DEPT (125 MHz, $\mathrm{CDCl}_{3} \mathrm{CH}_{3} \delta \mathrm{CH}_{2} \delta 95.0,70.8,69.9,66.4$, $29.4,26.8$; CH $\delta 128.9,128.7,128.2,128.18,128.0,127.5$; C $\delta 177.3,143.6,137.7,87.3$, 86.7; IR (neat) 3060, 3031, 2938, 2879, 1779, 1597, 1492, 1450, 1414, 1381, 1048, 747, 704, $634 \mathrm{~cm}^{-1}$; HRMS (ESI) calcd 531.2147 for $\mathrm{C}_{33} \mathrm{H}_{32} \mathrm{O}_{5} \mathrm{Na}(\mathrm{M}+\mathrm{Na})$, found 531.2148.

Diester (13).-To a $500 \mathrm{~mL}$ flask containing EtOH $(190 \mathrm{~mL}, 0.1 \mathrm{M})$ and a stir bar under $\mathrm{N}_{2}$ was slowly added $60 \% \mathrm{NaH}\left(6.84 \mathrm{~g}, 171 \mathrm{mmol}, 9.0\right.$ equiv) at $0{ }^{\circ} \mathrm{C}$. After $20 \mathrm{~min}$, the ice bath was removed and diethyl malonate $(29 \mathrm{~mL}, 190 \mathrm{mmol}, 10.0$ equiv) was added. After being stirred for $30 \mathrm{~min}$ at rt, a solution of epoxide $8(8.90 \mathrm{~g}, 19.0 \mathrm{mmol}, 1.0$ equiv) in THF $(30 \mathrm{~mL})$ was added via cannula; THF $(20 \mathrm{~mL})$ was used to complete the transfer. After being stirred for 8 days at $\mathrm{rt}$, the reaction was quenched with saturated aqueous $\mathrm{NH}_{4} \mathrm{Cl}$ solution (250 mL) and diluted with $\mathrm{H}_{2} \mathrm{O}(200 \mathrm{~mL})$. The solution was then extracted with $50 \%$ EtOAc/hexanes $(3 \times 100 \mathrm{~mL})$, washed with brine $(2 \times 100 \mathrm{~mL})$, dried over $\mathrm{Na}_{2} \mathrm{SO}_{4}$, filtered, and concentrated. The crude product was then purified on a $5 \times 20 \mathrm{~cm}$ silica gel column, eluting with $15 \%$ EtOAc/hexanes, collecting $30 \mathrm{~mL}$ fractions. Fractions $18-82$ contained the product as well as diethyl malonate. The product was heated under high vacuum $0.05 \mathrm{mmHg}$ to remove the remaining diethyl malonate, yielding the product as a mixture of two diastereomers $(9.87 \mathrm{~g}, 89 \%)$ as a light yellow oil that was used without characterization.

A solution of diester 13 ( $3.0 \mathrm{~g}, 5.2 \mathrm{mmol}, 1.0$ equiv) was prepared in EtOH (52 mL, $0.1 \mathrm{M})$ in a $100 \mathrm{~mL}$ flask. To the stirred solution was added aqueous $\mathrm{NaOH}(1.0 \mathrm{M}, 12.9 \mathrm{~mL}, 12.9$ mmol, 2.5 equiv). After being stirred for $24 \mathrm{~h}$, the solution was concentrated and then quenched with a solution of $\mathrm{AcOH}(2.0 \mathrm{~mL})$ in brine $(50 \mathrm{~mL})$. The solution was then extracted with EtOAc $(3 \times 25 \mathrm{~mL})$, washed with brine $(50 \mathrm{~mL})$, dried over $\mathrm{Na}_{2} \mathrm{SO}_{4}$, filtered, 
concentrated, and evaporated with toluene to remove any remaining $\mathrm{AcOH}$. The crude carboxylic acid was used as is $(2.82 \mathrm{~g}, 99 \%)$.

To a stirring solution of the previously produced carboxylic acid $(2.82 \mathrm{~g}, 5.1 \mathrm{mmol}, 1.0$ equiv) in toluene $(102 \mathrm{~mL}, 0.05 \mathrm{M})$ in a $250 \mathrm{~mL}$ flask was added quinoline $(730 \mu \mathrm{L}, 6.1$ mmol, 1.2 equiv). A reflux condenser was attached, and the mixture was flushed with $\mathrm{N}_{2}$ and heated at $80^{\circ} \mathrm{C}$ overnight. After being cooled to rt, the solution was washed with aqueous $\mathrm{HCl}(1.0 \mathrm{M}, 2 \times 50 \mathrm{~mL})$, saturated aqueous $\mathrm{NaHCO}_{3}$ solution $(100 \mathrm{~mL})$, brine $(100$ $\mathrm{mL}$ ), and dried over $\mathrm{Na}_{2} \mathrm{SO}_{4}$. After filtration and concentration, the product was purified using a $3 \times 15 \mathrm{~cm}$ silica gel column, eluting with $25 \%$ EtOAc/hexanes, collecting $10 \mathrm{~mL}$ fractions. Fractions 8-24 were combined and concentrated to yield the product ( $2.33 \mathrm{~g}$, 90\%) as a colorless oil: ${ }^{1} \mathrm{H}$ NMR $\left(500 \mathrm{MHz}, \mathrm{CDCl}_{3}\right) \delta 7.46-7.39(\mathrm{~m}, 6 \mathrm{H}), 7.36-7.22(\mathrm{~m}$, $14 \mathrm{H}), 4.73(\mathrm{~s}, 2 \mathrm{H}), 4.54(\mathrm{~s}, 2 \mathrm{H}), 3.71(\mathrm{ABq}, J=10.0 \mathrm{~Hz}, \Delta v=59.4 \mathrm{~Hz}, 2 \mathrm{H}), 3.25(\mathrm{ABq}, J=$ $10.0 \mathrm{~Hz}, \Delta v=62.2 \mathrm{~Hz}, 2 \mathrm{H}), 2.64(\mathrm{t}, J=8.5 \mathrm{~Hz}, 2 \mathrm{H}), 2.13-1.99(\mathrm{~m}, 2 \mathrm{H}) ;{ }^{13} \mathrm{C}$ NMR $(125$ $\left.\mathrm{MHz}, \mathrm{CDCl}_{3}\right) \delta 177.3,143.5,137.7,128.8,128.7,128.18,128.15,128.0,127.4,95.0,87.3$, $86.7,70.9,69.9,66.4,29.4,26.8$.

Enoate (2).-A $1.0 \mathrm{M}$ solution of LDA in THF was prepared by adding $i-\mathrm{Pr}_{2} \mathrm{NH},(0.77$ $\mathrm{mL}, 5.5 \mathrm{mmol}, 1.1$ equiv) to a $5.0 \mathrm{~mL}$ volumetric flask under $\mathrm{N}_{2}$. The solution was chilled to $-78{ }^{\circ} \mathrm{C}$, and $n$-BuLi $(2.5 \mathrm{M}, 2.0 \mathrm{~mL}, 5.0 \mathrm{mmol}, 1.0$ equiv) was then added dropwise. After 5 min, the mixture was transferred to a $0{ }^{\circ} \mathrm{C}$ bath and THF added to make $5 \mathrm{~mL}$ of solution. THF $(2.0 \mathrm{~mL})$ was added to a $15 \mathrm{~mL}$ flask under $\mathrm{N}_{2}$, which was chilled to $-78{ }^{\circ} \mathrm{C}$, and the previously prepared solution of LDA $(1.0 \mathrm{M}, 0.52 \mathrm{~mL}, 0.52 \mathrm{mmol}, 1.1$ equiv) was added. A solution of lactone 12 (238 mg, $0.47 \mathrm{mmol}, 1.0$ equiv) in THF $(1.0 \mathrm{~mL})$ was then added via cannula to the LDA-containing solution; the transfer was completed with THF $(1.7 \mathrm{~mL})$. After being stirred for $45 \mathrm{~min}$ at $-78{ }^{\circ} \mathrm{C}$, a solution of known aldehyde $\mathbf{1 4}(133 \mathrm{mg}, 0.71$ mmol, 1.5 equiv) in THF $(1.0 \mathrm{~mL})$ was added. THF $(1.0 \mathrm{~mL})$ was used to complete the transfer of the aldehyde-containing solution. The reaction mixture was stirred for $2 \mathrm{~h}$, allowing the $-78{ }^{\circ} \mathrm{C}$ bath to expire. The reaction mixture was then quenched with saturated aqueous $\mathrm{NH}_{4} \mathrm{Cl}$ solution $(25 \mathrm{~mL})$, extracted with EtOAc $(3 \times 15 \mathrm{~mL})$, and washed with brine $(50 \mathrm{~mL})$. After being dried over $\mathrm{Na}_{2} \mathrm{SO}_{4}$, the solution was filtered and concentrated. The product was purified using a $2 \times 10 \mathrm{~cm}$ silica gel column, eluting with $25 \%$ EtOAc/hexanes, collecting $5 \mathrm{~mL}$ fractions. Fractions $6-12$ contained the product, which was used as is without further characterization.

The aldol product $(326 \mathrm{mg})$ was taken up in $\mathrm{CH}_{2} \mathrm{Cl}_{2}(4.7 \mathrm{~mL}, 0.1 \mathrm{M})$ contained in a $15 \mathrm{~mL}$ flask under $\mathrm{N}_{2}$. The stirring solution was cooled to $0{ }^{\circ} \mathrm{C}$. $\mathrm{Et}_{3} \mathrm{~N}(200 \mu \mathrm{L}, 1.40 \mathrm{mmol}, 3.0$ equiv) was added to the solution, followed by $\mathrm{MsCl}$ ( $68 \mu \mathrm{L}, 0.75 \mathrm{mmol}, 1.6$ equiv). After being stirred for $10 \mathrm{~min}$, DBU ( $210 \mu \mathrm{L}, 1.40 \mathrm{mmol}, 3.0$ equiv) was added dropwise. After 15 min, all starting material was consumed via TLC; the reaction mixture was then quenched by the addition of a solution of saturated aqueous $\mathrm{NaHCO}_{3}(50 \mathrm{~mL})$. After extraction with $\mathrm{CH}_{2} \mathrm{Cl}_{2}(3 \times 15 \mathrm{~mL})$, the organic phase was washed with brine $(50 \mathrm{~mL})$ and dried over $\mathrm{Na}_{2} \mathrm{SO}_{4}$. The solution was filtered and concentrated, and the resulting oil was purified using a $2 \times 15 \mathrm{~cm}$ silica gel column, eluting with $10 \%$ EtOAc/hexanes, collecting $5.0 \mathrm{~mL}$ fractions. Fractions 12-22 contained the desired $Z$-isomer $(150 \mathrm{mg}, 47 \%)$ as a colorless oil. Fractions $23-38$ contained the $E$-isomer (112 mg, 35\%): $R_{f}=0.64$ (25\% EtOAc/hexanes); 
$[a]_{\mathrm{D}}^{20}=-1.73\left(c=1.62, \mathrm{CHCl}_{3}\right) ;{ }^{1} \mathrm{H}$ NMR $\left(500 \mathrm{MHz}, \mathrm{CDCl}_{3}\right) 7.48-7.46(\mathrm{~m}, 6 \mathrm{H}), 7.36-$ $7.32(\mathrm{~m}, 14 \mathrm{H}), 6.31$ (dddd, $J=9.0,4.0,1.5,1.5 \mathrm{~Hz}, 1 \mathrm{H}), 4.70(\mathrm{~s}, 2 \mathrm{H}), 4.53(\mathrm{~s}, 2 \mathrm{H}) 3.75-$ $3.67(\mathrm{~m}, 4 \mathrm{H}), 3.25(\mathrm{ABq}, J=10 \mathrm{~Hz}, \Delta v=61.2 \mathrm{~Hz}, 2 \mathrm{H}), 3.06-3.01(\mathrm{~m}, 1 \mathrm{H}), 2.97-2.93(\mathrm{~m}$, $1 \mathrm{H}), 2.81(\mathrm{~d}, J=16.5 \mathrm{~Hz}, 1 \mathrm{H}), 2.72(\mathrm{~d}, J=18.5 \mathrm{~Hz}, 1 \mathrm{H}), 0.91(\mathrm{~s}, 9 \mathrm{H}), 0.08(\mathrm{~s}, 6 \mathrm{H}) ;{ }^{13} \mathrm{C}$ NMR (125 MHz, $\left.\mathrm{CDCl}_{3}\right) \delta 169.2,143.6,140.4,137.7,128.8,128.8,128.6,128.1,127.9$, 127.3, 126.3, 94.9, 87.1, 83.0, 70.2, 69.7, 65.9, 62.3, 34.1, 31.4, 26.1, 18.6, -5.1; DEPT (125 $\left.\mathrm{MHz}, \mathrm{CDCl}_{3}\right)_{\mathrm{CH}_{3}} \delta 26.1,-5.1 ; \mathrm{CH}_{2} \delta 94.9,70.2,69.7,65.9,62.3,34.1,31.4 ; \mathrm{CH} \delta 140.4$, $128.8,128.6,128.1,127.9,127.3,126.3 \mathrm{C} \delta 169.2,143.6,137.7,128.8,87.1,83.0,18.6$; IR (neat) 3058, 2953, 2928, 2857, 1758, 1491, 1449, 1363, 1256, 1201, 1178, 1095, 1047, 992, 941, 836, 777, 746, 700, 668, $632 \mathrm{~cm}^{-1}$; HRMS (ESI) calcd 701.3280 for $\mathrm{C}_{42} \mathrm{H}_{50} \mathrm{O}_{6} \mathrm{SiNa}$ $(\mathrm{M}+\mathrm{Na})$, found 701.3284 .

Enoate Alcohol (15).-To a stirring solution of enoate 2 ( $80 \mathrm{mg}, 0.12 \mathrm{mmol}, 1.0$ equiv) in $\mathrm{CH}_{2} \mathrm{Cl}_{2}(2.4 \mathrm{~mL}, 0.05 \mathrm{M})$ at $0{ }^{\circ} \mathrm{C}$ was added a 50:50 TFA/TFAA solution in $\mathrm{CH}_{2} \mathrm{Cl}_{2}(0.5 \mathrm{M}$, $720 \mu \mathrm{L}, 0.36 \mathrm{mmol}, 3.0$ equiv). The reaction mixture turned bright yellow and was stirred at $0{ }^{\circ} \mathrm{C}$ for $45 \mathrm{~min}$. The reaction mixture was quenched with $\mathrm{Et}_{3} \mathrm{~N}(0.34 \mathrm{~mL}, 2.4 \mathrm{mmol}, 20$ equiv). After $5 \mathrm{~min}$, the mixture was evaporated with methanol $(3 \times 25 \mathrm{~mL})$, followed by toluene $(10 \mathrm{~mL})$. The product was purified using a $2 \times 13 \mathrm{~cm}$ silica gel column, eluting with $25 \%$ EtOAc/hexanes, collecting $5 \mathrm{~mL}$ fractions. Fractions 6-24 were concentrated to yield the product (45.5 mg, $69 \%)$ as a colorless oil: $R_{f}=0.14\left(25 \%\right.$ EtOAc/hexanes); $[a]_{\mathrm{D}}{ }^{20}=$ $-8.1(c=0.61, \mathrm{MeOH}) ;{ }^{1} \mathrm{H}$ NMR $\left(500 \mathrm{MHz}, \mathrm{CDCl}_{3}\right)$ 7.37-7.27 (m, 5H), 6.35 (dddd, $J=$ 9.5, 4.5, 2.0, 2.0 Hz, 1H), 4.77 (s, 2H), 4.60 (s, 2H), 3.75-3.64 (m, 6H), 2.93 (dd, $J=13.5$, $6.0 \mathrm{~Hz}, 2 \mathrm{H}), 2.86-2.76(\mathrm{~m}, 2 \mathrm{H}), 2.25$ (s, $1 \mathrm{H}), 0.90$ (s, 9H), 0.06 (s, 6H); ${ }^{13} \mathrm{C}$ NMR $(125$ $\left.\mathrm{MHz}, \mathrm{CDCl}_{3}\right) \delta 169.2,141.8,137.7,128.7,128.1,128.0,125.7,95.2,83.5,70.0,69.7,65.4$, 62.3, 33.2, 31.4, 26.1, 18.5, 5.1; DEPT (125 MHz, $\left.\mathrm{CDCl}_{3}\right) \mathrm{CH}_{3} \delta 26.1,-5.1 ; \mathrm{CH}_{2} \delta 95.2$, 70.0, 69.7, 65.4, 62.3, 33.2, 31.4; CH $\delta 141.8,128.7,128.1,128.0$; C $\delta 169.2,137.7,125.7$, 83.5, 18.5; IR (neat) 3443, 3033, 2954, 2930, 2885, 2858, 1755, 1672, 1575, 1498, 1472, 1463, 1381, 1364, 1257, 1200, 1177, 1101, 1046, 939, 837, $778 \mathrm{~cm}^{-1}$; HRMS (ESI) calcd 459.2179 for $\mathrm{C}_{23} \mathrm{H}_{36} \mathrm{O}_{6} \mathrm{SiNa}(\mathrm{M}+\mathrm{Na})$, found 459.2181.

Enoate Alcohol (16).-To a solution of enoate $2(150 \mathrm{mg}, 0.22 \mathrm{mmol}, 1.0$ equiv) in THF $(4.40 \mathrm{~mL}, 0.05 \mathrm{M})$ contained in a $15 \mathrm{~mL}$ polyethylene centrifuge tube was added $\mathrm{NH}_{4} \mathrm{~F}(41$ $\mathrm{mg}, 1.1 \mathrm{mmol}, 5.0$ equiv). TBAF (1.0 M, $1.11 \mathrm{~mL}, 1.11 \mathrm{mmol}, 5.0$ equiv) was added. After being stirred for $1.5 \mathrm{~h}$, the reaction mixture was quenched with brine $(20 \mathrm{~mL})$ and extracted with EtOAc $(3 \times 10 \mathrm{~mL})$. The organic phase was dried over $\mathrm{Na}_{2} \mathrm{SO}_{4}$, filtered, and concentrated. The product was purified using a $2 \times 10 \mathrm{~cm}$ silica gel column, eluting with $35 \%$ EtOAc/hexanes, collecting $5 \mathrm{~mL}$ fractions. Fractions $18-44$ were concentrated to yield the product as a colorless oil $(118 \mathrm{mg}, 95 \%): R_{f}=0.40(50 \%$ EtOAc/hexanes $) ;[a]_{\mathrm{D}}{ }^{20}=$ $+0.48\left(c=1.67, \mathrm{CHCl}_{3}\right) ;{ }^{1} \mathrm{H}$ NMR $\left(500 \mathrm{MHz}, \mathrm{CDCl}_{3}\right) \delta 7.44-7.43(\mathrm{~m}, 6 \mathrm{H}), 7.39-7.24(\mathrm{~m}$, $14 \mathrm{H}$ ), 6.28 (dddd, $J=7.5,4.5,2.0,2.0 \mathrm{~Hz}, 1 \mathrm{H}), 4.72(\mathrm{~s}, 2 \mathrm{H}), 4.53(\mathrm{~s}, 2 \mathrm{H}), 3.83-3.74(\mathrm{~m}$, $2 \mathrm{H}), 3.70(\mathrm{q}, J=10 \mathrm{~Hz}, 2 \mathrm{H}), 3.34(\mathrm{~d}, J=9.5 \mathrm{~Hz}, 1 \mathrm{H}), 3.17(\mathrm{~d}, J=11.5 \mathrm{~Hz}, 1 \mathrm{H}), 3.10-3.04$ (m, 1H), 3.00-2.94 (m, 1H), 2.83 (dd, $J=14,2.0 \mathrm{~Hz}, 1 \mathrm{H}), 2.74(\mathrm{dd}, J=16.5,2.0 \mathrm{~Hz}, 1 \mathrm{H})$, $1.78(\mathrm{~s}, 1 \mathrm{H}) ;{ }^{13} \mathrm{C} \mathrm{NMR}\left(125 \mathrm{MHz}, \mathrm{CDCl}_{3}\right) \delta 169.9,143.6,139.4,137.7,128.8,128.6$, 128.1, 128.1, 128.0, 127.7, 127.4, 95.0, 87.2, 83.5, 70.2, 69.8, 65.9, 62.1, 34.2, 31.2; DEPT $\left(125 \mathrm{MHz}, \mathrm{CDCl}_{3}\right) \mathrm{CH}_{3} \delta \mathrm{CH}_{2} \delta 95.0,70.2,69.8,65.9,62.1,34.2,31.2 ; \mathrm{CH} \delta 139.4,128.8$, 
128.6, 128.1, 128.0, 127.4; C $\delta 169.9,143.6,137.7,127.7,87.2,83.5$; IR (neat) 3472, 3087, 2928, 2876, 1754, 1672, 1491, 1449, 1370, 1214, 1172, 1078, 1045, 992, 944, 900, 747, 700 $\mathrm{cm}^{-1}$; HRMS (ESI) calcd 587.2410 for $\mathrm{C}_{36} \mathrm{H}_{36} \mathrm{O}_{6} \mathrm{Na}(\mathrm{M}+\mathrm{Na}$ ), found 587.2420.

Pyran Ester (17).-A stirring solution of carboxylic acid 1 (91 mg, $0.13 \mathrm{mmol}, 1.0$ equiv) and alcohol 15 (68 mg, $0.16 \mathrm{mmol}, 1.2$ equiv) was prepared in $\mathrm{CH}_{2} \mathrm{Cl}_{2}(1.3 \mathrm{~mL}, 0.1 \mathrm{M})$ in a $5 \mathrm{~mL}$ flask under $\mathrm{N}_{2}$. After being cooled to $0{ }^{\circ} \mathrm{C}$, EDCI $\cdot \mathrm{HCl}(100 \mathrm{mg}, 0.52 \mathrm{mmol}, 4.0$ equiv), DMAP (48 mg, $0.39 \mathrm{mmol}, 3.0$ equiv), and DMAP. $\mathrm{HCl}$ (41 mg, $0.26 \mathrm{mmol}, 2.0$ equiv) were then added. After being warmed to rt, the reaction mixture was stirred for $6 \mathrm{~h}$. The reaction mixture was then quenched with saturated aqueous $\mathrm{NaHCO}_{3}$ solution $(25 \mathrm{~mL})$, extracted with $\mathrm{CH}_{2} \mathrm{Cl}_{2}(3 \times 15 \mathrm{~mL})$, washed with brine $(25 \mathrm{~mL})$, and dried over $\mathrm{Na}_{2} \mathrm{SO}_{4}$. After filtration and concentration, the product was purified using a $3 \times 10 \mathrm{~cm}$ silica gel column, eluting with a gradient consisting of $100 \mathrm{~mL}$ of $10 \%$ EtOAc/hexanes, $300 \mathrm{~mL}$ of $25 \%$ EtOAc/hexanes, collecting $10 \mathrm{~mL}$ fractions. Fractions 36-64 were concentrated to yield the product (135 mg, 93\%) as a colorless oil: $R_{f}=0.44\left(25 \%\right.$ EtOAc/hexanes); $[a]_{\mathrm{D}}{ }^{20}=$ $+7.5\left(c=0.85, \mathrm{PhCH}_{3}\right) ;{ }^{1} \mathrm{H}$ NMR $\left(500 \mathrm{MHz}, \mathrm{CDCl}_{3}\right) \delta 7.70-7.68(\mathrm{~m}, 4 \mathrm{H}), 7.45-7.33(\mathrm{~m}$, $11 \mathrm{H}), 7.18(\mathrm{~d}, J=9.0 \mathrm{~Hz}, 2 \mathrm{H}), 6.86(\mathrm{~d}, J=9.0 \mathrm{~Hz}, 2 \mathrm{H}), 6.36(\mathrm{t}, J=7.5 \mathrm{~Hz}, 1 \mathrm{H}), 4.76(\mathrm{~s}$, $2 \mathrm{H}), 4.73(\mathrm{~d}, J=4.0 \mathrm{~Hz}, 2 \mathrm{H}), 4.71(\mathrm{~s}, 1 \mathrm{H}), 4.62(\mathrm{~s}, 1 \mathrm{H}), 4.60(\mathrm{~s}, 2 \mathrm{H}), 4.40(\mathrm{ABq}, J=10.5$ $\mathrm{Hz}, \Delta v=42.7 \mathrm{~Hz}, 2 \mathrm{H}), 4.28(\mathrm{ABq}, J=12 \mathrm{~Hz}, \Delta v=64.9 \mathrm{~Hz}, 2 \mathrm{H}), 3.92(\mathrm{dd}, J=12,2.5 \mathrm{~Hz}$, $2 \mathrm{H}), 3.83-3.79(\mathrm{~m}, 1 \mathrm{H}), 3.80(\mathrm{~s}, 3 \mathrm{H}), 3.77-3.71(\mathrm{~m}, 3 \mathrm{H}), 3.67(\mathrm{dd}, J=15,10 \mathrm{~Hz}, 2 \mathrm{H}), 3.62-$ $3.50(\mathrm{~m}, 2 \mathrm{H}), 3.50-3.42(\mathrm{~m}, 1 \mathrm{H}), 3.06-2.97(\mathrm{~m}, 1 \mathrm{H}), 2.92-2.84(\mathrm{~m}, 1 \mathrm{H}), 2.85(\mathrm{~d}, J=16.5$ $\mathrm{Hz}, 1 \mathrm{H}), 2.75(\mathrm{~d}, J=16.5 \mathrm{~Hz}, 1 \mathrm{H}), 2.44(\mathrm{~d}, J=13.5 \mathrm{~Hz}, 1 \mathrm{H}), 2.30-2.23(\mathrm{~m}, 3 \mathrm{H}), 2.18(\mathrm{t}, J=$ $12 \mathrm{~Hz}, 1 \mathrm{H}), 2.09-1.90$ (m, 4H), 1.86-1.72 (m, 2H), 1.71-1.59 (m, 3H), 1.06 (s, 9H), 0.90 (s, 9H), 0.07 (s, 6H); ${ }^{13} \mathrm{C}$ NMR $\left(125 \mathrm{MHz}, \mathrm{CDCl}_{3}\right) \delta 170.3,168.5,159.3,144.8,142.04$, 142.01, 137.7, 135.8, 134.1, 134.0, 131.2, 129.8, 129.5, 128.7, 128.08, 128.06, 127.87, 127.85, 125.0, 114.0, 110.8, 108.8, 95.2, 81.2, 76.6, 75.6, 75.0, 74.6, 72.8, 72.0, 70.1, 69.6, 66.0, 62.2, 60.6, 55.5, 42.6, 42.5, 41.4, 41.1, 39.9, 37.9, 37.6, 33.8, 31.4, 27.2, 26.1, 19.4, 18.5, -5.1; DEPT (125 MHz, $\mathrm{CDCl}_{3}$ ) $\mathrm{CH}_{3} \delta 55.3,27.2,26.1,-5.1 ; \mathrm{CH}_{2} \delta 110.8,108.8$, 95.2, 72.0, 70.1, 69.6, 66.0, 62.2, 60.6, 42.6, 42.5, 41.4, 41.1, 39.9, 37.9, 37.6, 33.8, 31.4; CH $\delta 170.3,142.1,135.8,129.8,129.5,128.7,128.08,128.06,127.87,127.85,114.0,76.6$, 75.6, 75.0, 74.6, 72.8; C $\delta 168.5,159.3,144.8,142.04,142.01,137.7,134.1,134.0,131.2$, 125.0, 81.2, 19.4, 18.5; IR (neat) 2933, 2857, 1762, 1653, 1612, 1514, 1472, 1429, 1362, 1249, 1173, 1106, 1048, 893, 836, 777, 737, $702 \mathrm{~cm}^{-1}$; HRMS (ESI) calcd for $\mathrm{C}_{65} \mathrm{H}_{88} \mathrm{O}_{12} \mathrm{Si}_{2} \mathrm{Na}(\mathrm{M}+\mathrm{Na}), 1139.5712$ found 1139.5618 .

C24 Alcohol (19).-A solution of 17 (175 $\mathrm{mg}, 0.157 \mathrm{mmol}, 1.0$ equiv) was prepared in 3:1:1 AcOH/THF/ $\mathrm{H}_{2} \mathrm{O}(15.7 \mathrm{~mL}, 0.01 \mathrm{M})$ in a $25 \mathrm{~mL}$ flask. The stirring solution was heated at $45^{\circ} \mathrm{C}$ for $1.5 \mathrm{~h}$, after which the reaction was complete. The reaction mixture was diluted with brine $(100 \mathrm{~mL})$ and extracted with EtOAc $(3 \times 25 \mathrm{~mL})$. After being dried over $\mathrm{Na}_{2} \mathrm{SO}_{4}$ and filtered, the solution was concentrated. The product was purified using a $2 \times 15 \mathrm{~cm}$ silica gel column, eluting with a gradient of 25-50\% EtOAc/hexanes, collecting $5 \mathrm{~mL}$ fractions. Fractions $35-72$ were concentrated to yield the product $(117 \mathrm{mg}, 74 \%)$ as a colorless oil: $R_{f}=0.28\left(50 \%\right.$ EtOAc/hexanes); $[a]_{\mathrm{D}}{ }^{20}=+9.7\left(c=0.57, \mathrm{CH}_{2} \mathrm{Cl}_{2}\right) ;{ }^{1} \mathrm{H} \mathrm{NMR}$ $\left(500 \mathrm{MHz}, \mathrm{CDCl}_{3}\right) \delta 7.70-7.67(\mathrm{~m}, 4 \mathrm{H}), 7.45-7.30(\mathrm{~m}, 11 \mathrm{H}), 7.18(\mathrm{~d}, J=9.0 \mathrm{~Hz}, 2 \mathrm{H}), 6.86$ (d, $J=8.5 \mathrm{~Hz}, 2 \mathrm{H}), 6.33$ (dddd, $J=12,7.5,2.0,2.0 \mathrm{~Hz}, 1 \mathrm{H}), 4.77$ (s, 2H), 4.74-4.72 (m, 
$3 \mathrm{H}), 4.61(\mathrm{~s}, 1 \mathrm{H}), 4.57(\mathrm{~s}, 2 \mathrm{H}), 4.40(\mathrm{ABq}, J=10.5 \mathrm{~Hz}, \Delta v=45.6 \mathrm{~Hz}, 2 \mathrm{H}), 4.30(\mathrm{ABq}, J=$ $12 \mathrm{~Hz}, \Delta v=42 \mathrm{~Hz}, 2 \mathrm{H}), 3.93(\mathrm{dd}, J=11.5,2.0 \mathrm{~Hz}, 1 \mathrm{H}), 3.94-3.88(\mathrm{~m}, 1 \mathrm{H}), 3.84-3.80(\mathrm{~m}$, $1 \mathrm{H}), 3.80(\mathrm{~s}, 3 \mathrm{H}), 3.77-3.72(\mathrm{~m}, 3 \mathrm{H}), 3.68(\mathrm{~s}, 2 \mathrm{H}), 3.61-3.56(\mathrm{~m}, 1 \mathrm{H}), 3.56-3.50(\mathrm{~m}, 1 \mathrm{H})$, $3.49-3.43(\mathrm{~m}, 1 \mathrm{H}), 2.96(\mathrm{dd}, J=13.5,6.5 \mathrm{~Hz}, 2 \mathrm{H}), 2.82(\mathrm{ABq}, J=19 \mathrm{~Hz}, \Delta v=33.9 \mathrm{~Hz}$, $2 \mathrm{H}), 2.43(\mathrm{~d}, J=13.5 \mathrm{~Hz}, 1 \mathrm{H}), 2.31-2.23(\mathrm{~m}, 3 \mathrm{H}), 2.17(\mathrm{~d}, J=13.5 \mathrm{~Hz}, 1 \mathrm{H}), 2.09-2.04(\mathrm{~m}$, 2H), 2.02-1.90 (m, 3H), 1.84-1.74 (m, 2H), 1.69-1.61 (m, 3H), $1.06(\mathrm{~s}, 9 \mathrm{H}) ;{ }^{13} \mathrm{C}$ NMR (125 $\left.\mathrm{MHz}, \mathrm{CDCl}_{3}\right) \delta 170.3,169.0,159.3,144.7,142.0,140.9,137.6,135.8,134.0,133.96,131.1$, $129.8,129.5,128.7,128.1,127.87,127.85,126.3,114.0,110.8,108.9,95.2,81.6,76.6$, 75.6, 75.1, 74.6, 72.8, 72.1, 70.1, 69.6, 66.1, 61.9, 60.6, 55.5, 42.6, 42.4, 41.3, 41.1, 39.8, 37.9, 37.5, 33.9, 31.1, 27.1; DEPT (125 MHz, $\left.\mathrm{CDCl}_{3}\right) \mathrm{CH}_{3} \delta 55.5,27.1 ; \mathrm{CH}_{2} \delta 110.8$, 108.9, 95.2, 72.1, 70.1, 69.6, 66.1, 61.9, 60.6, 42.6, 42.4, 41.3, 39.8, 37.9, 37.5, 33.9, 31.1, 27.1, 19.4; CH $\delta 140.8,135.8,129.8,129.5,128.7,128.1,127.9,114.0,76.6,75.6,75.1$, 74.6, 72.8; C $\delta 170.3,169.0,159.3,144.7,142.0,137.6,134.0,131.1,126.3,81.6,70.1$, 19.4; IR (neat) 3496, 3070, 2939, 2888, 2857, 1760, 1671, 1654, 1612, 1514, 1472, 1428, $1363,1248,1173,1111,1048,895,823,739,703 \mathrm{~cm}^{-1}$; HRMS (ESI) calcd 1025.4847 for $\mathrm{C}_{59} \mathrm{H}_{74} \mathrm{O}_{12} \mathrm{NaSi}(\mathrm{M}+\mathrm{Na})$, found 1025.4835 .

Ethoxyethyl acetal (20).-A solution of alcohol 19 (38.2 mg, $0.038 \mathrm{mmol}, 1.0$ equiv) in a 4:1 mixture of $\mathrm{CH}_{2} \mathrm{Cl}_{2} /$ ethyl vinyl ether $(3.80 \mathrm{~mL}, 0.01 \mathrm{M})$ was prepared in a $10 \mathrm{~mL}$ flask under $\mathrm{N}_{2}$. After being cooled to $0{ }^{\circ} \mathrm{C}$, PPTS $(1.0 \mathrm{mg}, 0.004 \mathrm{mmol}, 0.1$ equiv) was added, and the mixture was then stirred at $0{ }^{\circ} \mathrm{C}$ for $1 \mathrm{~h}$. The reaction mixture was warmed to $\mathrm{rt}$ and stirred for $1 \mathrm{~h}$. The reaction mixture was quenched with brine $(10 \mathrm{~mL})$, extracted with EtOAc $(3 \times 10 \mathrm{~mL})$, dried over $\mathrm{Na}_{2} \mathrm{SO}_{4}$, filtered, and concentrated. The product was purified using a $1 \times 10 \mathrm{~cm}$ silica gel column, eluting with a gradient of $100 \mathrm{~mL}$ of $15 \%$ EtOAc, followed by $100 \mathrm{~mL}$ of $25 \%$ EtOAc/hexanes, collecting $5 \mathrm{~mL}$ fractions. Fractions $18-30$ were concentrated to yield the product (32 mg, 78\%) as a colorless oil: $R_{f}=0.77$ (50\% EtOAc/hexanes); $[a]_{\mathrm{D}}{ }^{20}=+6.5\left(c=1.6, \mathrm{CHCl}_{3}\right) ;{ }^{1} \mathrm{H} \mathrm{NMR}\left(500 \mathrm{MHz}, \mathrm{CDCl}_{3}\right) 7.70-7.67$ $(\mathrm{m}, 4 \mathrm{H}), 7.45-7.28(\mathrm{~m}, 11 \mathrm{H}), 7.18(\mathrm{~d}, J=8.5 \mathrm{~Hz}, 2 \mathrm{H}) 6.86(\mathrm{~d}, J=8.5 \mathrm{~Hz}, 2 \mathrm{H}), 6.34(\mathrm{t}, J=$ $7.0 \mathrm{~Hz}, 1 \mathrm{H}), 4.76(\mathrm{~s}, 2 \mathrm{H}), 4.75-4.68(\mathrm{~m}, 4 \mathrm{H}), 4.61(\mathrm{~s}, 1 \mathrm{H}), 4.59(\mathrm{~s}, 2 \mathrm{H}), 4.40$ (ABq, $J=10.5$ $\mathrm{Hz}, \Delta v=43.8 \mathrm{~Hz}, 2 \mathrm{H}), 4.28(\mathrm{ABq}, J=12.5 \mathrm{~Hz}, \Delta v=64.5 \mathrm{~Hz}, 2 \mathrm{H}), 3.94-3.88(\mathrm{~m}, 2 \mathrm{H})$, 3.84-3.81 (m, 1H), 3.80 (s, 3H), 3.77-3.72 (m, 1H), 3.70-3.64 (m, 4H), 3.63-3.51 (m, 3H), 3.50-3.44 (m, 2H), 3.09-3.02 (m, 1H), 2.98-2.91 (m, 1H), $2.85(\mathrm{~d}, J=16.5 \mathrm{~Hz}, 1 \mathrm{H}), 2.75$ (d, $J=16.5 \mathrm{~Hz}, 1 \mathrm{H}), 2.43$ (d, $J=13 \mathrm{~Hz}, 1 \mathrm{H}), 2.30-2.15$ (m, 4H), 2.06 (ddd, $J=14,8.5,6.5$ $\mathrm{Hz}, 1 \mathrm{H}), 2.02-1.94(\mathrm{~m}, 2 \mathrm{H}), 1.91(\mathrm{t}, J=12.5 \mathrm{~Hz}, 1 \mathrm{H}), 1.80$ (ddddd, $J=13,13,13,6.5,6.5$ $\mathrm{Hz}, 2 \mathrm{H}), 1.73-1.63(\mathrm{~m}, 3 \mathrm{H}), 1.31(\mathrm{~d}, J=5.0 \mathrm{~Hz}, 3 \mathrm{H}), 1.21(\mathrm{t}, J=6.5 \mathrm{~Hz}, 3 \mathrm{H}), 1.06(\mathrm{~s}, 9 \mathrm{H})$; ${ }^{13} \mathrm{C}$ NMR $\left(125 \mathrm{MHz}, \mathrm{CDCl}_{3}\right) \delta 170.3,168.5,159.3,144.8,142.0,141.7,137.6,135.8$, 134.04, 134.01, 131.1, 129.8, 129.5, 128.7, 128.1, 127.86, 127.84, 125.3, 114.0, 110.8, $108.8,99.9,99.8,95.2,81.3,76.6,75.6,75.0,74.6,72.8,72.0,70.1,69.5,66.0,64.02$, 63.99, 61.3, 60.6, 55.5, 42.6, 42.5, 41.3, 41.0, 39.9, 37.9, 37.6, 33.7, 28.6, 27.2, 20.1, 19.4, 15.5; DEPT (125 MHz, $\left.\mathrm{CDCl}_{3}\right) \mathrm{CH}_{3} \delta 55.5,27.1,20.1,15.5 ; \mathrm{CH}_{2} \delta 110.8,108.9,95.1$, 72.1, 70.1, 69.5, 66.0, 64.0, 61.3, 60.6, 42.6, 42.5, 41.4, 41.0, 39.9, 37.9, 37.6, 33.7, 28.6; CH $\delta 141.7,135.8,129.8,129.5,128.7,128.1,127.9,114.0,99.8,76.6,75.6,75.0,74.6$, 72.8; C $\delta 170.3,168.5,159.3,144.8,142.0,137.6,134.1,131.1,125.3,81.3,19.4$; IR (neat) $2939,2887,1761,1656,1612,1513,1428,1378,1248,1172,1110,1049,894,823,738$, $703 \mathrm{~cm}^{-1}$. 
C1 Alcohol (21)._A solution of $\mathbf{2 0}$ ( $90.3 \mathrm{mg}, 0.084 \mathrm{mmol}, 1.0$ equiv) was prepared in DMF $(1.70 \mathrm{~mL}, 0.05 \mathrm{M})$ in a $5 \mathrm{~mL}$ flask. A solution of AcOH in DMF (1.0 M, $84 \mu \mathrm{L}, 1.0$ equiv) and TBAF in THF (1.0 M, $84 \mu \mathrm{L}, 1.0$ equiv) were mixed together and added to the reaction mixture. The mixture was stirred at rt overnight, quenched by the addition of a solution of saturated aqueous $\mathrm{NaHCO}_{3}(5.0 \mathrm{~mL})$, and diluted with brine $(10 \mathrm{~mL})$. After extraction with EtOAc $(3 \times 10 \mathrm{~mL})$, the solution was dried over $\mathrm{Na}_{2} \mathrm{SO}_{4}$, filtered, and concentrated. The crude product was then purified using a $1 \times 10 \mathrm{~cm}$ silica gel column, eluting with a gradient of 25-60\% EtOAc/hexanes, collecting $5 \mathrm{~mL}$ fractions. Fractions 50 90 were concentrated to yield the product $(70.1 \mathrm{mg}, 100 \%)$ as a colorless oil: $R_{f}=0.15$ (50\% EtOAc/hexanes); $[a]_{\mathrm{D}}{ }^{20}=+9.5\left(c=1.1, \mathrm{CHCl}_{3}\right) ;{ }^{1} \mathrm{H} \mathrm{NMR}\left(500 \mathrm{MHz}, \mathrm{CDCl}_{3}\right) 7.36-$ $7.29(\mathrm{~m}, 5 \mathrm{H}), 7.26(\mathrm{~d}, J=8.0 \mathrm{~Hz}, 2 \mathrm{H}), 6.89(\mathrm{~d}, J=8.5 \mathrm{~Hz}, 2 \mathrm{H}), 6.34(\mathrm{t}, J=7.0 \mathrm{~Hz}, 1 \mathrm{H})$, $4.77(\mathrm{~s}, 2 \mathrm{H}), 4.77$ (s, 1H), $4.72(\mathrm{~s}, 2 \mathrm{H}), 4.70(\mathrm{q}, J=5.5 \mathrm{~Hz}, 1 \mathrm{H}), 4.67(\mathrm{~s}, 1 \mathrm{H}), 4.59$ (s, 2H), $4.47(\mathrm{ABq}, J=10.5 \mathrm{~Hz}, \Delta v=26.5 \mathrm{~Hz}, 2 \mathrm{H}), 4.28(\mathrm{ABq}, J=11.5 \mathrm{~Hz}, \Delta v=42.0 \mathrm{~Hz}, 2 \mathrm{H})$, $3.95(\mathrm{dd}, J=12.5,2.5 \mathrm{~Hz}, 1 \mathrm{H}), 3.90-3.85(\mathrm{~m}, 1 \mathrm{H}), 3.83-3.81(\mathrm{~m}, 1 \mathrm{H}), 3.80(\mathrm{~s}, 3 \mathrm{H}), 3.75-$ $3.62(\mathrm{~m}, 6 \mathrm{H}), 3.56-3.53(\mathrm{~m}, 2 \mathrm{H}), 3.50-3.44(\mathrm{~m}, 3 \mathrm{H}), 3.08-3.02(\mathrm{~m}, 1 \mathrm{H}), 3.00-2.94(\mathrm{~m}$, $1 \mathrm{H},), 2.89-2.71(\mathrm{~m}, 2 \mathrm{H}), 2.45$ (d, $J=13 \mathrm{~Hz}, 1 \mathrm{H}), 2.25$ (m, 2H), 2.18 (d, $J=13.5 \mathrm{~Hz}, 2 \mathrm{H})$, 2.07-2.01 (m, 1H), 1.99-1.94 (m, 3H), 1.92-1.89 (m, 1H), 1.80-1.70 (m, 2H), 1.68-1.63 $(\mathrm{m}, 2 \mathrm{H}), 1.31(\mathrm{~d}, J=5.5 \mathrm{~Hz}, 3 \mathrm{H}), 1.21(\mathrm{t}, J=6.5 \mathrm{~Hz}, 3 \mathrm{H}) ;{ }^{13} \mathrm{C} \mathrm{NMR}\left(125 \mathrm{MHz}, \mathrm{CDCl}_{3}\right) \delta$ 170.3, 168.5, 159.6, 144.4, 142.1, 141.7, 137.6, 130.6, 129.7, 128.7, 128.1, 125.3, 114.2, $110.8,109.1,99.86,99.84,95.2,81.3,76.7,75.8,75.4,75.3,74.8,72.0,70.1,69.5,66.1$, 64.0, 61.3, 60.4, 55.5, 42.5, 41.7, 41.4, 40.9, 39.9, 37.6, 36.8, 33.8, 31.2, 28.6, 20.1, 15.5; DEPT (125 MHz, $\left.\mathrm{CDCl}_{3}\right) \mathrm{CH}_{3} \delta 55.5,20.1,15.5 ; \mathrm{CH}_{2} \delta 110.8,109.1,95.2,72.0,70.1$, 69.5, 66.1, 64.0, 61.3, 60.4, 42.5, 41.7, 41.4, 40.9, 39.9, 37.6, 36.8, 33.8, 31.2, 28.6; CH $\delta$ $141.7,129.7,128.7,128.1,114.2,99.9,76.7,75.8,75.4,75.3,74.8$; C $\delta 170.3,168.5,159.6$, 144.4, 142.1, 137.6, 130.6, 125.3, 81.3; IR (neat) 3478, 2940, 2886, 1760, 1653, 1612, 1514, 1441, 1378, 1249, 1173, 1108, 1048, 898, 822, 747, $700 \mathrm{~cm}^{-1}$; HRMS (ESI) calcd 859.4245 for $\mathrm{C}_{47} \mathrm{H}_{64} \mathrm{O}_{13} \mathrm{Na}(\mathrm{M}+\mathrm{Na})$, found 859.4240 .

C1 Carboxylic Acid (22).-To a stirring solution of 21 (17.1 mg, $0.02 \mathrm{mmol}, 1.0$ equiv) in $\mathrm{CH}_{2} \mathrm{Cl}_{2}(200 \mu \mathrm{L}, 0.1 \mathrm{M})$ in a $5 \mathrm{~mL}$ vial was added $i$ - $\operatorname{Pr}_{2} \mathrm{NEt}(20 \mu \mathrm{L}, 0.13 \mathrm{mmol}, 7.0$ equiv), followed by DMSO (10 $\mu \mathrm{L}, 0.19 \mathrm{mmol}, 10.0$ equiv). The solution was chilled to $0{ }^{\circ} \mathrm{C}$, and $\mathrm{SO}_{3} \cdot \operatorname{Pyr}(12 \mathrm{mg}, 0.08 \mathrm{mmol}, 4.0$ equiv) was added in one portion. After being stirred for $1.5 \mathrm{~h}$ at $0{ }^{\circ} \mathrm{C}$, the reaction mixture was quenched with saturated aqueous $\mathrm{NaHCO}_{3}$ solution $(2.0 \mathrm{~mL})$. After extraction with EtOAc $(3 \times 5 \mathrm{~mL})$, the solution was dried over $\mathrm{Na}_{2} \mathrm{SO}_{4}$, filtered, and concentrated. The crude aldehyde was purified on a plug of silica gel in a Pasteur pipet, eluting with $25 \%$ EtOAc/hexanes. The crude aldehyde was used as is without characterization.

The aldehyde ( $0.02 \mathrm{mmol}, 1.0$ equiv) was taken up in $t \mathrm{BuOH}(270 \mu \mathrm{L})$ in a $5 \mathrm{~mL}$ vial. To a stirring solution of aldehyde, 2-methyl-2-butene $(270 \mu \mathrm{L})$ was added, followed by aqueous $\mathrm{KH}_{2} \mathrm{PO}_{4}$ solution $(1.25 \mathrm{M}, 90 \mu \mathrm{L}, 0.11 \mathrm{mmol}, 6.0$ equiv). The rapidly stirred mixture was chilled to $-10{ }^{\circ} \mathrm{C}$ in a $\mathrm{MeOH} / \mathrm{ice}$ bath. To the cold solution was added $80 \% \mathrm{NaClO}_{2}(11 \mathrm{mg}$, $0.1 \mathrm{mmol}, 5.0$ equiv) in one portion. After being stirred for $1 \mathrm{~h}$ at $-10{ }^{\circ} \mathrm{C}$, the reaction was quenched with aqueous $\mathrm{pH} 4.0$ acetate buffer $(0.1 \mathrm{M}, 5.0 \mathrm{~mL})$. After being extracted with EtOAc $(4 \times 5.0 \mathrm{~mL})$, the solution was dried over $\mathrm{Na}_{2} \mathrm{SO}_{4}$, filtered, and concentrated. The 
product was purified using a $0.5 \times 5 \mathrm{~cm}$ Pasteur pipet silica gel column, eluting with $80 / 20 / 1$ toluene/EtOAc/AcOH, collecting $1.0 \mathrm{~mL}$ fractions. Fractions $4-14$ were concentrated to yield the product (14 mg, $82 \%$ ) as a colorless oil: $R_{f}=0.37$ (80/20/1 $\left.\mathrm{PhCH}_{3} / \mathrm{EtOAc} / \mathrm{AcOH}\right)$; $[a]_{\mathrm{D}}{ }^{20}=+14\left(c=0.45, \mathrm{CHCl}_{3}\right) ;{ }^{1} \mathrm{H} \mathrm{NMR}\left(500 \mathrm{MHz}, \mathrm{CDCl}_{3}\right) 7.38-7.28(\mathrm{~m}, 5 \mathrm{H}), 7.25(\mathrm{~d}, J$ $=8.5 \mathrm{~Hz}, 2 \mathrm{H}), 6.88(\mathrm{~d}, J=9.0 \mathrm{~Hz}, 2 \mathrm{H}), 6.34(\mathrm{ddd}, J=5.0,5.0,2.0 \mathrm{~Hz}, 1 \mathrm{H}), 4.77(\mathrm{~s}, 2 \mathrm{H})$, 4.76-4.69 (m, 5H), $4.60(\mathrm{~s}, 2 \mathrm{H}), 4.49(\mathrm{ABq}, J=11 \mathrm{~Hz}, \Delta v=60 \mathrm{~Hz}, 2 \mathrm{H}), 4.32(\mathrm{dd}, J=13$, $4.5 \mathrm{~Hz}, 1 \mathrm{H}), 4.28(\mathrm{dd}, J=15,3.5 \mathrm{~Hz}, 1 \mathrm{H}), 4.09-4.07(\mathrm{~m}, 1 \mathrm{H}), 3.94(\mathrm{dd}, J=11.5,2.0 \mathrm{~Hz}$, $1 \mathrm{H}), 3.80(\mathrm{~s}, 3 \mathrm{H}), 3.72-3.62(\mathrm{~m}, 4 \mathrm{H}), 3.58-3.54(\mathrm{~m}, 4 \mathrm{H}), 3.43-3.37(\mathrm{~m}, 1 \mathrm{H}), 3.10-2.92(\mathrm{~m}$, 2H), $2.81(\mathrm{ABq}, J=16.5 \mathrm{~Hz}, \Delta v=40.8 \mathrm{~Hz}, 2 \mathrm{H}), 2.63(\mathrm{~m}, 2 \mathrm{H}), 2.45(\mathrm{~d}, J=12.5 \mathrm{~Hz}, 1 \mathrm{H})$, 2.27-2.19 (m, 3H), 2.15 (d, $J=12.5 \mathrm{~Hz}, 1 \mathrm{H}), 2.08-2.02(\mathrm{~m}, 1 \mathrm{H}), 1.96(\mathrm{~m}, 3 \mathrm{H}), 1.79$ (dd, $J=$ $14,8.0 \mathrm{~Hz}, 1 \mathrm{H}), 1.70(\mathrm{ddd}, J=10,5.0,5.0 \mathrm{~Hz}, 1 \mathrm{H}), 1.65(\mathrm{ddd}, J=11,5.5,5.0 \mathrm{~Hz}, 1 \mathrm{H}), 1.32$ $(\mathrm{t}, J=5.5 \mathrm{~Hz}, 3 \mathrm{H}), 1.21(\mathrm{t}, J=7.0 \mathrm{~Hz}, 3 \mathrm{H}) ;{ }^{13} \mathrm{C} \mathrm{NMR}\left(125 \mathrm{MHz}, \mathrm{CDCl}_{3}\right) \delta 173.8,170.8$, 168.6, 159.5, 144.3, 141.8, 141.3, 137.6, 130.4, 129.6, 128.7, 128.1, 125.5, 114.1, 111.0, 109.1, 99.8, 95.2, 81.4, 76.6, 75.9, 75.1, 75.0, 73.3, 72.0, 70.1, 69.6, 66.5, 64.0, 61.3, 55.5, 42.7, 42.0, 41.2, 41.0, 40.1, 40.0, 37.5, 33.9, 28.5, 20.0, 15.5; DEPT (125 MHz, $\left.\mathrm{CDCl}_{3}\right)$ $\mathrm{CH}_{3} \delta 55.5,20.0,15.5 ; \mathrm{CH}_{2} \delta 111.0,109.1,95.2,72.0,70.1,69.6,66.5,64.0,61.3,42.7$, $42.0,41.2,40.1,40.0,37.5,33.9,28.5$; CH $\delta 141.3,129.6,128.7,128.1,114.1,99.8,76.6$, 75.9, 75.1, 75.0, 73.3, 41.0; C $\delta 173.8,170.8,168.6,159.5,144.3,141.8,137.6,130.4$, 125.5, 81.4; IR (neat) 2938, 1761, 1684, 1653, 1514, 1379, 1249, 1173, 1108, 1047, 899, 823, 740, $699 \mathrm{~cm}^{-1}$; HRMS (ESI) calcd 873.4037 for $\mathrm{C}_{47} \mathrm{H}_{62} \mathrm{O}_{14} \mathrm{Na}(\mathrm{M}+\mathrm{Na})$, found 873.4047.

seco-Acid (23).-To a stirring solution of carboxylic acid 22 (46 mg, $0.05 \mathrm{mmol}, 1.0$ equiv) in $\mathrm{MeOH}(5.4 \mathrm{~mL}, 0.01 \mathrm{M})$ in a $10 \mathrm{~mL}$ flask under $\mathrm{N}_{2}$ was added PPTS (6.4 mg, 0.03 mmol, 0.47 equiv). After being stirred overnight, the reaction mixture was diluted with brine $(25 \mathrm{~mL})$ and extracted with EtOAc $(3 \times 10 \mathrm{~mL})$. After being dried over $\mathrm{Na}_{2} \mathrm{SO}_{4}$, the solution was filtered and concentrated. The crude product was purified using a $1 \times 10 \mathrm{~cm}$ silica gel column, eluting with $50 \mathrm{~mL}$ of 50\% EtOAc/hexanes and then with 50/40/10 hexanes/EtOAc/ $\mathrm{MeOH}$, collecting $5 \mathrm{~mL}$ fractions. Fractions 12-42 were concentrated to yield the seco-acid $(39.2 \mathrm{mg}, 93 \%)$ as a colorless oil: $R_{f}=0.21(50 / 40 / 10 \mathrm{Hexanes} / \mathrm{EtOAc} / \mathrm{MeOH}) ;[a]_{\mathrm{D}}{ }^{20}=$ $+12.1(c=0.860, \mathrm{MeOH}) ;{ }^{1} \mathrm{H}$ NMR $\left(500 \mathrm{MHz}, \mathrm{CDCl}_{3}\right) 7.38-7.29(\mathrm{~m}, 5 \mathrm{H}), 7.25(\mathrm{~d}, J=8.0$ $\mathrm{Hz}, 2 \mathrm{H}), 6.88(\mathrm{~d}, J=9.0 \mathrm{~Hz}, 2 \mathrm{H}), 6.34(\mathrm{t}, J=7.5 \mathrm{~Hz}, 1 \mathrm{H}), 4.78(\mathrm{~m}, 3 \mathrm{H}), 4.75-4.72(\mathrm{~m}, 2 \mathrm{H})$, $4.68(\mathrm{~s}, 1 \mathrm{H}), 4.61(\mathrm{~s}, 2 \mathrm{H}), 4.49(\mathrm{ABq}, J=10.5 \mathrm{~Hz}, \Delta v=52.2 \mathrm{~Hz}, 2 \mathrm{H}), 4.32(\mathrm{ABq}, J=12$ $\mathrm{Hz}, \Delta v=27.9 \mathrm{~Hz}, 2 \mathrm{H}), 4.11-4.08(\mathrm{~m}, 1 \mathrm{H}), 3.95(\mathrm{dd}, J=12,2.5 \mathrm{~Hz}, 1 \mathrm{H}), 3.80(\mathrm{~s}, 3 \mathrm{H}), 3.82-$ $3.74(\mathrm{~m}, 2 \mathrm{H}), 3.68$ (dd, $J=11,1.0 \mathrm{~Hz}, 2 \mathrm{H}), 3.58-3.52(\mathrm{~m}, 1 \mathrm{H}), 3.47$ (t, $J=10.5 \mathrm{~Hz}, 1 \mathrm{H})$, $3.42-3.35(\mathrm{~m}, 1 \mathrm{H}), 3.10$ (dddd, $J=13.5,7.0,7.0,7.0 \mathrm{~Hz}, 1 \mathrm{H}), 3.00-2.98(\mathrm{~m}, 3 \mathrm{H}), 2.63(\mathrm{~d}, J$ $=6.0 \mathrm{~Hz}, 2 \mathrm{H}), 2.45(\mathrm{~d}, J=13 \mathrm{~Hz}, 1 \mathrm{H}), 2.29-2.20(\mathrm{~m}, 3 \mathrm{H}), 2.16(\mathrm{~d}, J=13 \mathrm{~Hz}, 1 \mathrm{H}), 2.08-$ $2.02(\mathrm{~m}, 2 \mathrm{H}), 2.02-1.90(\mathrm{~m} 3 \mathrm{H}), 1.79(\mathrm{dd}, J=13,8.0 \mathrm{~Hz}, 1 \mathrm{H}), 1.72-1.62(\mathrm{~m}, 2 \mathrm{H}) ;{ }^{13} \mathrm{C}$ NMR $\left(125 \mathrm{MHz}, \mathrm{CDCl}_{3}\right) \delta 170.7,169.3,159.5,144.2,141.9,140.4,137.6,130.4,129.6$, 129.3, 128.7, 128.4, 128.1, 125.5, 114.1, 111.0, 109.2, 95.2, 81.8, 76.7, 75.9, 75.3, 74.9, 73.6, 72.1, 70.2, 69.8, 66.7, 61.9, 55.5, 42.8, 42.0, 41.2, 41.1, 40.3, 39.9, 37.6, 34.0, 30.9; DEPT $\left(125 \mathrm{MHz}, \mathrm{CDCl}_{3}\right) \mathrm{CH}_{3} \delta 55.5 ; \mathrm{CH}_{2} \delta 111.0,109.2,95.2,72.1,70.2,69.8,66.7$, $61.9,42.8,42.0,41.2,41.1,40.3,39.9,37.6,34.0,30.9$; CH $\delta 140.4,129.6,128.7,128.4$, 128.1, 114.1, 76.7, 75.9, 75.3, 74.9, 73.6; C $\delta 170.7,169.3,159.5,144.2,141.9,137.6$, 130.4, 129.3, 125.5, 81.8; IR (neat) 3467, 3072, 3032, 2936, 2891, 1757, 1673, 1654, 1613, 
1586, 1514, 1498, 1455, 1439, 1421, 1399, 1374, 1302, 1249, 1174, 1108, 1081, 1045, 898, $848,822 \mathrm{~cm}^{-1}$; HRMS (ESI) calcd 801.3462 for $\mathrm{C}_{43} \mathrm{H}_{54} \mathrm{O}_{13} \mathrm{Na}(\mathrm{M}+\mathrm{Na})$, found 801.3462 .

Macrolactone (24).-To a $100 \mathrm{~mL}$ flask under $\mathrm{N}_{2}$ was added toluene $(14.5 \mathrm{~mL})$, followed by 2,4,6-trichlorobenzoyl chloride ( $230 \mu \mathrm{L}$ of $0.1 \mathrm{M}, 0.023 \mathrm{mmol}, 1.0$ equiv), $\mathrm{Et}_{3} \mathrm{~N}$ ( $460 \mu \mathrm{L}$ of $0.1 \mathrm{M}, 0.046 \mathrm{mmol}, 2.0$ equiv), and DMAP ( $23 \mu \mathrm{L}$ of $0.1 \mathrm{M}, 0.002 \mathrm{mmol}, 0.1$ equiv). All of these solutions were prepared in toluene. A solution of seco-acid $\mathbf{2 3}(17.8 \mathrm{mg}, 0.02 \mathrm{mmol}$, 1.0 equiv) in toluene $(14.5 \mathrm{~mL}$ ) was added via syringe pump at $0.75 \mathrm{~mL} / \mathrm{h}$ to the stirring solution at $40{ }^{\circ} \mathrm{C}$. The addition was complete after $20 \mathrm{~h}$. The transfer was completed by washing the syringe with toluene $(1.0 \mathrm{~mL})$ and adding this to the reaction mixture via syringe pump at $0.75 \mathrm{~mL} / \mathrm{h}$. After being stirred at $40{ }^{\circ} \mathrm{C}$ for $3 \mathrm{~h}$, the reaction mixture was cooled to $\mathrm{rt}$ and quenched with aqueous $\mathrm{NaHCO}_{3}$ solution $(50 \mathrm{~mL})$. The mixture was extracted with EtOAc $(3 \times 10 \mathrm{~mL})$. The combined organic phase was washed with brine (50 $\mathrm{mL}$ ), dried over $\mathrm{Na}_{2} \mathrm{SO}_{4}$, filtered, and concentrated. The product was purified using a $1 \times 10$ $\mathrm{cm}$ silica gel column, eluting with $25 \%$ EtOAc/hexanes, collecting $5 \mathrm{~mL}$ fractions. Fractions $17-37$ were concentrated to the yield the product $(9.3 \mathrm{mg}, 54 \%)$ as a colorless oil: $R_{f}=0.56$ $\left(50 \%\right.$ EtOAc/hexanes); $[a]_{\mathrm{D}}{ }^{20}=+27\left(c=0.69, \mathrm{CHCl}_{3}\right) ;{ }^{1} \mathrm{H} \mathrm{NMR}\left(500 \mathrm{MHz}, \mathrm{CDCl}_{3}\right) 7.39$ $7.31(\mathrm{~m}, 5 \mathrm{H}), 7.22(\mathrm{~d}, J=9.0 \mathrm{~Hz}, 2 \mathrm{H}), 6.88(\mathrm{~d}, J=8.5 \mathrm{~Hz}, 2 \mathrm{H}), 6.28(\mathrm{t}, J=7.0 \mathrm{~Hz}, 1 \mathrm{H})$, $4.81(\mathrm{~s}, 1 \mathrm{H}), 4.80(\mathrm{~s}, 2 \mathrm{H}), 4.75(\mathrm{~s}, 1 \mathrm{H}), 4.69(\mathrm{~s}, 2 \mathrm{H}), 4.62(\mathrm{~s}, 2 \mathrm{H}), 4.41(\mathrm{~s}, 2 \mathrm{H}), 4.27$ (ddd, $J=$ $15,8.0,3.5 \mathrm{~Hz}, 1 \mathrm{H}), 4.16-4.09(\mathrm{~m}, 3 \mathrm{H}), 3.81(\mathrm{~s}, 3 \mathrm{H}), 3.74(\mathrm{dd}, J=12,2.5 \mathrm{~Hz}, 1 \mathrm{H}), 3.71(\mathrm{~s}$, $2 \mathrm{H}), 3.60(\mathrm{t}, J=11 \mathrm{~Hz}, 1 \mathrm{H}), 3.43(\mathrm{t}, J=11 \mathrm{~Hz}, 1 \mathrm{H}), 3.27(\mathrm{t}, J=11 \mathrm{~Hz}, 1 \mathrm{H}), 3.18-3.10(\mathrm{~m}$, 1H), 2.97-2.88 (m, 1H), 2.83 (dd, $J=17,2.5 \mathrm{~Hz}, 1 \mathrm{H}), 2.76(\mathrm{dd}, J=15.5,2.5 \mathrm{~Hz}, 1 \mathrm{H}), 2.72$ (d, $J=17 \mathrm{~Hz}, 1 \mathrm{H}), 2.56(\mathrm{dd}, J=15.5,10.5 \mathrm{~Hz}, 1 \mathrm{H}), 2.46(\mathrm{~d}, J=13 \mathrm{~Hz}, 1 \mathrm{H}), 2.35$ (d, $J=15$ $\mathrm{Hz}, 1 \mathrm{H}), 2.27$ (t, $J=12.5 \mathrm{~Hz}, 1 \mathrm{H}), 2.20(\mathrm{t}, J=11.5 \mathrm{~Hz}, 2 \mathrm{H}), 2.06-2.00(\mathrm{~m}, 1 \mathrm{H}), 1.97-1.92$ $(\mathrm{m}, 3 \mathrm{H}), 1.80(\mathrm{~m}, 1 \mathrm{H}), 1.75-1.69(\mathrm{~m}, 1 \mathrm{H}), 1.66-1.61(\mathrm{~m}, 2 \mathrm{H}) ;{ }^{13} \mathrm{C} \mathrm{NMR}\left(125 \mathrm{MHz}, \mathrm{CDCl}_{3}\right)$ $\delta 171.5,170.0,168.8,159.5,143.9,141.6,138.1,137.6,130.6,129.5,128.8,128.2,127.3$, 114.1, 111.3, 109.5, 95.3, 82.3, 77.8, 77.5, 76.6, 75.9, 74.8, 74.4, 73.0, 70.3, 69.9, 67.8, 64.0, 55.5, 43.0, 42.2, 41.7, 41.3, 39.6, 37.6, 34.3, 27.2; DEPT (125 MHz, $\left.\mathrm{CDCl}_{3}\right) \mathrm{CH}_{3} \delta$ 55.5; $\mathrm{CH}_{2} \delta 111.3,109.5,95.3,73.0,70.3,69.9,67.8,64.0,43.0,42.2,41.7,41.3,39.6$, $37.6,34.3,27.2$; CH $\delta 138.1,129.5,128.8,128.2,114.1,77.8,76.6,75.9,74.9,74.4$; C $\delta$ 171.5, 170.0, 168.8, 159.5, 143.9, 141.6, 137.6, 130.6, 127.3, 82.3, 77.5; IR (neat) 3073, 2929, 2856, 1819, 1760, 1739, 1692, 1674, 1613, 1581, 1550, 1514, 1454, 1440, 1405, 1369, 1326, 1301, 1249, 1207, 1178, 1083, 1044, 987, $899 \mathrm{~cm}^{-1}$; HRMS (ESI) calcd 783.3356 for $\mathrm{C}_{43} \mathrm{H}_{52} \mathrm{O}_{12} \mathrm{Na}(\mathrm{M}+\mathrm{Na})$, found 783.3356 .

Merle 46.-To a stirring solution of macrolactone $24(6.9 \mathrm{mg}, 0.01 \mathrm{mmol}, 1.0$ equiv) in $\mathrm{CH}_{2} \mathrm{Cl}_{2}(0.90 \mathrm{~mL}, 0.01 \mathrm{M})$ was added DDQ $(21 \mathrm{mg}, 0.1 \mathrm{mmol}, 10.0$ equiv). The reaction mixture was stirred at $0{ }^{\circ} \mathrm{C}$ for $2 \mathrm{~h}$ and then quenched with saturated aqueous $\mathrm{NaHCO}_{3}$ solution $(10 \mathrm{~mL})$. The reaction mixture was extracted with $\mathrm{CH}_{2} \mathrm{Cl}_{2}(3 \times 10 \mathrm{~mL})$, dried over $\mathrm{Na}_{2} \mathrm{SO}_{4}$, filtered, and concentrated. The crude product was used without purification.

To the previously described crude alcohol contained in a $5 \mathrm{~mL}$ vial was added a solution of $\mathrm{LiBF}_{4}$ in $25: 1 \mathrm{MeCN} / \mathrm{H}_{2} \mathrm{O}(0.25 \mathrm{M}, 1.62 \mathrm{~mL}, 0.41 \mathrm{mmol}, 45$ equiv $)$. After being flushed with $\mathrm{N}_{2}$, the vial was capped and heated at $80{ }^{\circ} \mathrm{C}$ overnight with stirring. After being cooled to $\mathrm{rt}$, the solvent was evaporated and the reaction mixture was diluted with brine $(10 \mathrm{~mL})$ 
and extracted with EtOAc $(3 \times 10 \mathrm{~mL})$. After being dried over $\mathrm{Na}_{2} \mathrm{SO}_{4}$, the solution was filtered and concentrated. The product was purified using a $1 \times 5 \mathrm{~cm}$ silica gel column, eluting with $60 \%$ EtOAc/pentane, collecting $1 \mathrm{~mL}$ fractions. Fractions 11-56 were concentrated to yield the product ( $3.4 \mathrm{mg}, 73 \%$ over two steps) as a colorless oil: $R_{f}=0.40$ $(50 / 40 / 10$ hexanes/EtOAc/MeOH $) ;[a]_{\mathrm{D}}{ }^{20}=+6.2\left(c=0.065, \mathrm{CHCl}_{3}\right) ;{ }^{1} \mathrm{H} \mathrm{NMR}(500 \mathrm{MHz}$, $\left.\mathrm{CDCl}_{3}\right) 6.29(\mathrm{t}, J=7.5 \mathrm{~Hz}, 1 \mathrm{H}), 4.83(\mathrm{~d}, J=18 \mathrm{~Hz}, 2 \mathrm{H}), 4.74(\mathrm{~s}, 2 \mathrm{H}), 4.65$ (d, $J=12 \mathrm{~Hz}$, $1 \mathrm{H}), 4.38$ (ddd, $J=15,8.0,3.5 \mathrm{~Hz}, 1 \mathrm{H}), 4.20-4.17(\mathrm{~m}, 1 \mathrm{H}), 4.14$ (d, $J=12 \mathrm{~Hz}, 2 \mathrm{H}), 3.82$ $(\mathrm{dd}, J=12.5,2.5 \mathrm{~Hz}, 1 \mathrm{H}), 3.79-3.76(\mathrm{~m}, 1 \mathrm{H}), 3.70(\mathrm{dd}, J=12,6.5 \mathrm{~Hz}, 1 \mathrm{H}), 3.55-3.49$ (m, $1 \mathrm{H}), 3.46-3.41(\mathrm{~m}, 2 \mathrm{H}), 3.32-3.25(\mathrm{~m}, 2 \mathrm{H}), 2.92$ (dd, $J=16.5,3.0 \mathrm{~Hz}, 1 \mathrm{H}), 2.85-2.79$ (m, 1H), $2.71(\mathrm{dd}, J=15.5,1.5 \mathrm{~Hz}, 1 \mathrm{H}), 2.46$ (d, $J=13 \mathrm{~Hz}, 1 \mathrm{H}), 2.41(\mathrm{dd}, J=16,10.5 \mathrm{~Hz}, 1 \mathrm{H})$, $2.30(\mathrm{~d}, J=14.5 \mathrm{~Hz}, 1 \mathrm{H}), 2.24(\mathrm{~d}, J=12.5 \mathrm{~Hz}, 1 \mathrm{H}), 2.18(\mathrm{~d}, J=13.5 \mathrm{~Hz}, 2 \mathrm{H}), 2.05-1.92(\mathrm{~m}$, 5H), 1.79-1.66 (m, 4H); $\left.{ }^{13} \mathrm{C} \mathrm{NMR} \mathrm{(125} \mathrm{MHz,} \mathrm{CDCl}_{3}\right) \delta 173.6,173.3,170.2,143.8,141.8$, 138.7, 127.7, 111.0, 109.5, 83.8, 76.8, 76.8, 75.2, 67.8, 67.2, 65.1, 64.2, 42.6, 42.4, 41.2, 41.2, 39.7, 37.6, 33.2, 29.9, 27.4; DEPT (125 MHz, $\left.\mathrm{CDCl}_{3}\right) \mathrm{CH}_{3} \delta \mathrm{CH}_{2} \delta 111.0,109.5$, $67.2,65.1,64.2,42.6,42.4,41.2,41.2,39.7,37.6,33.2,29.9,27.4$; $\mathrm{CH} \delta 138.7,76.8,75.2$, 67.8; C $\delta 173.6,173.3,170.2,143.8,141.8,127.7,83.8$; IR (neat) 3488, 2924, 1755, 1652, 1408, 1368, 1327, 1262, 1179, 1104, 907, $733 \mathrm{~cm}^{-1}$; HRMS (ESI) calcd 543.2206 for $\mathrm{C}_{27} \mathrm{H}_{36} \mathrm{O}_{10} \mathrm{Na}(\mathrm{M}+\mathrm{Na})$, found 543.2216.

Pyran Ester (25).-To a stirring solution of carboxylic acid 1 (117 mg, $0.167 \mathrm{mmol}, 1.0$ equiv) in $\mathrm{PhCH}_{3}(1.67 \mathrm{~mL}, 0.1 \mathrm{M})$ in a $10 \mathrm{~mL}$ flask under $\mathrm{N}_{2}$ was added $\mathrm{Et}_{3} \mathrm{~N}$ (93 $\mu \mathrm{L}, 0.67$ mmol, 4.0 equiv). After being stirred for $5 \mathrm{~min}, 2,4,6$-trichlorobenzoyl chloride ( $40 \mu \mathrm{L}, 0.23$ mmol, 1.4 equiv) was added. The reaction mixture was stirred for $1 \mathrm{~h}$. A solution of alcohol 16 (165 mg, $0.29 \mathrm{mmol}, 1.8$ equiv) and DMAP (36 mg, $0.29 \mathrm{mmol}, 1.8$ equiv) in $\mathrm{PhCH}_{3}$ $(500 \mu \mathrm{L})$ was added. $\mathrm{PhCH}_{3}(2 \times 250 \mu \mathrm{L})$ was used to complete the transfer. The reaction mixture was stirred for $1 \mathrm{~h}$ and then quenched with saturated aqueous $\mathrm{NaHCO}_{3}$ solution (25 $\mathrm{mL})$. The mixture was extracted with EtOAc $(3 \times 10 \mathrm{~mL})$, washed with brine $(15 \mathrm{~mL})$, dried over $\mathrm{Na}_{2} \mathrm{SO}_{4}$, filtered, and concentrated. The product was purified using a $2 \times 15 \mathrm{~cm}$ silica gel column, eluting with $15 \%$ EtOAc/hexanes, collecting $5 \mathrm{~mL}$ fractions. Fractions 14-32 were concentrated to yield the product as a colorless oil $(127 \mathrm{mg}, 61 \%): R_{f}=0.48(25 \%$ EtOAc/hexanes); $[a]_{\mathrm{D}}{ }^{20}=+2.48(c=1.62) ;{ }^{1} \mathrm{H} \mathrm{NMR}\left(500 \mathrm{MHz}, \mathrm{CDCl}_{3}\right) \delta 7.70-7.67(\mathrm{~m}$, $4 \mathrm{H}), 7.45-7.37(\mathrm{~m}, 12 \mathrm{H}), 7.35-7.23(\mathrm{~m}, 14 \mathrm{H}), 7.19(\mathrm{~d}, J=8.5 \mathrm{~Hz}, 2 \mathrm{H}), 6.86(\mathrm{~d}, J=8.5 \mathrm{~Hz}$, $2 \mathrm{H}), 6.13(\mathrm{t}, J=7.0 \mathrm{~Hz}, 1 \mathrm{H}), 4.73(\mathrm{~m}, 3 \mathrm{H}), 4.71(\mathrm{~s}, 2 \mathrm{H}), 4.61(\mathrm{~s}, 1 \mathrm{H}), 4.52(\mathrm{~s}, 2 \mathrm{H}), 4.41$ $(\mathrm{ABq}, J=10.5 \mathrm{~Hz}, \Delta v=41.2 \mathrm{~Hz}, 2 \mathrm{H}), 4.25$ (ddddd, $J=13.5,10.5,10.5,6.5,6.5 \mathrm{~Hz}, 2 \mathrm{H}$ ), 3.94-3.91 (m, 2H), 3.85-3.81 (m, 1H), $3.80(\mathrm{~s}, 3 \mathrm{H}), 3.77-3.73(\mathrm{~m}, 1 \mathrm{H}), 3.68$ (ABq, $J=10.5$ $\mathrm{Hz}, \Delta v=22.9 \mathrm{~Hz}, 2 \mathrm{H}), 3.63-3.60(\mathrm{~m}, 1 \mathrm{H}), 3.58-3.51(\mathrm{~m}, 1 \mathrm{H}), 3.50-3.45(\mathrm{~m}, 1 \mathrm{H}), 3.32(\mathrm{~d}, J$ $=10 \mathrm{~Hz}, 1 \mathrm{H}), 3.17(\mathrm{~d}, J=9.5 \mathrm{~Hz}, 1 \mathrm{H}), 3.20-3.14(\mathrm{~m}, 1 \mathrm{H}), 3.13-3.09(\mathrm{~m}, 1 \mathrm{H}), 2.79(\mathrm{~d}, J=$ $16.5 \mathrm{~Hz}, 1 \mathrm{H}), 2.71(\mathrm{~d}, J=16.5 \mathrm{~Hz}, 1 \mathrm{H}), 2.48(\mathrm{~d}, J=12.5 \mathrm{~Hz}, 1 \mathrm{H}), 2.31(\mathrm{~d}, J=13 \mathrm{~Hz}, 1 \mathrm{H})$, $2.27-2.23(\mathrm{~m}, 2 \mathrm{H}), 2.17(\mathrm{~d}, J=13.5 \mathrm{~Hz}, 1 \mathrm{H}), 2.10(\mathrm{ddd}, J=14.0,8.0,5.5 \mathrm{~Hz}, 1 \mathrm{H}), 2.01(\mathrm{t}, J$ $=12 \mathrm{~Hz}, 2 \mathrm{H}), 1.93(\mathrm{t}, J=12 \mathrm{~Hz}, 1 \mathrm{H}), 1.84-1.74(\mathrm{~m}, 2 \mathrm{H}), 1.72-1.62(\mathrm{~m}, 3 \mathrm{H}), 1.07$ (s, 9H); ${ }^{13} \mathrm{C}$ NMR $\left(125 \mathrm{MHz}, \mathrm{CDCl}_{3}\right) \delta 170.9,169.1,159.3,144.8,143.5,142.3,137.7,137.4$, $135.8,134.03,133.99131 .1,129.8,129.5,128.8,128.6,128.1,127.99,127.96,127.87$, $127.85,127.4,114.0,110.6,108.8,95.0,87.2,83.4,77.0,75.7,75.0,74.6,72.8,72.1,70.2$, 69.8, 66.0, 63.9, 60.6, 55.5, 42.6, 42.5, 41.4, 41.1, 39.9, 38.0, 37.7, 34.0, 27.2, 27.2, 19.4; DEPT (125 MHz, $\left.\mathrm{CDCl}_{3}\right) \mathrm{CH}_{3} \delta 55.5,27.2 ; \mathrm{CH}_{2} \delta 110.6,108.8,95.0,72.1,70.2,69.8$, 
66.0, 63.9, 60.6, 42.6, 42.5, 41.4, 41.1, 39.9, 38.0, 37.7, 34.0, 27.2; CH $\delta 137.4,135.8$, $129.8,129.5,128.8,128.6,128.1,128.0,127.9,127.4,114.0,77.0,75.7,75.0,74.6,72.8 ; \mathrm{C}$ $\delta 170.9,169.1,159.3,144.8,143.5,142.3,137.7,134.0,131.1,127.9,87.2,83.4,19.4$; IR (neat) 2936, 1758, 1611, 1513, 1449, 1428, 1362, 1248, 1174, 1110, 1046, 898, 823, 745, 703, $632 \mathrm{~cm}^{-1}$; HRMS (ESI) calcd 1267.5943 for $\mathrm{C}_{78} \mathrm{H}_{88} \mathrm{O}_{12} \mathrm{NaSi}(\mathrm{M}+\mathrm{Na})$, found 1267.5942 .

C1 Alcohol (26).-A solution of ester 25 (25 mg, $0.02 \mathrm{mmol}, 1.0$ equiv) was prepared in THF (200 $\mu \mathrm{L}, 0.1 \mathrm{M}$ ) in a $2 \mathrm{~mL}$ polyethylene vial. To the stirring solution, a $20 \%$

HF.pyridine solution in pyridine $(500 \mu \mathrm{L})(25 \mathrm{~mL} / \mathrm{mmol})$ was added. After being stirred for $2.5 \mathrm{~h}$, the reaction mixture was quenched with brine $(10 \mathrm{~mL})$ and saturated aqueous

$\mathrm{NaHCO}_{3}$ solution $(5 \mathrm{~mL})$. The mixture was extracted with EtOAc $(4 \times 5 \mathrm{~mL})$, dried over $\mathrm{Na}_{2} \mathrm{SO}_{4}$, filtered, and concentrated. The product was purified using a $1 \times 10 \mathrm{~cm}$ silica gel column, eluting with $45 \%$ EtOAc/hexanes, collecting $5 \mathrm{~mL}$ fractions. Fractions 6-22 were concentrated to yield the product as a colorless oil $(16.1 \mathrm{mg}, 80 \%): R_{f}=0.37(50 \% \mathrm{EtOAc} /$ hexanes); $[a]_{\mathrm{D}}{ }^{20}=+2.1(c=0.59) ;{ }^{1} \mathrm{H} \mathrm{NMR}\left(500 \mathrm{MHz}, \mathrm{CDCl}_{3}\right) \delta 7.42-7.40(\mathrm{~m}, 6 \mathrm{H}), 7.35-$ $7.23(\mathrm{~m}, 16 \mathrm{H}), 6.89(\mathrm{~d}, J=9.0 \mathrm{~Hz}, 2 \mathrm{H}), 6.14(\mathrm{t}, J=7.0 \mathrm{~Hz}, 1 \mathrm{H}), 4.77-4.73(\mathrm{~m}, 2 \mathrm{H}), 4.71(\mathrm{~s}$, $2 \mathrm{H}), 4.69(\mathrm{~d}, J=16 \mathrm{~Hz}, 2 \mathrm{H}), 4.52(\mathrm{~s}, 2 \mathrm{H}), 4.47(\mathrm{ABq}, J=10.5 \mathrm{~Hz}, \Delta v=19.5 \mathrm{~Hz}, 2 \mathrm{H})$, $4.30-4.22(\mathrm{~m}, 2 \mathrm{H}), 3.95(\mathrm{dd}, J=11.5,2.5 \mathrm{~Hz}, 1 \mathrm{H}), 3.91-3.86(\mathrm{~m}, 1 \mathrm{H}), 3.84-3.81(\mathrm{~m}, 1 \mathrm{H})$, $3.80(\mathrm{~s}, 3 \mathrm{H}), 3.75-3.71(\mathrm{~m}, 1 \mathrm{H}), 3.68(\mathrm{q}, J=6.0 \mathrm{~Hz}, 2 \mathrm{H}), 3.59-3.55(\mathrm{~m}, 1 \mathrm{H}), 3.51-3.44(\mathrm{~m}$, $2 \mathrm{H}), 3.32(\mathrm{~d}, J=10 \mathrm{~Hz}, 1 \mathrm{H}), 3.22-3.15(\mathrm{~m}, 1 \mathrm{H}), 3.16(\mathrm{~d}, J=10 \mathrm{~Hz}, 1 \mathrm{H}), 3.13-3.08(\mathrm{~m}, 1 \mathrm{H})$, $2.80(\mathrm{dd}, J=16.5,2.0 \mathrm{~Hz}, 1 \mathrm{H}), 2.72(\mathrm{~d}, J=16 \mathrm{~Hz}, 1 \mathrm{H}), 2.51$ (d, $J=13 \mathrm{~Hz}, 1 \mathrm{H}), 2.30-2.23$ $(\mathrm{m}, 3 \mathrm{H}), 2.19$ (d, $J=12.5 \mathrm{~Hz}, 1 \mathrm{H}), 2.10-1.90(\mathrm{~m}, 5 \mathrm{H}), 1.81-1.64(\mathrm{~m}, 5 \mathrm{H}) ;{ }^{13} \mathrm{C}$ NMR $(125$ $\left.\mathrm{MHz}_{\mathrm{CDCl}}\right) \delta 170.9,169.1,159.5,144.4,143.6,142.4,137.7,137.4,130.6,129.7,128.8$, $128.7,128.7,128.1,128.0,128.0,127.4,114.2,110.6,109.1,95.0,87.2,83.4,77.0,75.8$, $75.5,75.4,74.9,72.0,70.2,69.8,66.0,63.9,60.5,55.5,42.5,41.7,41.4,41.0,40.0,37.7$, 36.8, 34.1, 27.2; DEPT (125 MHz, $\left.\mathrm{CDCl}_{3}\right) \mathrm{CH}_{3} \delta 55.5 ; \mathrm{CH}_{2} \delta 110.6,109.1,95.0,72.0$, $70.2,69.8,66.0,63.9,60.5,42.5,41.7,41.4,41.0,40.0,37.7,36.8,34.1,27.2$; CH $\delta 137.4$, $129.7,128.8,128.7,128.1,128.0,127.4,114.2,77.0,75.8,75.5,75.4,74.9$; C $\delta 170.9$, $169.1,159.5,144.4,143.6,142.4,137.7,130.6,128.7,128.0,87.2,83.4$; IR (neat) 3503 , 2936, 2884, 1756, 1684, 1652, 1616, 1516, 1490, 1448, 1362, 1249, 1175, 1078, 1045, 898, $748,704,633 \mathrm{~cm}^{-1}$; HRMS (ESI) calcd 1029.4765 for $\mathrm{C}_{62} \mathrm{H}_{70} \mathrm{O}_{12} \mathrm{Na}(\mathrm{M}+\mathrm{Na})$, found 1029.4774 .

Carboxylic Acid (27).-To a stirring solution of alcohol 26 (25 mg, $0.03 \mathrm{mmol}, 1.0$ equiv) in $\mathrm{CH}_{2} \mathrm{Cl}_{2}(250 \mu \mathrm{L}, 0.1 \mathrm{M})$ contained in a $5 \mathrm{~mL}$ vial under $\mathrm{N}_{2}$ was added $i-\mathrm{Pr}_{2} \mathrm{NEt}$ (30 $\mu \mathrm{L}, 0.18 \mathrm{mmol}, 7.0$ equiv), followed by DMSO (20 $\mu \mathrm{L}, 0.3 \mathrm{mmol}, 10$ equiv). After being cooled to $0{ }^{\circ} \mathrm{C}, \mathrm{SO}_{3} \cdot \operatorname{Pyr}(16 \mathrm{mg}, 0.10 \mathrm{mmol}, 4.0$ equiv) was added. The reaction mixture was stirred for $2 \mathrm{~h}$ at $0{ }^{\circ} \mathrm{C}$ and quenched with saturated aqueous $\mathrm{NaHCO}_{3}$ solution $(5 \mathrm{~mL})$. After dilution with brine $(5 \mathrm{~mL})$, the mixture was extracted with EtOAc $(3 \times 5 \mathrm{~mL})$, dried over $\mathrm{Na}_{2} \mathrm{SO}_{4}$, filtered, and concentrated. After evaporation with $\mathrm{PhCH}_{3}(3 \times 2 \mathrm{~mL})$, the crude aldehyde was used without purification for the subsequent Pinnick oxidation.

A solution of the previously described aldehyde $(0.025 \mathrm{mmol}, 1.0$ equiv) in $t$ - $\mathrm{BuOH}(360$ $\mu \mathrm{L}, 14.3 \mathrm{~mL} / \mathrm{mmol})$ and 2-methyl-2-butene $(360 \mu \mathrm{L}, 14.3 \mathrm{~mL} / \mathrm{mmol})$ was prepared in a 5 
$\mathrm{mL}$ vial. After the addition of a solution of aqueous $\mathrm{KH}_{2} \mathrm{PO}_{4}(1.25 \mathrm{M}, 120 \mu \mathrm{L}, 0.15 \mathrm{mmol}$, 6.0 equiv), the reaction mixture was cooled to $-10^{\circ} \mathrm{C}$ in an ice/MeOH bath. $\mathrm{NaClO}_{2}(80 \%$, $14.1 \mathrm{mg}, 0.13 \mathrm{mmol}, 5.0$ equiv) was added in 1 portion to the rapidly stirred mixture. The cooling bath was allowed to expire overnight. The reaction mixture was quenched with aqueous $\mathrm{pH} 4.0$ acetate buffer $(0.1 \mathrm{M}, 5 \mathrm{~mL})$ and brine $(5 \mathrm{~mL})$. After extraction with EtOAc $(3 \times 5 \mathrm{~mL})$, the organic phase was dried over $\mathrm{Na}_{2} \mathrm{SO}_{4}$, filtered, and concentrated. The crude carboxylic acid was purified using a $1 \times 10 \mathrm{~cm}$ silica gel column, eluting with 80/20/1 $\mathrm{PhCH}_{3} / \mathrm{EtOAc} / \mathrm{AcOH}$, collecting $5 \mathrm{~mL}$ fractions. Fractions 4-12 were concentrated and evaporated with $\mathrm{PhCH}_{3}(3 \times 5 \mathrm{~mL})$ to remove residual $\mathrm{AcOH}$, yielding the product as a colorless oil (22 mg, 86\% over 2 steps): $R_{f}=0.35\left(80 / 20 / 1 \mathrm{PhCH}_{3} / \mathrm{EtOAc} / \mathrm{AcOH}\right) ;[a]_{\mathrm{D}}{ }^{20}=$ +6.33 (c= 1.08); ${ }^{1} \mathrm{H}$ NMR (500 MHz, $\left.\mathrm{CDCl}_{3}\right) \delta 7.42-7.41(\mathrm{~m}, 6 \mathrm{H}), 7.33-7.29(\mathrm{~m}, 10 \mathrm{H})$, $7.27-7.23(\mathrm{~m}, 6 \mathrm{H}), 6.88(\mathrm{~d}, J=9.0 \mathrm{~Hz}, 2 \mathrm{H}), 6.14(\mathrm{t}, J=7.0 \mathrm{~Hz}, 1 \mathrm{H}), 4.78(\mathrm{~s}, 1 \mathrm{H}), 4.74-4.69$ $(\mathrm{m}, 5 \mathrm{H}), 4.55(\mathrm{~d}, J=11 \mathrm{~Hz}, 1 \mathrm{H}), 4.52(\mathrm{~s}, 2 \mathrm{H}), 4.45(\mathrm{~d}, J=10.5 \mathrm{~Hz}, 1 \mathrm{H}), 4.30-4.23(\mathrm{~m}, 2 \mathrm{H})$, 4.10 (dddd, $J=11.5,7.5,5.5,5.5 \mathrm{~Hz}, 1 \mathrm{H}), 3.98$ (dd, $J=11.5,2.5 \mathrm{~Hz}, 1 \mathrm{H}), 3.79$ (s, 3H), 3.69 $(\mathrm{q}, J=11 \mathrm{~Hz}, 2 \mathrm{H}), 3.54-3.42(\mathrm{~m}, 3 \mathrm{H}), 3.32(\mathrm{~d}, J=10 \mathrm{~Hz}, 1 \mathrm{H}), 3.24-3.19(\mathrm{~m}, 1 \mathrm{H}), 3.17(\mathrm{~d}, J$ $=9.5 \mathrm{~Hz}, 1 \mathrm{H}), 3.11-3.06(\mathrm{~m}, 1 \mathrm{H}), 2.80(\mathrm{~d}, J=16.5 \mathrm{~Hz}, 1 \mathrm{H}), 2.72(\mathrm{~d}, J=15.5 \mathrm{~Hz}, 1 \mathrm{H})$, 2.69-2.61 (m, 2H), $2.51(\mathrm{~d}, J=8.0 \mathrm{~Hz}, 1 \mathrm{H}), 2.27-2.22(\mathrm{~m}, 3 \mathrm{H}), 2.15(\mathrm{q}, J=12.5 \mathrm{~Hz}, 1 \mathrm{H})$, $2.08(\mathrm{dd}, J=14.5,7.0 \mathrm{~Hz}, 1 \mathrm{H}), 2.03(\mathrm{t}, J=12.5 \mathrm{~Hz}, 1 \mathrm{H}), 1.96(\mathrm{t}, J=12 \mathrm{~Hz}, 2 \mathrm{H}), 1.82$ (ddd, $J=15,8.5,2.0 \mathrm{~Hz}, 1 \mathrm{H}), 1.73-1.62(\mathrm{~m}, 2 \mathrm{H}) ;{ }^{13} \mathrm{C} \mathrm{NMR}\left(125 \mathrm{MHz}, \mathrm{CDCl}_{3}\right) \delta 174.5,171.3$, $169.1,159.5,144.3,143.5,142.3,137.6,137.3,130.3,129.7,128.8,128.7,128.4,128.1$, 128.1, 128.0, 127.4, 114.1, 110.7, 109.1, 95.0, 87.2, 83.4, 76.8, 75.7, 75.1, 74.9, 73.2, 72.0, 70.2, 69.8, 65.9, 64.0, 55.5, 42.8, 41.9, 41.2, 41.0, 40.2, 39.9, 37.7, 34.1, 27.2; DEPT (125 $\left.\mathrm{MHz}, \mathrm{CDCl}_{3}\right)_{\mathrm{CH}_{3}} \delta 55.5 ; \mathrm{CH}_{2} \delta 110.7,109.1,95.0,72.0,70.2,69.8,65.9,64.0,42.8,41.9$, 41.2, 41.0, 40.2, 39.9, 37.7, 34.1, 27.2; CH $\delta 137.4,129.7,128.8,128.7,128.1,128.0,127.4$, $114.1,76.8,75.7,75.1,74.9,73.2$;C $\delta 174.5,171.3,169.1,159.5,144.3,143.5,142.3$, 137.6, 130.3, 128.4, 128.1, 87.2, 83.4; IR (neat) 3065, 2959, 2894, 1756, 1711, 1653, 1612, 1514, 1449, 1369, 1249, 1176, 1080, 1043, 900, 824, 748, $701 \mathrm{~cm}^{-1}$; HRMS (ESI) calcd 1043.4558 for $\mathrm{C}_{62} \mathrm{H}_{68} \mathrm{O}_{13} \mathrm{Na}(\mathrm{M}+\mathrm{Na})$, found 1043.4554 .

Macrolactone (28).-To a $5 \mathrm{~mL}$ vial containing carboxylic acid 27 (22 $\mathrm{mg}, 0.02 \mathrm{mmol}$, 1.0 equiv) was added 50:50 $\mathrm{Et}_{2} \mathrm{O} / \mathrm{HCOOH}(2.3 \mathrm{~mL}, 105 \mathrm{~mL} / \mathrm{mmol})$. The vial was flushed with $\mathrm{N}_{2}$ and the mixture stirred for $3 \mathrm{~h}$ at $\mathrm{rt}$. The solvent was evaporated and the crude product was azeotroped with $\mathrm{PhCH}_{3}(3 \times 5 \mathrm{~mL})$. The product was purified using a $1 \times 10 \mathrm{~cm}$ silica gel column, eluting with 50/45/5 hexanes/EtOAc/MeOH, collecting $5 \mathrm{~mL}$ fractions. Fractions 4-22 were concentrated, yielding the product as a clear oil which was used without further characterization.

The previously prepared seco-acid was dried overnight under high vacuum in a $5 \mathrm{~mL}$ vial. The seco-acid was taken up in THF $(820 \mu \mathrm{L}, 0.03 \mathrm{M})$ and $\mathrm{Et}_{3} \mathrm{~N}(20 \mu \mathrm{L}, 0.13 \mathrm{mmol}, 6.0$ equiv) was added to the stirred solution under $\mathrm{N}_{2}$. After being cooled to $0{ }^{\circ} \mathrm{C}$, a solution of 2,4,6-trichlorobenzoyl chloride in THF $(0.1 \mathrm{M}, 660 \mu \mathrm{L}, 0.066 \mathrm{mmol}, 3.0$ equiv) was added dropwise. After being stirred for $5 \mathrm{~min}$ at $0{ }^{\circ} \mathrm{C}$, the mixture was then stirred at $\mathrm{rt}$ for $3 \mathrm{~h}$. The resulting solution was taken up in $\mathrm{PhCH}_{3}(14 \mathrm{~mL})$ in a $25 \mathrm{~mL}$ gastight syringe. This solution was then added over $16 \mathrm{~h}$ via syringe pump at $0.875 \mathrm{~mL} / \mathrm{h}$ to a stirring solution of DMAP (54 mg, 0.44 mmol, 20 equiv) in $\mathrm{PhCH}_{3}\left(14 \mathrm{~mL}\right.$ ) contained in a $50 \mathrm{~mL}$ flask under $\mathrm{N}_{2}$ that 
was heated at $40{ }^{\circ} \mathrm{C}$. This produced a final reactant concentration of $0.0008 \mathrm{M}$. After the addition was complete, $\mathrm{PhCH}_{3}(1.0 \mathrm{~mL})$ was taken up in the syringe and added over $1 \mathrm{~h}$ to complete the transfer. After being stirred for $3 \mathrm{~h}$ at $40{ }^{\circ} \mathrm{C}$, the reaction mixture was diluted with brine $(50 \mathrm{~mL})$, extracted with EtOAc $(3 \times 10 \mathrm{~mL})$, dried over $\mathrm{Na}_{2} \mathrm{SO}_{4}$, filtered, and concentrated. The crude product was purified using a $1 \times 10 \mathrm{~cm}$ silica gel column, eluting with 50\% EtOAc/hexanes, collecting $5 \mathrm{~mL}$ fractions. Fractions $2-7$ were concentrated to yield the product as a colorless oil $\left(9.2 \mathrm{mg}, 55 \%\right.$ over 2 steps): $R_{f}=0.52(50 \%$ EtOAc/ hexanes); $[a]_{\mathrm{D}}{ }^{20}=+16.1(c=0.460) ;{ }^{1} \mathrm{H}$ NMR $\left(500 \mathrm{MHz}, \mathrm{CDCl}_{3}\right) \delta 7.35-7.28(\mathrm{~m}, 5 \mathrm{H})$, $7.25(\mathrm{~d}, J=8.5 \mathrm{~Hz}, 2 \mathrm{H}), 6.90(\mathrm{~d}, J=8.5 \mathrm{~Hz}, 2 \mathrm{H}), 6.17(\mathrm{t}, J=8.0 \mathrm{~Hz}, 1 \mathrm{H}), 4.95(\mathrm{~d}, J=6.0$ $\mathrm{Hz}, 1 \mathrm{H}), 4.78(\mathrm{~d}, J=8.5 \mathrm{~Hz}, 1 \mathrm{H}), 4.78(\mathrm{~s}, 1 \mathrm{H}), 4.72-4.71(\mathrm{~m}, 2 \mathrm{H}), 4.66(\mathrm{~d}, J=11.0 \mathrm{~Hz}, 1 \mathrm{H})$, $4.64(\mathrm{~s}, 1 \mathrm{H}), 4.62-4.46(\mathrm{~m}, 4 \mathrm{H}), 4.39(\mathrm{~d}, J=11 \mathrm{~Hz}, 1 \mathrm{H}), 4.19-4.14(\mathrm{~m}, 1 \mathrm{H}), 4.01(\mathrm{~d}, J=$ $11.5 \mathrm{~Hz}, 1 \mathrm{H}), 4.00-3.95(\mathrm{~m}, 1 \mathrm{H}), 3.88(\mathrm{ddd}, J=11.5,11.5,2.0 \mathrm{~Hz}, 2 \mathrm{H}), 3.81(\mathrm{~s}, 3 \mathrm{H}), 3.67$ (d, $J=10 \mathrm{~Hz}, 1 \mathrm{H}), 3.63-3.57(\mathrm{~m}, 1 \mathrm{H}), 3.55-3.49(\mathrm{~m}, 1 \mathrm{H}), 3.38-3.34(\mathrm{~m}, 2 \mathrm{H}), 2.89$ (d, $J=$ $15.5 \mathrm{~Hz}, 1 \mathrm{H}), 2.81$ (dd, $J=15.5,4.0 \mathrm{~Hz}, 1 \mathrm{H}), 2.74-2.62(\mathrm{~m}, 1 \mathrm{H}), 2.59$ (d, $J=13 \mathrm{~Hz}, 1 \mathrm{H})$, $2.55(\mathrm{~d}, J=16 \mathrm{~Hz}, 1 \mathrm{H}), 2.45(\mathrm{dd}, J=14.5,9.5 \mathrm{~Hz}, 1 \mathrm{H}), 2.34(\mathrm{~d}, J=13.5 \mathrm{~Hz}, 1 \mathrm{H}), 2.27(\mathrm{t}, J$ $=12 \mathrm{~Hz}, 1 \mathrm{H}), 2.21-2.18(\mathrm{~m}, 1 \mathrm{H}), 2.15(\mathrm{t}, J=12 \mathrm{~Hz}, 2 \mathrm{H}), 1.96(\mathrm{t}, J=12.5 \mathrm{~Hz}, 2 \mathrm{H}), 1.88(\mathrm{t}, J$ $=12.5 \mathrm{~Hz}, 1 \mathrm{H}), 1.70(\mathrm{~m}, 2 \mathrm{H}), 1.63-1.60(\mathrm{~m}, 1 \mathrm{H}) ;{ }^{13} \mathrm{C} \mathrm{NMR}\left(125 \mathrm{MHz}, \mathrm{CDCl}_{3}\right) \delta 170.4$, $168.8,159.5,144.4,142.4,138.5,137.8,130.4,129.4,128.7,128.1,128.0,128.0,127.9$, 114.2, 110.6, 109.1, 94.6, 81.5, 77.6, 76.2, 74.9, 74.7, 73.0, 72.4, 69.9, 66.6, 65.3, 62.6, 55.5, 43.1, 42.4, 41.4, 41.2, 40.8, 40.4, 37.0, 34.7, 26.5; DEPT (125 MHz, $\left.\mathrm{CDCl}_{3}\right) \mathrm{CH}_{3} \delta$ $55.5 ; \mathrm{CH}_{2} \delta 110.6,109.1,94.6,72.4,69.9,66.6,65.3,62.3,62.5,43.1,42.4,41.4,41.2$, $40.8,40.4,37.0,34.7,26.5$; CH $\delta 138.5,129.4,128.7,128.0,114.1,77.6,76.2,74.9,74.7$, 73.0; C $\delta 170.4,168.8,159.5,144.4,142.4,137.8,130.4,128.1,128.0,127.9,81.5$. IR (neat) 2940, 2886, 1764, 1742, 1612, 1514, 1380, 1249, 1176, 1120, 1047, 892, 821, $740 \mathrm{~cm}$ ${ }^{-1}$ : HRMS (ESI) calcd 783.3356 for $\mathrm{C}_{43} \mathrm{H}_{52} \mathrm{NaO}_{12}(\mathrm{M}+\mathrm{Na}$ ), found 783.3367.

Merle 47.-To a stirring solution of macrolactone 28 (5.3 $\mathrm{mg}, 0.007 \mathrm{mmol}, 1.0$ equiv) in $\mathrm{CH}_{2} \mathrm{Cl}_{2}(700 \mu \mathrm{L}, 0.01 \mathrm{M})$ contained in a $5 \mathrm{~mL}$ vial was added $\mathrm{H} 2 \mathrm{O}(20 \mu \mathrm{L})$. After being cooled to $0{ }^{\circ} \mathrm{C}$, DDQ $\left(16.1 \mathrm{mg}, 0.07 \mathrm{mmol}, 10\right.$ equiv) was added. After being stirred at $0{ }^{\circ} \mathrm{C}$ for $2 \mathrm{~h}$, the reaction mixture was quenched with saturated aqueous $\mathrm{NaHCO}_{3}$ solution (25 $\mathrm{mL})$ and extracted with $\mathrm{CH}_{2} \mathrm{Cl}_{2}(3 \times 10 \mathrm{~mL})$. The organic phase was dried over $\mathrm{Na}_{2} \mathrm{SO}_{4}$, filtered, and concentrated. After being dried under high vacuum for $1 \mathrm{~h}$, the crude product was used without purification for the subsequent deprotection step.

To the aforementioned product contained in a $5 \mathrm{~mL}$ vial, a solution of $\mathrm{LiBF}_{4}$ in 25:1 $\mathrm{MeCN} / \mathrm{H}_{2} \mathrm{O}\left(0.25 \mathrm{M}, 1.26 \mathrm{~mL}, 45\right.$ equiv) was added. The vial was flushed with $\mathrm{N}_{2}$, capped, and stirred at $80^{\circ} \mathrm{C}$ overnight. After being cooled to rt, the reaction mixture was quenched with brine $(10 \mathrm{~mL})$, and extracted with EtOAc $(3 \times 10 \mathrm{~mL})$. After being dried over $\mathrm{Na}_{2} \mathrm{SO}_{4}$, the solution was filtered and concentrated to dryness. The crude product was purified using a $1 \times 5 \mathrm{~cm}$ silica gel column, eluting with 50\% EtOAc/hexanes, collecting $1 \mathrm{~mL}$ fractions.

Fractions 9-50 contained the desired product. The product was purified a second time by the same procedure to yield the desired macrolactone as an oil ( $1.3 \mathrm{mg}, 36 \%$ over 2 steps): $R_{f}=$ $0.08\left(50 \%\right.$ EtOAc/hexanes); $[a]_{\mathrm{D}}{ }^{20}=-6.2(c=0.065) ;{ }^{1} \mathrm{H}$ NMR $\left(500 \mathrm{MHz}, \mathrm{CDCl}_{3}\right) \delta 6.28$ $(\mathrm{t}, J=7.0, \mathrm{~Hz}, 1 \mathrm{H}), 4.61(\mathrm{dd}, J=10,1.5 \mathrm{~Hz}, 2 \mathrm{H}), 4.57(\mathrm{~s}, 2 \mathrm{H}), 4.50(\mathrm{~d}, J=12 \mathrm{~Hz}, 1 \mathrm{H})$, $4.45-4.41$ (m, 1H), 4.36-4.30 (m, 1H), 4.24 (ddd, $J=10.5,10.5,2.5 \mathrm{~Hz}, 1 \mathrm{H}), 4.07$ (d, $J=12$ 
$\mathrm{Hz}, 1 \mathrm{H}), 3.87$ (dd, $J=11.5,2.5 \mathrm{~Hz}, 1 \mathrm{H}), 3.72-3.70(\mathrm{~m}, 2 \mathrm{H}), 3.63(\mathrm{t}, J=10 \mathrm{~Hz}, 1 \mathrm{H}), 3.53-$ $3.48(\mathrm{~m}, 1 \mathrm{H}), 3.43(\mathrm{~m}, 2 \mathrm{H}), 2.92(\mathrm{~d}, J=16 \mathrm{~Hz}, 1 \mathrm{H}),), 2.90-2.85(\mathrm{~m}, 1 \mathrm{H}), 2.83-2.73(\mathrm{~m}$, 2H), $2.69(\mathrm{~d}, J=16 \mathrm{~Hz}, 1 \mathrm{H}), 2.53(\mathrm{~d}, J=13 \mathrm{~Hz}, 1 \mathrm{H}), 2.48(\mathrm{dd}, J=14,9.5 \mathrm{~Hz}, 1 \mathrm{H}), 2.42(\mathrm{~d}$, $J=6.0 \mathrm{~Hz}, 1 \mathrm{H}), 2.37-2.29(\mathrm{~m}, 2 \mathrm{H}), 2.18(\mathrm{t}, J=9.0 \mathrm{~Hz}, 2 \mathrm{H}), 2.07-1.97(\mathrm{~m}, 4 \mathrm{H}), 1.78-1.73$ (m, 1H), 1.70-1.62 (m, 2H); ${ }^{13} \mathrm{C}$ NMR $\left(125 \mathrm{MHz}, \mathrm{CDCl}_{3}\right) \delta 170.4,168.8,143.6,141.9$, 139.2, 127.7, 111.0, 109.6, 83.0, 77.5, 77.0, 76.3, 76.1, 75.5, 65.8, 63.4, 63.2, 43.2, 43.0, 41.9, 41.3, 41.2, 40.6, 37.0, 34.0, 26.9; DEPT (125 MHz, $\left.\mathrm{CDCl}_{3}\right) \mathrm{CH}_{3} \delta \mathrm{CH}_{2} \delta 111.0$, 109.6, 77.5, 75.4, 65.8, 63.4, 63.2, 43.2, 41.9, 41.4, 41.2, 40.6, 37.0, 26.9; CH $\delta$ 139.2, 77.0, 76.3, 76.1, 75.4, 65.8; C $\delta 170.4,168.8,143.6,141.9,127.7,83.0$. IR (neat) 3430, 2943, 1754, 1742, 1581, 1382, 1257, 1194, 1081, 1030, 896, $753 \mathrm{~cm}^{-1}$; HRMS (ESI) calcd for $\mathrm{C}_{27} \mathrm{H}_{36} \mathrm{NaO}_{10}(\mathrm{M}+\mathrm{Na})$ 543.2206, found 543.2207.

Aldol (33).-To a solution of $i$ - $\operatorname{Pr}_{2} \mathrm{NH}(3.0 \mathrm{~mL}, 21.5 \mathrm{mmol}, 1.1$ equiv) in THF (15 mL) contained in a $100 \mathrm{~mL}$ flask under $\mathrm{N}_{2}$ at $-78^{\circ} \mathrm{C}$ was added a solution of $n-\mathrm{BuLi}(2.5 \mathrm{M}, 8.6$ $\mathrm{mL}, 21.5 \mathrm{mmol}, 1.1$ equiv). The solution was stirred at $\mathrm{rt}$ for $30 \mathrm{~min}$. After being cooled the solution to $-78^{\circ} \mathrm{C}$, a solution of methyl isobutyrate $(2.2 \mathrm{~mL}, 19.5 \mathrm{mmol}, 1.0$ equiv) in THF $(5 \mathrm{~mL})$ was added via cannula. The solution was stirred for $1.5 \mathrm{~h}$ at $-78{ }^{\circ} \mathrm{C}$, after which a solution of aldehyde 14 (4.4 g, $23.4 \mathrm{mmol}, 1.2$ equiv) in THF ( $5 \mathrm{~mL})$ was added via cannula. The reaction mixture was stirred at $-78{ }^{\circ} \mathrm{C}$ for $2 \mathrm{~h}$. The reaction mixture was then quenched with saturated aqueous $\mathrm{NaHCO}_{3}$ solution $(50 \mathrm{~mL})$. The mixture was then extracted with $50 \%$ EtOAc/hexanes $(3 \times 15 \mathrm{~mL})$. The organic phase was washed with brine $(2 \times 25 \mathrm{~mL})$ and dried over $\mathrm{Na}_{2} \mathrm{SO}_{4}$. After filtration, the solvent was evaporated. The crude product was purified using a $4 \times 10 \mathrm{~cm}$ silica column, eluting with $10 \%$ EtOAc/hexanes, collecting 10 $\mathrm{mL}$ fractions. Fractions $22-58$ were combined and concentrated to yield the product $(5.9 \mathrm{~g}$, 94\%) as a colorless oil: $\mathrm{R}_{\mathrm{f}}=0.54\left(25 \%\right.$ EtOAc/hexanes); ${ }^{1} \mathrm{H}$ NMR $\left(500 \mathrm{MHz}, \mathrm{CDCl}_{3}\right) \delta$ 3.94 (ddd, $J=8.0,6.0,3.0 \mathrm{~Hz}, 1 \mathrm{H}), 3.89$ (dd, $J=10,5.0 \mathrm{~Hz}, 1 \mathrm{H}), 3.85-3.81(\mathrm{~m}, 1 \mathrm{H}), 3.70$ (s, 3H), $3.43(\mathrm{~d}, J=3.0 \mathrm{~Hz}, 1 \mathrm{H}), 1.59$ (t, $J=4.5 \mathrm{~Hz}, 2 \mathrm{H}), 1.20(\mathrm{~s}, 3 \mathrm{H}), 1.17$ (s, 3H), 0.90 (s, 9H), 0.08 (s, 6H); ${ }^{13} \mathrm{C}$ NMR (125 MHz, $\left.\mathrm{CDCl}_{3}\right) \delta 178.0,76.3,62.5,52.1,47.3,33.9,26.1$, 21.5, 20.8, 18.4, -5.3; DEPT (125 MHz, $\left.\mathrm{CDCl}_{3}\right) \mathrm{CH}_{3} \delta 52.1,26.1,21.5,20.7,-5.3 ; \mathrm{CH}_{2} \delta$ 62.9, 33.8; CH $\delta 76.3$; C $\delta 178.0,47.3,18.4$; IR (neat) 3508, 2954, 2857, 1732, 1471, 1388 , $1256,1090 \mathrm{~cm}^{-1}$; HRMS (ESI) calcd 313.1811 for $\mathrm{C}_{14} \mathrm{H}_{30} \mathrm{O}_{4} \mathrm{NaSi}(\mathrm{M}+\mathrm{Na})$, found 313.1809 .

Ester (32).-To a stirring solution of ester $33(5.9 \mathrm{~g}, 20 \mathrm{mmol}, 1.0$ equiv) in toluene (81 $\mathrm{mL}, 0.25 \mathrm{M}$ ) contained in a $250 \mathrm{~mL}$ flask under $\mathrm{N}_{2}$ was added $\mathrm{Et}_{3} \mathrm{~N}(5.6 \mathrm{~mL}, 40 \mathrm{mmol}, 2.0$ equiv). $\mathrm{MsCl}$ (1.9 mL, $24 \mathrm{mmol}, 1.2$ equiv) was then slowly added. A white precipitate immediately formed; the reaction mixture was then stirred overnight at rt. The reaction mixture was then quenched with saturated aqueous $\mathrm{NaHCO}_{3}$ solution $(150 \mathrm{~mL})$. The mixture was then extracted with $50 \%$ EtOAc/hexanes $(3 \times 25 \mathrm{~mL})$. The organic phase was then washed with brine $(100 \mathrm{~mL})$ and dried over $\mathrm{Na}_{2} \mathrm{SO}_{4}$. After filtration, the solution was concentrated and the crude mesylate used as is.

To a stirring solution of the previously prepared mesylate in DMSO (200 mL, $0.1 \mathrm{M})$ contained in a $500 \mathrm{~mL}$ flask fitted with a reflux condenser under $\mathrm{N}_{2}$ was added DBU (7.5 $\mathrm{mL}, 50 \mathrm{mmol}, 2.5$ equiv) The reaction mixture was heated at $115{ }^{\circ} \mathrm{C}$ overnight. After being 
cooled to rt, the reaction mixture was quenched with saturated aqueous $\mathrm{NaHCO}_{3}$ solution $(250 \mathrm{~mL})$ and $\mathrm{H}_{2} \mathrm{O}(250 \mathrm{~mL})$. The mixture was extracted with $50 \%$ EtOAc/hexanes $(3 \times 100$ $\mathrm{mL})$. The organic phase was washed with brine $(200 \mathrm{~mL})$ and dried over $\mathrm{Na}_{2} \mathrm{SO}_{4}$. After filtration and concentration, the product was purified using a $4 \times 11 \mathrm{~cm}$ silica gel column, eluted with 5\% EtOAc/hexanes, collecting $10 \mathrm{~mL}$ fractions. Fractions $28-44$ were combined and concentrated to yield the product $(3.5 \mathrm{~g}, 64 \%)$ as a colorless oil, spectroscopically identical to the material previously reported: ${ }^{22} \mathrm{R}_{\mathrm{f}}=0.76$ (25\% EtOAc/hexanes); ${ }^{1} \mathrm{H}$ NMR $\left(500 \mathrm{MHz}, \mathrm{CDCl}_{3}\right) 5.84(\mathrm{dt}, J=15.5,2.0 \mathrm{~Hz}, 1 \mathrm{H}), 5.59(\mathrm{dt}, J=15.5,5.0 \mathrm{~Hz}, 1 \mathrm{H}), 4.18(\mathrm{dd}$, $J=5.0,1.5, \mathrm{~Hz}, 2 \mathrm{H}), 3.67(\mathrm{~s}, 3 \mathrm{H}), 1.31(\mathrm{~s}, 6 \mathrm{H}), 0.91(\mathrm{~s}, 9 \mathrm{H}), 0.07(\mathrm{~s}, 6 \mathrm{H}) ;{ }^{13} \mathrm{C}$ NMR $(125$ $\left.\mathrm{MHz}, \mathrm{CDCl}_{3}\right) \delta 177.1,134.8,128.0,64.0,52.2,44.1,26.2,25.2,18.6,-4.9$.

Aldehyde (34).-To a stirring solution of ester 32 (3.24 g, 8.7 mmol, 1.0 equiv) in $\mathrm{Et}_{2} \mathrm{O}$ $(43 \mathrm{~mL}, 0.2 \mathrm{M})$ contained in a $100 \mathrm{~mL}$ flask under $\mathrm{N}_{2}$ at $0{ }^{\circ} \mathrm{C}$ was added $\mathrm{LiAlH}_{4}(362 \mathrm{mg}$, $9.6 \mathrm{mmol}, 1.1$ equiv). After being stirred for $1 \mathrm{~h}$, the reaction mixture was quenched by the slow addition of EtOAc $(5 \mathrm{~mL})$, followed by a saturated aqueous solution of potassium sodium tartrate $(50 \mathrm{~mL})$. After being stirred for $30 \mathrm{~min}$, the mixture was extracted with $50 \%$ EtOAc/hexanes $(3 \times 25 \mathrm{~mL})$, dried over $\mathrm{Na}_{2} \mathrm{SO}_{4}$, filtered, and concentrated. The crude alcohol was used without purification for the subsequent oxidation step.

To a stirring solution of the aforementioned alcohol ( $2.90 \mathrm{~g}, 8.7 \mathrm{mmol}, 1.0$ equiv) in $\mathrm{CH}_{2} \mathrm{Cl}_{2}$ $(87 \mathrm{~mL}, 0.1 \mathrm{M})$ contained in a $250 \mathrm{~mL}$ flask under $\mathrm{N}_{2}$ was added DMSO $(6.2 \mathrm{~mL}, 87 \mathrm{mmol}$, 10.0 equiv) and $i$ - $\operatorname{Pr}_{2} \mathrm{NEt}\left(10.6 \mathrm{~mL}, 61 \mathrm{mmol}, 7.0\right.$ equiv). After being cooled to $0{ }^{\circ} \mathrm{C}$, $\mathrm{SO}_{3} \cdot \operatorname{Pyr}(5.54 \mathrm{~g}, 35 \mathrm{mmol}, 4.0$ equiv) was added to the stirring solution. After being stirred for $1 \mathrm{~h}$ at $0{ }^{\circ} \mathrm{C}$, the reaction was quenched with saturated aqueous $\mathrm{NaHCO}_{3}$ solution $(100$ $\mathrm{mL})$. After being stirred at $\mathrm{rt}$ for $20 \mathrm{~min}$, the mixture was extracted with $\mathrm{CH}_{2} \mathrm{Cl}_{2}(3 \times 30$ $\mathrm{mL})$. The organic phase was washed with brine $(50 \mathrm{~mL})$, dried over $\mathrm{Na}_{2} \mathrm{SO}_{4}$, filtered, and concentrated. The crude aldehyde was purified using a $4 \times 10 \mathrm{~cm}$ silica gel column, eluting with $10 \%$ EtOAc/hexanes, collecting $10 \mathrm{~mL}$ fractions. Product bearing fractions $16-36$ were combined and concentrated to yield the aldehyde ( $2.78 \mathrm{~g}, 97 \%$, over 2 steps) as a colorless oil: $\mathrm{R}_{\mathrm{f}}=\left(25 \%\right.$ EtOAc/hexanes); ${ }^{1} \mathrm{H}$ NMR $\left(500 \mathrm{MHz}, \mathrm{CDCl}_{3}\right) \delta 9.38(\mathrm{~s}, 1 \mathrm{H}), 5.64(\mathrm{~s}, 2 \mathrm{H})$, $4.20(\mathrm{t}, J=1.0 \mathrm{~Hz}, 2 \mathrm{H}), 1.20$ (s, 6H), $0.91(\mathrm{~s}, 9 \mathrm{H}), 0.07(\mathrm{~s}, 6 \mathrm{H}) ;{ }^{13} \mathrm{C}$ NMR $(125 \mathrm{MHz}$, $\left.\mathrm{CDCl}_{3}\right) \delta 202.8,131.4,131.3,63.8,59.9,48.4,26.2,21.6,18.6,-5.0$; DEPT (125 MHz, $\left.\mathrm{CDCl}_{3}\right) \mathrm{CH}_{3} \delta 26.2,21.7,-4.9 ; \mathrm{CH} \delta 63.9 ; \mathrm{CH} \delta 202.8,131.5,131.3 ; \mathrm{C} \delta 48.6,18.7$; IR (neat) 2930, 2858, 1730, 1472, 1362, 1255, 1107, $837 \mathrm{~cm}^{-1}$ : HRMS (ESI) calcd 265.1600 for $\mathrm{C}_{13} \mathrm{H}_{26} \mathrm{O}_{2} \mathrm{SiNa}(\mathrm{M}+\mathrm{Na})$, found 265.1608.

Diene (35).-To a $250 \mathrm{~mL}$ flask was added $\mathrm{KO} t \mathrm{Bu}$ (1.72 g, $15.3 \mathrm{mmol}, 1.8$ equiv), followed by methyl triphenylphosphonium bromide ( $6.1 \mathrm{~g}, 17 \mathrm{mmol}, 2.0$ equiv). After being flushed with $\mathrm{N}_{2}$, the mixture was cooled to $0{ }^{\circ} \mathrm{C}$ and THF $(75 \mathrm{~mL})$ was added. The yellow mixture was stirred at $0{ }^{\circ} \mathrm{C}$ for $30 \mathrm{~min}$. A solution of aldehyde $\mathbf{3 4}(2.06 \mathrm{~g}, 8.5 \mathrm{mmol}, 1.0$ equiv) in THF $(5 \mathrm{~mL})$ was then added via cannula, using THF $(5.0 \mathrm{~mL})$ to complete the transfer. After being stirred at $\mathrm{rt}$ for $30 \mathrm{~min}$, the reaction mixture was quenched with saturated aqueous $\mathrm{NH}_{4} \mathrm{Cl}$ solution $(100 \mathrm{~mL})$. The mixture was extracted with $50 \% \mathrm{EtOAc/}$ hexanes $(3 \times 25 \mathrm{~mL})$. The organic phase was washed with brine $(100 \mathrm{~mL})$, dried over $\mathrm{Na}_{2} \mathrm{SO}_{4}$, filtered, and concentrated. The crude olefin was purified using a $2 \times 10 \mathrm{~cm}$ silica 
gel column, eluting with $10 \%$ EtOAc/hexanes, collecting $5 \mathrm{~mL}$ fractions. Fractions $2-14$ were combined and concentrated to yield the desired product $(1.92 \mathrm{~g}, 94 \%)$ as a colorless oil: $R_{f}=0.88$ (10\% EtOAc/hexanes); ${ }^{1} \mathrm{H}$ NMR $\left(500 \mathrm{MHz}, \mathrm{CDCl}_{3}\right) \delta 5.83$ (dd, $J=17,10 \mathrm{~Hz}$, $1 \mathrm{H}), 5.64(\mathrm{dt}, J=15.5,1.5, \mathrm{~Hz}, 1 \mathrm{H}), 5.48(\mathrm{dt}, J=10.5,5.5 \mathrm{~Hz}, 1 \mathrm{H}), 4.94$ (ddd, $J=17.5$, $10.5,1.0 \mathrm{~Hz}, 2 \mathrm{H}), 4.17$ (dd, $J=5.5,1.5 \mathrm{~Hz}, 2 \mathrm{H}), 1.12(\mathrm{~s}, 6 \mathrm{H}), 0.92(\mathrm{~s}, 9 \mathrm{H}), 0.07(\mathrm{~s}, 6 \mathrm{H}) ;{ }^{13} \mathrm{C}$ NMR (125 MHz, $\left.\mathrm{CDCl}_{3}\right) \delta 147.3,139.3,126.1,110.8,64.4,59.9,27.1,26.2,18.7,-4.8$; DEPT (125 MHz, $\left.\mathrm{CDCl}_{3}\right) \mathrm{CH}_{3} \delta 27.1,26.2,-4.8 ; \mathrm{CH}_{2} \delta 110.7,64.4 ; \mathrm{CH} \delta$ 147.3, 139.3, 126.1; C $\delta 59.9,18.7$; IR (neat) 3084, 2958, 2929, 2858, 1637, 1472, 1386, 1361, 1255, $1106,1068,973,914,837,775,665 \mathrm{~cm}^{-1}$; HRMS (ESI) calcd 263.1807 for $\mathrm{C}_{14} \mathrm{H}_{28} \mathrm{ONaSi}$ $(\mathrm{M}+\mathrm{Na})$, found 263.1805 .

Alcohol (36).-To a stirring solution of olefin 35 (1.60 g, $6.65 \mathrm{mmol}, 1.0$ equiv) in THF $(27 \mathrm{~mL}, 0.25 \mathrm{M})$ contained in a $100 \mathrm{~mL}$ flask was added a solution of 9-BBN in THF $(0.5$ $\mathrm{M}, 20 \mathrm{~mL}, 10.0 \mathrm{mmol}, 1.5$ equiv). The reaction mixture was then placed in an ultrasonic bath for $1 \mathrm{~h}$. The reaction mixture was quenched with $\mathrm{H}_{2} \mathrm{O}(50 \mathrm{~mL})$, followed by an aqueous solution of $\mathrm{NaOH}(1 \mathrm{M}, 50 \mathrm{~mL})$ and chilled in an ice bath; $30 \%$ aqueous $\mathrm{H}_{2} \mathrm{O}_{2}(20 \mathrm{~mL})$ was then added in small portions. The mixture was stirred for $1 \mathrm{~h}$ at $0{ }^{\circ} \mathrm{C}$. The mixture was diluted with brine $(50 \mathrm{~mL})$, followed by extraction with $50 \%$ EtOAc/hexanes $(3 \times 25 \mathrm{~mL})$. The organic phase was washed with brine $(50 \mathrm{~mL})$, dried over $\mathrm{Na}_{2} \mathrm{SO}_{4}$, filtered, and concentrated. The product was purified using a $4 \times 15 \mathrm{~cm}$ silica gel column, eluting with $5 \%$ EtOAc/hexanes until fraction 96 was reached; after this the product was eluted with $25 \%$ EtOAc/hexanes, collecting $5 \mathrm{~mL}$ fractions. Fractions 110-138 were combined and concentrated to yield the product $(1.46 \mathrm{~g}, 85 \%)$ as a colorless oil: $\mathrm{R}_{\mathrm{f}}=0.10(10 \% \mathrm{EtOAc} /$ hexanes); ${ }^{1} \mathrm{H}$ NMR (500 MHz, $\left.\mathrm{CDCl}_{3}\right) \delta 5.66(\mathrm{dt}, J=16,1.5 \mathrm{~Hz}, 1 \mathrm{H}), 5.48(\mathrm{dt}, J=16,5.5$ $\mathrm{Hz}, 1 \mathrm{H}), 4.15$, (dd, $J=5.0,1.5 \mathrm{~Hz}, 2 \mathrm{H}), 3.65(\mathrm{t}, J=7.0 \mathrm{~Hz}, 2 \mathrm{H}), 1.62(\mathrm{t}, J=7.5 \mathrm{~Hz}, 2 \mathrm{H})$, $1.33(\mathrm{~s}, 1 \mathrm{H}), 1.04(\mathrm{~s}, 6 \mathrm{H}), 0.91(\mathrm{~s}, 9 \mathrm{H}), 0.07(\mathrm{~s}, 6 \mathrm{H}) ;{ }^{13} \mathrm{C} \mathrm{NMR}\left(125 \mathrm{MHz}, \mathrm{CDCl}_{3}\right) \delta 140.6$, 126.0, 64.3, 60.4, 45.7, 35.0, 27.7, 26.2, 18.6, -4.9; DEPT (125 MHz, $\left.\mathrm{CDCl}_{3}\right) \mathrm{CH}_{3} \delta 27.7$, $26.2,-4.9 ; \mathrm{CH}_{2} \delta 64.3,60.4,45.6$; $\mathrm{CH} \delta 140.6,125.9$; C $\delta 35.0,18.6$; IR (neat) 3356, 2956, $2857,1472,1387,1362,1255,1107,1060,1024,975,836,776 \mathrm{~cm}^{-1}$; HRMS (ESI) calcd 281.1913 for $\mathrm{C}_{14} \mathrm{H}_{30} \mathrm{O}_{2} \mathrm{NaSi}(\mathrm{M}+\mathrm{Na})$, found 281.1915.

Aldehyde (30).-To a $50 \mathrm{~mL}$ flask, alcohol 36 (500 mg, $1.93 \mathrm{mmol}, 1.0$ equiv) was added. After being flushed with $\mathrm{N}_{2}, \mathrm{CH}_{2} \mathrm{Cl}_{2}(19 \mathrm{~mL}, 0.1 \mathrm{M})$ was added. The solution was chilled to $0{ }^{\circ} \mathrm{C}$, and $i-\operatorname{Pr}_{2} \mathrm{NEt}(2.4 \mathrm{~mL}, 14 \mathrm{mmol}, 7.0$ equiv) was added, followed by DMSO (1.4 mL, $19 \mathrm{mmol}, 10.0$ equiv). To the solution, $\mathrm{SO}_{3}-\operatorname{Pyr}(1.23 \mathrm{~g}, 7.7 \mathrm{mmol}, 4.0$ equiv) was added. The reaction mixture was then stirred at $0{ }^{\circ} \mathrm{C}$ for $1 \mathrm{~h}$. The reaction mixture was then quenched with saturated aqueous $\mathrm{NaHCO}_{3}$ solution $(50 \mathrm{~mL})$. After being stirred for $15 \mathrm{~min}$, the mixture was extracted with $\mathrm{CH}_{2} \mathrm{Cl}_{2}(2 \times 10 \mathrm{~mL})$. The organic phase was dried over $\mathrm{Na}_{2} \mathrm{SO}_{4}$, filtered, and concentrated. The crude product was purified using a $2 \times 15 \mathrm{~cm}$ silica gel column, eluting with 5\% EtOAc/hexanes, collecting $5 \mathrm{~mL}$ fractions. Product containing fractions 10-15 were combined and concentrated to yield the product (377 $\mathrm{mg}, 76 \%$ ) as a colorless oil: $\mathrm{R}_{\mathrm{f}}=0.40$ (10\% EtOAc/hexanes); ${ }^{1} \mathrm{H}$ NMR $\left(500 \mathrm{MHz}, \mathrm{CDCl}_{3}\right) \delta 9.73$ (t, $J=$ $1.8 \mathrm{~Hz}, 1 \mathrm{H}), 5.75(\mathrm{dt}, J=15.5,1.5 \mathrm{~Hz}, 1 \mathrm{H}), 5.53$ (dt, $J=15.5,4.5 \mathrm{~Hz}, 1 \mathrm{H}), 4.17$ (dd, $J=5.0$, $1.5 \mathrm{~Hz}, 2 \mathrm{H}), 2.34$ (d, $J=3.0 \mathrm{~Hz}, 2 \mathrm{H}), 1.16(\mathrm{~s}, 6 \mathrm{H}), 0.91(\mathrm{~s}, 9 \mathrm{H}), 0.07$ (s, 6H); ${ }^{13} \mathrm{C}$ NMR $(125$ $\left.\mathrm{MHz}, \mathrm{CDCl}_{3}\right) \delta 203.5,138.4,127.0,64.0,55.3,35.3,27.9,26.2,18.6,-4.9$; DEPT (125 
$\left.\mathrm{MHz}, \mathrm{CDCl}_{3}\right)_{\mathrm{CH}_{3}} \delta 27.9,26.2,-4.9 ; \mathrm{CH}_{2} \delta 64.0,55.2 ; \mathrm{CH} \delta 203.5,138.3,127.0 ; \mathrm{C} \delta$ 35.3, 18.6; IR (neat) 2958, 2930, 2857, 2731, 1724, 1472, 1388, 1375, 1255, 1108, 1068, 976, 837, 776, $666 \mathrm{~cm}^{-1}$; HRMS (ESI) calcd 279.1756 for $\mathrm{C}_{14} \mathrm{H}_{28} \mathrm{O}_{2} \mathrm{NaSi}(\mathrm{M}+\mathrm{Na})$, found 279.1760 .

Lactone Alcohol (37).-A stirring solution of lactone 12 (750 mg, 1.48, mmol, 1.0 equiv) in $\mathrm{CH}_{2} \mathrm{Cl}_{2}(30 \mathrm{~mL}, 0.05 \mathrm{M})$ contained in a $50 \mathrm{~mL}$ flask at $0{ }^{\circ} \mathrm{C}$ was prepared under $\mathrm{N}_{2}$. To this solution, a 50:50 TFA/TFAA solution in $\mathrm{CH}_{2} \mathrm{Cl}_{2}(1.0 \mathrm{M}, 4.44 \mathrm{~mL}, 4.44 \mathrm{mmol}, 3.0$ equiv) was added dropwise, turning the solution bright yellow in color. After being stirred for $30 \mathrm{~min}$ at $0{ }^{\circ} \mathrm{C}, \mathrm{Et}_{3} \mathrm{~N}(4.1 \mathrm{~mL}, 30 \mathrm{mmol}, 20$ equiv) was added and the mixture was stirred for $5 \mathrm{~min}$. The solution was then transferred to a $250 \mathrm{~mL}$ flask and evaporated with $\mathrm{MeOH}$ $(3 \times 75 \mathrm{~mL})$. The resulting oil was dissolved in $\mathrm{PhCH}_{3}(2.0 \mathrm{~mL})$ and purified using a $3 \times 15$ $\mathrm{cm}$ silica gel column. The column was eluted with $25 \%$ EtOAc/hexanes $(300 \mathrm{~mL}), 50 \%$ EtOAc/hexanes $(200 \mathrm{~mL})$, and $75 \%$ EtOAc/hexanes $(100 \mathrm{~mL})$, collecting $10 \mathrm{~mL}$ fractions. Fractions 46-64 were combined and concentrated to yield the product (342 $\mathrm{mg}, 87 \%$ ) as a light yellow oil: $\mathrm{R}_{\mathrm{f}}=0.29\left(50 \%\right.$ EtOAc/hexanes); $[a]_{\mathrm{D}}{ }^{20}=+2.18(c=6.0) ;{ }^{1} \mathrm{H}$ NMR (500 $\left.\mathrm{MHz}, \mathrm{CHCl}_{3}\right) \delta 7.36-7.34(\mathrm{~m}, 4 \mathrm{H}), 7.32-7.30(\mathrm{~m}, 1 \mathrm{H}), 4.77(\mathrm{dd}, J=9.5,6.5 \mathrm{~Hz}, 2 \mathrm{H}), 4.60$ $(\mathrm{s}, 2 \mathrm{H}), 3.77(\mathrm{~d}, J=12 \mathrm{~Hz}, 1 \mathrm{H}), 3.69(\mathrm{ABq}, J=10.5 \mathrm{~Hz}, \Delta v=36.3 \mathrm{~Hz}, 2 \mathrm{H}), 3.62(\mathrm{~d}, J=$ $14.0 \mathrm{~Hz}, 1 \mathrm{H}), 2.71$ (s, 1H), 2.64 (ddd, $J=14,10,8.0 \mathrm{~Hz}, 2 \mathrm{H}), 2.22-2.16$ (m, 1H), 2.13-2.07 $(\mathrm{m}, 1 \mathrm{H}) ;{ }^{13} \mathrm{C} \mathrm{NMR}\left(125 \mathrm{MHz}, \mathrm{CDCl}_{3}\right) \delta 177.6,137.6,128.7,128.1,128.0,95.1,87.6,70.2$, 70.0, 65.4, 29.4, 25.7; DEPT (125 MHz, $\left.\mathrm{CDCl}_{3}\right) \mathrm{CH}_{3} \delta$; $\mathrm{CH} \delta 95.1,70.2,70.0,65.4,29.4$, 25.7 ; CH $\delta 128.7,128.1,128.0$; C $\delta 177.6,137.6,87.6$; IR (neat) 3454, 2940, 1765, 1605, 1461, 1414, 1382, 1208, 1170, 1110, 1043, 946, 736, $699 \mathrm{~cm}^{-1}$; HRMS (ESI) calcd 289.1052 for $\mathrm{C}_{14} \mathrm{H}_{18} \mathrm{O}_{5} \mathrm{Na}(\mathrm{M}+\mathrm{Na})$, found 289.1052 .

TIPS Ether (31).-To a stirring solution of alcohol 37 (933 mg, $3.5 \mathrm{mmol}, 1.0$ equiv) in $\mathrm{CH}_{2} \mathrm{Cl}_{2}(35 \mathrm{~mL}, 0.1 \mathrm{M})$ contained in a $100 \mathrm{~mL}$ flask under $\mathrm{N}_{2}$ was added 2,6-lutidine (1.2 $\mathrm{mL}, 11 \mathrm{mmol}, 3.0$ equiv), followed by TIPSOTf ( $1.4 \mathrm{~mL}, 5.3 \mathrm{mmol}, 1.5$ equiv). The reaction mixture was stirred overnight at $\mathrm{rt}$, quenched with saturated aqueous $\mathrm{NaHCO}_{3}$ solution (50 $\mathrm{mL})$, and extracted with $\mathrm{CH}_{2} \mathrm{Cl}_{2}(3 \times 15 \mathrm{~mL})$. The organic phase was washed with brine (50 $\mathrm{mL}$ ), dried over $\mathrm{Na}_{2} \mathrm{SO}_{4}$, filtered, and concentrated. The product was purified using a $3 \times 10$ $\mathrm{cm}$ silica gel column, eluting with $15 \%$ EtOAc/hexanes, collecting $10 \mathrm{~mL}$ fractions. Fractions 14-30 were combined and concentrated to yield the product $(1.28 \mathrm{~g}, 86 \%)$ as a colorless oil: $\mathrm{R}_{\mathrm{f}}=0.48(25 \%$ EtOAc/hexanes $) ;[a]_{\mathrm{D}}{ }^{20}=-1.03(c=1.95) ;{ }^{1} \mathrm{H}$ NMR $(500$ $\left.\mathrm{MHz}, \mathrm{CDCl}_{3}\right) \delta 7.38-7.29(\mathrm{~m}, 5 \mathrm{H}), 4.78(\mathrm{dd}, J=10,6.5 \mathrm{~Hz}, 2 \mathrm{H}), 4.61(\mathrm{~s}, 2 \mathrm{H}), 3.81(\mathrm{ABq}, J$ $=10.5 \mathrm{~Hz}, \Delta \mathrm{v}=28 \mathrm{~Hz}, 2 \mathrm{H}), 3.71(\mathrm{dd}, J=17,10.5 \mathrm{~Hz}, 2 \mathrm{H}), 2.68-2.57(\mathrm{~m}, 2 \mathrm{H}), 2.25$ (ddd, $J$ $=13.5,10.5,7.0 \mathrm{~Hz}, 1 \mathrm{H}), 2.14-2.05(\mathrm{~m}, 1 \mathrm{H}), 1.16-1.09(\mathrm{~m}, 3 \mathrm{H}), 1.07(\mathrm{~d}, J=7.0 \mathrm{~Hz}, 18 \mathrm{H})$; ${ }^{13} \mathrm{C}$ NMR $\left(125 \mathrm{MHz}, \mathrm{CDCl}_{3}\right) \delta 177.2,137.8,128.7,128.1,128.0,95.2,87.4,70.6,69.9$, 66.7, 29.5, 26.1, 18.1, 12.5; DEPT (125 MHz, $\left.\mathrm{CDCl}_{3}\right) \mathrm{CH}_{3} \delta 18.1$; CH $\delta 95.2,70.6,69.9$, 66.7, 29.5, 26.1; CH $\delta 128.7,128.1,128.0,12.1$; C $\delta 177.2,137.8,87.4$; IR (neat) 2943, 2866, 1781, 1463, 1382, 1207, 1171, 1116, 1049, 949, 883, 811, 738, $696 \mathrm{~cm}^{-1}$; HRMS (ESI) calcd 445.2386 for $\mathrm{C}_{23} \mathrm{H}_{38} \mathrm{O}_{5} \mathrm{SiNa}(\mathrm{M}+\mathrm{Na})$, found 445.2394.

Enoate (38).-To a solution of lactone 31 ( $150 \mathrm{mg}, 0.36 \mathrm{mmol}, 1.0$ equiv) in THF (3.6 $\mathrm{mL}, 0.1 \mathrm{M})$ in a $10 \mathrm{~mL}$ flask at $-78^{\circ} \mathrm{C}$ was added a solution of LDA $(1.0 \mathrm{M}, 400 \mu \mathrm{L}, 0.4$ 
mmol, 1.1 equiv). After being stirred at $-78{ }^{\circ} \mathrm{C}$ for $0.5 \mathrm{~h}$, a solution $1 \mathrm{M}$ in HMPA and $1 \mathrm{M}$ in $(\mathrm{EtO})_{2} \mathrm{POCl}$ in $\mathrm{THF}(470 \mu \mathrm{L}, 0.47 \mathrm{mmol}, 1.3$ equiv) was added to the reaction mixture. After being stirred for $5 \mathrm{~min}$, the reaction mixture was then warmed to $\mathrm{rt}$ and stirred for $1 \mathrm{~h}$. After being cooled the reaction mixture to $-78^{\circ} \mathrm{C}$, a solution of LDA (1.0 M, $790 \mu \mathrm{L}, 0.79$ mmol, 2.2 equiv) was added. The reaction mixture was stirred at $-78{ }^{\circ} \mathrm{C}$ for $1.5 \mathrm{~h}$. The reaction was then quenched at $-78{ }^{\circ} \mathrm{C}$ with a solution of $\mathrm{AcOH}(1.0 \mathrm{~mL})$ in $\mathrm{Et}_{2} \mathrm{O}(5.0 \mathrm{~mL})$. The mixture was diluted with $\mathrm{Et}_{2} \mathrm{O}(50 \mathrm{~mL})$ and filtered through a $4 \times 1 \mathrm{~cm}$ pad of Celite. The solution was then concentrated to yield the phosphonate as a mixture of diastereomers which were used without further characterization.

To the aforementioned phosphonate ( $65 \mathrm{mg}, 0.12 \mathrm{mmol}, 1.0$ equiv) contained in a $15 \mathrm{~mL}$ flask, 18-crown-6 (159 mg, 0.60 mmol. 5.0 equiv) was added. The flask was flushed with $\mathrm{N}_{2}$ and THF ( $3.0 \mathrm{~mL}, 0.04 \mathrm{M}$ ) was added. After being cooled to $-78{ }^{\circ} \mathrm{C}$, a solution of KHMDS in toluene ( $0.5 \mathrm{M}, 270 \mu \mathrm{L}, 0.13 \mathrm{mmol}, 1.1$ equiv) was added dropwise to the stirring mixture. After being stirred for $30 \mathrm{~min}$ at $-78^{\circ} \mathrm{C}$, a solution of aldehyde $33(37 \mathrm{mg}, 0.15$ mmol, 1.2 equiv) in THF (500 $\mu \mathrm{L}$ ) was added dropwise; the transfer was completed with THF $(500 \mu \mathrm{L})$. The reaction mixture was promptly placed in a $30{ }^{\circ} \mathrm{C}$ water bath and stirred overnight at rt. The reaction mixture was quenched with saturated aqueous $\mathrm{NH}_{4} \mathrm{Cl}$ solution $(10 \mathrm{~mL})$, extracted with EtOAc $(3 \times 10 \mathrm{~mL})$, washed with brine $(25 \mathrm{~mL})$, dried over $\mathrm{Na}_{2} \mathrm{SO}_{4}$, filtered, and concentrated. 1H NMR analysis of the crude product indicated a 5:1 ratio of $Z$ - to $E$-enoates by integration of the enoate proton peaks. The product was purified using a $2 \times 10 \mathrm{~cm}$ silica gel column, eluting with $5 \%$ EtOAc/hexanes, collecting $5 \mathrm{~mL}$ fractions. The product containing fractions were combined and concentrated to yield the product ( $79 \mathrm{mg}, 51 \%$ over 2 steps) as a colorless oil: $\mathrm{R}_{\mathrm{f}}=0.29$ (10\% EtOAc/hexanes); $[a]_{\mathrm{D}}{ }^{20}=-0.69\left(c=1.73, \mathrm{CHCl}_{3}\right) ;{ }^{1} \mathrm{H}$ NMR $\left(500 \mathrm{MHz}, \mathrm{CDCl}_{3}\right) \delta 7.37-7.29(\mathrm{~m}, 5 \mathrm{H}), 6.15$ (dddd, $J=9.5,5.5,2.0,2.0 \mathrm{~Hz}, 1 \mathrm{H}$ ), 5.63 (ddd, $J=15.5,1.5,1.5 \mathrm{~Hz}, 1 \mathrm{H}$ ), 5.48 (ddd, $J=16$, $5.5,5.5 \mathrm{~Hz}, 1 \mathrm{H}), 4.78(\mathrm{dd}, J=8.5,6.5 \mathrm{~Hz}, 2 \mathrm{H}), 4.60(\mathrm{~s}, 2 \mathrm{H}), 4.17(\mathrm{dd}, J=5.5,1.5 \mathrm{~Hz}, 2 \mathrm{H})$, $3.77(\mathrm{ABq}, J=10.5 \mathrm{~Hz}, \Delta \mathrm{v}=23.8 \mathrm{~Hz}, 2 \mathrm{H}), 3.69(\mathrm{~d}, J=1.5 \mathrm{~Hz}, 2 \mathrm{H}), 2.90(\mathrm{dd}, J=17,2.0$ $\mathrm{Hz}, 1 \mathrm{H}), 2.81$ (q, $J=7.5 \mathrm{~Hz}, 1 \mathrm{H}), 2.75-2.67$ (m, 2H), 1.15-1.04 (m, $27 \mathrm{H}), 0.92(\mathrm{~s}, 9 \mathrm{H})$, $0.08(\mathrm{~s}, 6 \mathrm{H}) ;{ }^{13} \mathrm{C}$ NMR $\left(125 \mathrm{MHz}, \mathrm{CDCl}_{3}\right) \delta 169.3,140.9,139.8,137.8,128.6,128.1$, 128.0, 126.5, 126.4, 95.2, 83.5, 70.0, 69.8, 65.9, 64.4, 39.8, 36.5, 33.5, 27.3, 26.2, 18.6, 18.1, 12.1, -4.8; DEPT (125 MHz, $\left.\mathrm{CDCl}_{3}\right) \mathrm{CH}_{3} \delta 27.2,26.2,18.1,-4.8 ; \mathrm{CH}_{2} \delta 95.2,70.0$, $69.8,65.9,64.4,39.9,33.5$; CH $\delta 140.9,139.8,128.6,128.1,128.0,126.5,12.1$; C $\delta 169.3$, 137.8, 126.4, 83.5, 26.5, 18.6; IR (neat) 2957, 2866, 1761, 1671, 1463, 1367, 1254, 1117, $1049,882,837,777,684 \mathrm{~cm}^{-1}$; HRMS (ESI) calcd 683.4139 for $\mathrm{C}_{37} \mathrm{H}_{64} \mathrm{O}_{6} \mathrm{NaSi}_{2}(\mathrm{M}+\mathrm{Na})$, found 683.4139 .

Alcohol (39).-To a $25 \mathrm{~mL}$ flask containing enoate 38 (133 mg, $0.20 \mathrm{mmol}, 1.0$ equiv) was added 3:1:1 AcOH/THF/ $\mathrm{H}_{2} \mathrm{O}(10 \mathrm{~mL})$. The flask was stoppered and stirred in an oil bath at $45^{\circ} \mathrm{C}$ for $1 \mathrm{~h}$. Upon cooling to rt, the reaction mixture was slowly added to a stirring saturated aqueous $\mathrm{NaHCO}_{3}$ solution $(100 \mathrm{~mL})$. The mixture was extracted with EtOAc $(3 \times$ $15 \mathrm{~mL})$, washed with saturated aqueous $\mathrm{NaHCO}_{3}$ solution $(50 \mathrm{~mL})$ and brine $(50 \mathrm{~mL})$. The organic phase was then dried over $\mathrm{Na}_{2} \mathrm{SO}_{4}$, filtered, and concentrated. The crude product was purified using a $2 \times 10 \mathrm{~cm}$ silica gel column, eluting with $25 \%$ EtOAc/hexanes, collecting $5 \mathrm{~mL}$ fractions. Fractions $10-25$ were combined and concentrated to yield the 
product (91 mg, 83\%) as a colorless oil: $\mathrm{R}_{\mathrm{f}}=0.15\left(25 \%\right.$ EtOAc/hexanes); $[a]_{\mathrm{D}}^{20}=-5.4(c=$ $\left.0.50, \mathrm{CHCl}_{3}\right) ;{ }^{1} \mathrm{H}$ NMR $\left(500 \mathrm{MHz}, \mathrm{CDCl}_{3}\right) \delta 7.38-7.29(\mathrm{~m}, 5 \mathrm{H}), 6.14$ (dddd, $J=10,7.5$, $5.0,2.5 \mathrm{~Hz}, 1 \mathrm{H}), 5.69(\mathrm{dd}, J=15.5,1.5 \mathrm{~Hz}, 1 \mathrm{H}), 5.56(\mathrm{dt}, J=16,5.5 \mathrm{~Hz}, 1 \mathrm{H}), 4.78(\mathrm{dd}, J=$ $8.5,6.0 \mathrm{~Hz}, 2 \mathrm{H}), 4.60(\mathrm{~s}, 2 \mathrm{H}), 4.12(\mathrm{dd}, J=6.0,1.0 \mathrm{~Hz}, 2 \mathrm{H}), 3.77(\mathrm{ABq}, J=10.5 \mathrm{~Hz}, \Delta \mathrm{v}=$ $21 \mathrm{~Hz}, 2 \mathrm{H}), 3.69$ (dd, $J=13,11 \mathrm{~Hz}, 2 \mathrm{H}), 2.91$ (dd, $J=16,2.0 \mathrm{~Hz}, 1 \mathrm{H}), 2.85$ (dddd, $J=15.5$, 8.0, 3.5, $2.0 \mathrm{~Hz}, 1 \mathrm{H}), 2.74(\mathrm{dd}, J=16,2.0 \mathrm{~Hz}, 1 \mathrm{H}), 2.67$ (dddd, $J=15,9.5,7.5,2.0 \mathrm{~Hz}, 1 \mathrm{H}$ ), 1.12-1.07 (m, 3H), 1.05 (s, $18 \mathrm{H}), 1.04(\mathrm{~s}, 6 \mathrm{H}) ;{ }^{13} \mathrm{C} \mathrm{NMR}\left(125 \mathrm{MHz}, \mathrm{CDCl}_{3}\right) \delta 169.4$, $141.8,140.5,137.8,128.7,128.1,128.0,126.8,126.1,95.2,83.6,70.0,69.8,65.9,64.1$, 39.7, 36.7, 33.5, 27.3, 27.1, 18.1, 12.1; DEPT (125 MHz, $\left.\mathrm{CDCl}_{3}\right) \mathrm{CH}_{3} \delta 27.3,27.1,18.1$; $\mathrm{CH}_{2} \delta 95.2,70.0,69.8,65.9,64.1,39.7,33.5$; $\mathrm{CH} \delta 141.8,140.5,128.7,128.1,128.0$, 126.1, 12.1; C $\delta 169.4,137.8,126.1,83.6,36.7$; IR (neat) 3464, 2943, 2866, 1757, 1684, $1653,1464,1383,1368,1210,1170,1117,1046,973,882,801,734,682 \mathrm{~cm}^{-1}$; HRMS (ESI) calcd 569.3274 for $\mathrm{C}_{31} \mathrm{H}_{50} \mathrm{O}_{6} \mathrm{NaSi}(\mathrm{M}+\mathrm{Na})$, found 569.3273 .

Aldehyde (29).-To a solution of alcohol 39 (91 mg, $0.17 \mathrm{mmol}, 1.0$ equiv) in $\mathrm{CH}_{2} \mathrm{Cl}_{2}$ (3.3 mL, $0.05 \mathrm{M})$ contained in a $15 \mathrm{~mL}$ flask under $\mathrm{N}_{2}$, was added DMSO $(120 \mu \mathrm{L}, 1.7$ mmol, 10 equiv), followed by $i-\operatorname{Pr}_{2} \mathrm{NEt}(210 \mu \mathrm{L}, 1.2 \mathrm{mmol}, 7.0$ equiv). After being cooled to $0{ }^{\circ} \mathrm{C}, \mathrm{SO}_{3} \cdot \mathrm{Pyr}(108 \mathrm{mg}, 0.68 \mathrm{mmol}, 4.0$ equiv) was added. The reaction mixture was stirred at $0{ }^{\circ} \mathrm{C}$ for $1 \mathrm{~h}$ and then quenched with saturated aqueous $\mathrm{NaHCO}_{3}$ solution $(25 \mathrm{~mL})$. The mixture was extracted with $\mathrm{CH}_{2} \mathrm{Cl}_{2}(3 \times 10 \mathrm{~mL})$, dried over $\mathrm{Na}_{2} \mathrm{SO}_{4}$, filtered, and concentrated. The product was purified using a $2 \times 10 \mathrm{~cm}$ silica column, eluting with $15 \%$ EtOAc/hexanes, collecting $5 \mathrm{~mL}$ fractions. Fractions 8-20 were combined and concentrated to yield the product $(60 \mathrm{mg}, 66 \%)$ as a colorless oil: $\mathrm{R}_{\mathrm{f}}=0.38$ (25\% EtOAc/hexanes); $[a]_{\mathrm{D}}{ }^{20}=-59.4\left(c=1.75, \mathrm{CHCl}_{3}\right) ;{ }^{1} \mathrm{H} \mathrm{NMR}\left(500 \mathrm{MHz}, \mathrm{CDCl}_{3}\right) \delta 9.53(\mathrm{~d}, J=8.0 \mathrm{~Hz}, 1 \mathrm{H})$, $7.37-7.30(\mathrm{~m}, 5 \mathrm{H}), 6.81(\mathrm{~d}, J=15.5 \mathrm{~Hz}, 1 \mathrm{H}), 6.08-6.03(\mathrm{~m}, 2 \mathrm{H}), 4.77(\mathrm{~s}, 2 \mathrm{H}), 4.59(\mathrm{~s}, 2 \mathrm{H})$, 3.77 (dd, $J=14,10.5 \mathrm{~Hz}, 2 \mathrm{H}), 3.68(\mathrm{dd}, J=12.5,10.5 \mathrm{~Hz}, 2 \mathrm{H}), 2.98(\mathrm{dd}, J=15,8.0 \mathrm{~Hz}$, $1 \mathrm{H}), 2.91(\mathrm{~d}, J=16.5 \mathrm{~Hz}, 1 \mathrm{H}), 2.81(\mathrm{dd}, J=15,7.5 \mathrm{~Hz}, 1 \mathrm{H}), 2.75(\mathrm{~d}, J=16 \mathrm{~Hz}, 1 \mathrm{H}), 1.16$ (s, 6H), 1.12-1.04 (m, 21H); ${ }^{13} \mathrm{C}$ NMR $\left(125 \mathrm{MHz}, \mathrm{CDCl}_{3}\right) \delta$ 194.5, 169.2, 166.7, 138.0, 137.8, 130.1, 128.7, 128.3, 128.1, 128.0, 95.2, 83.9, 70.0, 69.9, 66.0, 38.9, 38.5, 33.4, 26.4, 26.3, 18.1, 12.1; DEPT (125 MHz, $\mathrm{CDCl}_{3}$ ) $\mathrm{CH}_{3} \delta 26.4,26.3,18.1 ; \mathrm{CH}_{2} \delta 95.2,70.0,69.9$, 66.0, 38.9, 33.4; CH $\delta 194.5,166.7,138.0,130.1,128.7,128.3,128.1,12.1$; C $\delta 169.2$, 137.8, 128.0, 83.9, 38.2; IR (neat) 2944, 2867, 1757, 1693, 1464, 1369, 1117, 1047, 883, 803, $739 \mathrm{~cm}^{-1}$; HRMS (ESI) calcd 567.3118 for $\mathrm{C}_{31} \mathrm{H}_{48} \mathrm{O}_{6} \mathrm{NaSi}(\mathrm{M}+\mathrm{Na})$, found 567.3116

Bispyran (40).-To a stirring solution of hydroxyallylsilane 3 (66 mg, $0.092 \mathrm{mmol}, 1.0$ equiv) and aldehyde 29 (60 mg, $0.11 \mathrm{mmol}, 1.2$ equiv) in $\mathrm{Et}_{2} \mathrm{O}(2.3 \mathrm{~mL}, 0.04 \mathrm{M})$ contained in a $10 \mathrm{~mL}$ flask under $\mathrm{N}_{2}$ at $-78{ }^{\circ} \mathrm{C}$ was added a solution of TMSOTf in $\mathrm{Et}_{2} \mathrm{O}(1.0 \mathrm{M}, 120$ $\mu \mathrm{L}, 0.12 \mathrm{mmol}, 1.3$ equiv). The reaction mixture was stirred at $-78^{\circ} \mathrm{C}$ for $3 \mathrm{~h}$ and then quenched with $i$ - $\operatorname{Pr}_{2} \mathrm{NEt}(500 \mu \mathrm{L})$. After being stirred for $5 \mathrm{~min}$ at $-78{ }^{\circ} \mathrm{C}$, the solution was added to saturated aqueous $\mathrm{NaHCO}_{3}$ solution $(25 \mathrm{~mL})$. The mixture was extracted with EtOAc $(3 \times 10 \mathrm{~mL})$, dried over $\mathrm{Na}_{2} \mathrm{SO}_{4}$, filtered, and concentrated. The product was purified using a $2 \times 10 \mathrm{~cm}$ silica column, eluting with $10 \%$ EtOAc/hexanes, collecting $5 \mathrm{~mL}$ fractions. The product containing fractions, $8-22$, were combined and concentrated to yield the product $(90 \mathrm{mg}, 83 \%)$ as a colorless oil: $\mathrm{R}_{\mathrm{f}}=0.83\left(50 \%\right.$ EtOAc/hexanes); $[a]_{\mathrm{D}}{ }^{20}=$ $+1.56\left(c=3.4, \mathrm{CHCl}_{3}\right) ;{ }^{1} \mathrm{H} \mathrm{NMR}\left(500 \mathrm{MHz}, \mathrm{CDCl}_{3}\right) \delta 7.71-7.68(\mathrm{~m}, 4 \mathrm{H}), 7.45-7.35(\mathrm{~m}$, 
$10 \mathrm{H}), 7.32-7.29(\mathrm{~m}, 1 \mathrm{H}), 7.20(\mathrm{~d}, J=8.5 \mathrm{~Hz}, 2 \mathrm{H}), 6.86(\mathrm{~d}, J=8.0 \mathrm{~Hz}, 2 \mathrm{H}), 6.12$ (t, $J=7.5$ $\mathrm{Hz}, 1 \mathrm{H}), 5.63(\mathrm{~d}, J=16 \mathrm{~Hz}, 1 \mathrm{H}), 5.45(\mathrm{dd}, J=15.5,5.5 \mathrm{~Hz}, 1 \mathrm{H}), 4.78(\mathrm{~s}, 2 \mathrm{H}), 4.73(\mathrm{~d}, J=$ $11.5 \mathrm{~Hz}, 2 \mathrm{H}), 4.66(\mathrm{~s}, 1 \mathrm{H}), 4.61(\mathrm{~s}, 2 \mathrm{H}), 4.55(\mathrm{~s}, 1 \mathrm{H}), 4.43(\mathrm{ABq}, J=10.5 \mathrm{~Hz}, \Delta \mathrm{v}=35.1 \mathrm{~Hz}$, 2H), 3.98-3.93 (m, 1H), 3.85-3.83 (m, 1H), $3.80(\mathrm{~s}, 3 \mathrm{H}), 3.78(\mathrm{ABq}, J=10 \mathrm{~Hz}, \Delta \mathrm{v}=20.2$ $\mathrm{Hz}, 2 \mathrm{H}), 3.76-3.73(\mathrm{~m}, 1 \mathrm{H}), 3.69(\mathrm{~s}, 2 \mathrm{H}), 3.64-3.61(\mathrm{~m}, 1 \mathrm{H}), 3.59-3.55(\mathrm{~m}, 1 \mathrm{H}), 3.51-3.45$ $(\mathrm{m}, 1 \mathrm{H}), 2.90(\mathrm{~d}, J=16 \mathrm{~Hz}, 1 \mathrm{H}), 2.83-2.64(\mathrm{~m}, 3 \mathrm{H}), 2.30(\mathrm{~d}, J=23.5 \mathrm{~Hz}, 1 \mathrm{H}), 2.27(\mathrm{~d}, J=$ $24 \mathrm{~Hz}, 1 \mathrm{H}), 2.18(\mathrm{t}, J=15.5 \mathrm{~Hz}, 2 \mathrm{H}), 2.07-2.01(\mathrm{~m}, 3 \mathrm{H}), 1.98-1.91(\mathrm{~m}, 2 \mathrm{H}), 1.85-1.73(\mathrm{~m}$, $2 \mathrm{H}), 1.70-1.61(\mathrm{~m}, 4 \mathrm{H}), 1.08-1.03(\mathrm{~m}, 36 \mathrm{H}) ;{ }^{13} \mathrm{C} \mathrm{NMR}\left(125 \mathrm{MHz}, \mathrm{CDCl}_{3}\right) \delta 169.3,159.3$, 145.0, 144.3, 140.7, 140.6, 137.8, 135.8, 134.1, 134.0, 131.2, 129.8, 129.6, 128.6, 128.1, 128.06, 128.01, 127.85, 127.84 126.8, 114.0, 109.0, 108.7, 95.2, 83.5, 79.2, 75.1, 75.0, 74.8, 72.8, 72.3, 70.0, 69.8, 66.0, 60.6, 55.5, 43.1, 42.6, 41.5, 41.4, 41.2, 40.4, 39.8, 38.0, 36.6, 33.5, 27.2, 27.1, 27.0, 19.4, 18.1, 12.1; DEPT (125 MHz, $\left.\mathrm{CDCl}_{3}\right) \mathrm{CH}_{3}$ \& 55.5, 27.2, 18.1; $\mathrm{CH}_{2} \delta 109.1,108.7,95.2,72.3,70.0,69.8,66.0,60.6,43.1,42.6,41.5,41.4,41.3,40.4$, $39.8,38.1,33.5$; CH $\delta 140.7,140.6,135.8,129.8,129.6,128.7,128.1,128.0,128.0,127.9$, 114.0, 79.2, 75.1, 75.0, 74.8, 72.8, 12.1; C $\delta 169.3,159.3,145.0,144.3,137.8,134.1,134.0$, 131.2, 83.5, 36.6, 19.4; IR (neat) 3072, 2941, 1761, 1613, 1514, 1464, 1428, 1362, 1248, $1110,846,730,703 \mathrm{~cm}^{-1}$; HRMS (ESI) calcd 1191.6753 for $\mathrm{C}_{71} \mathrm{H}_{100} \mathrm{O}_{10} \mathrm{NaSi}_{2}(\mathrm{M}+\mathrm{Na})$, found 1191.6760 .

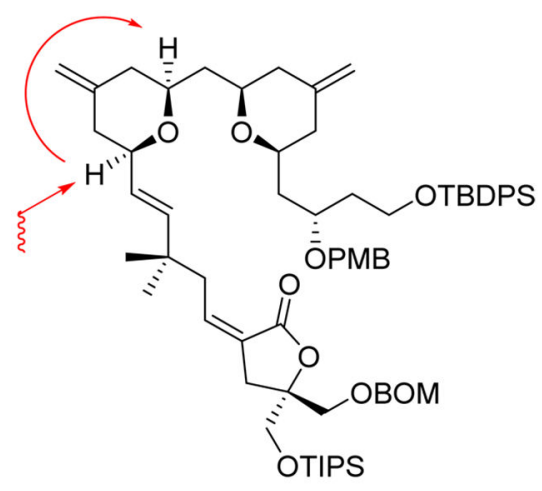

Key 1D ROESY Correlations

C1 Alcohol (41).-To a stirring solution of ester 40 (59 mg, $0.05 \mathrm{mmol}, 1.0$ equiv) in THF $(1.0 \mathrm{~mL}, 0.05 \mathrm{M})$ contained in a $10 \mathrm{~mL}$ polyethylene vial at $0{ }^{\circ} \mathrm{C}$ was added a solution of $20 \%$ HF.Pyr in pyridine $(1.25 \mathrm{~mL}, 25 \mathrm{~mL} / \mathrm{mmol})$. The solution was stirred at $0{ }^{\circ} \mathrm{C}$ for $5 \mathrm{~h}$, after which it was quenched by slowly pipetting it into stirring, saturated aqueous $\mathrm{NaHCO}_{3}$ solution $(30 \mathrm{~mL})$. The mixture was extracted with EtOAc $(3 \times 10 \mathrm{~mL})$, dried over $\mathrm{Na}_{2} \mathrm{SO}_{4}$, filtered, and concentrated. The crude alcohol was purified using a $2 \times 10 \mathrm{~cm}$ silica gel column, eluting with $30 \%$ EtOAc/hexanes, collecting $5 \mathrm{~mL}$ fractions. Concentration of fractions $10-36$ yielded the product $(32 \mathrm{mg}, 68 \%)$ as a colorless oil: $\mathrm{R}_{\mathrm{f}}=0.48(50 \% \mathrm{EtOAc} /$ hexanes); $[a]_{\mathrm{D}}{ }^{20}=-0.88\left(c=0.57, \mathrm{CHCl}_{3}\right) ;{ }^{1} \mathrm{H} \mathrm{NMR}\left(500 \mathrm{MHz}, \mathrm{CDCl}_{3}\right) \delta 7.37-7.28(\mathrm{~m}$, $5 \mathrm{H}), 7.26(\mathrm{~d}, J=8.5 \mathrm{~Hz}, 2 \mathrm{H}), 6.89(\mathrm{~d}, J=8.5 \mathrm{~Hz}, 2 \mathrm{H}), 6.12(\mathrm{t}, J=8.0 \mathrm{~Hz}, 1 \mathrm{H}), 5.66(\mathrm{~d}, J=$ $16.5 \mathrm{~Hz}, 1 \mathrm{H}), 5.45(\mathrm{dd}, J=15.5,5.5 \mathrm{~Hz}, 1 \mathrm{H}), 4.77(\mathrm{~s}, 2 \mathrm{H}), 4.74(\mathrm{~m}, 2 \mathrm{H}), 4.69(\mathrm{~s}, 1 \mathrm{H}), 4.60$ $(\mathrm{s}, 2 \mathrm{H}), 4.60(\mathrm{~s}, 1 \mathrm{H}), 4.48(\mathrm{q}, J=10 \mathrm{~Hz}, 2 \mathrm{H}), 4.02-3.97(\mathrm{~m}, 1 \mathrm{H}), 3.85-3.80(\mathrm{~m}, 1 \mathrm{H}), 3.80(\mathrm{~s}$, $3 \mathrm{H}), 3.76-3.73(\mathrm{~m}, 1 \mathrm{H}), 3.77(\mathrm{ABq}, J=10.5 \mathrm{~Hz}, \Delta \mathrm{v}=20.9 \mathrm{~Hz}, 2 \mathrm{H}), 3.68(\mathrm{~s}, 2 \mathrm{H}), 3.58-3.53$ (m, 1H), 3.52-3.43 (m, 2H), $2.90(\mathrm{~d}, J=17 \mathrm{~Hz}, 1 \mathrm{H}), 2.80(\mathrm{dd}, J=16,8.0 \mathrm{~Hz}, 1 \mathrm{H}), 2.73(\mathrm{~d}, J$ 
$=19 \mathrm{~Hz}, 1 \mathrm{H}), 2.69(\mathrm{dd}, J=15.5,7.5 \mathrm{~Hz}, 1 \mathrm{H}), 2.36(\mathrm{~s}, 1 \mathrm{H}), 2.29-2.18(\mathrm{~m}, 4 \mathrm{H}), 2.06-1.92$ (m, 6H), 1.80 (dddd, $J=14.5,9.0,8.5,2.5 \mathrm{~Hz}, 1 \mathrm{H}), 1.75-1.62(\mathrm{~m}, 4 \mathrm{H}), 1.10-1.03(\mathrm{~m}, 27 \mathrm{H})$; ${ }^{13} \mathrm{C}$ NMR $\left(125 \mathrm{MHz}, \mathrm{CDCl}_{3}\right) \delta 169.3,159.6,144.7,144.4,140.7,140.6,137.9,130.7$, 129.7, 129.6, 128.7, 128.1, 128.0, 126.7, 114.2, 109.0, 108.9, 95.2, 83.6, 79.4, 77.4, 75.5, 75.3, 75.1, 72.1, 70.1, 69.8, 66.0, 60.5, 55.5, 43.0, 41.8, 41.5, 41.1, 40.5, 39.8, 36.9, 36.6, 33.6, 27.1, 27.1, 18.1, 12.1; DEPT (125 MHz, $\left.\mathrm{CDCl}_{3}\right) \mathrm{CH}_{3} \delta 55.5,27.1,27.0,18.1 ; \mathrm{CH}_{2} \delta$ 109.0, 108.9, 95.2, 72.1, 70.0, 69.8, 66.0, 60.5, 43.0, 41.8, 41.5, 41.1, 40.5, 39.8, 36.8, 33.5; CH $\delta 140.7,140.6,129.7,129.6,128.6,128.1,114.1,79.4,77.4,75.5,75.2,75.2,12.1$; C $\delta$ 169.3, 159.6, 144.7, 144.4, 137.9, 130.7, 126.7, 83.6, 36.6; IR (neat) 3488, 2942, 1758, 1652, 1612, 1514, 1464, 1366, 1248, 1048, 884, 804, 739, $684 \mathrm{~cm}^{-1}$; HRMS (ESI) calcd 953.5575 for $\mathrm{C}_{55} \mathrm{H}_{82} \mathrm{O}_{10} \mathrm{NaSi}(\mathrm{M}+\mathrm{Na})$, found 953.5592 .

C1 Acid (42).-To a stirring solution of alcohol 41 (37 mg, $0.04 \mathrm{mmol}, 1.0$ equiv) in $\mathrm{CH}_{2} \mathrm{Cl}_{2}(800 \mu \mathrm{L}, 0.05 \mathrm{M})$ contained in a $5 \mathrm{~mL}$ vial under $\mathrm{N}_{2}$ was added $i-\operatorname{Pr}_{2} \mathrm{NEt}(70 \mu \mathrm{L}$, $0.40 \mathrm{mmol}, 10.0$ equiv), followed by DMSO ( $20 \mu \mathrm{L}, 0.28 \mathrm{mmol}, 7.0$ equiv). The mixture was cooled to $0{ }^{\circ} \mathrm{C}$, and $\mathrm{SO}_{3}-\mathrm{Pyr}(26 \mathrm{mg}, 0.16 \mathrm{mmol}, 4.0$ equiv) was added. After being stirred at $0{ }^{\circ} \mathrm{C}$ for $1 \mathrm{~h}$, the reaction mixture was quenched with saturated aqueous $\mathrm{NaHCO}_{3}$ solution $(25 \mathrm{~mL})$ and extracted with $\mathrm{CH}_{2} \mathrm{Cl}_{2}(3 \times 10 \mathrm{~mL})$. The organic phase was then dried over $\mathrm{Na}_{2} \mathrm{SO}_{4}$, filtered, and concentrated. The product was purified on a $1 \times 10 \mathrm{~cm}$ silica gel column, eluting with $20 \%$ EtOAc/hexanes, collecting $5 \mathrm{~mL}$ fractions. Fractions 6-14 were concentrated to yield the intermediate aldehyde as a colorless oil which was used without further characterization $(28 \mathrm{mg}, 75 \%)$.

To a stirring solution of the aforementioned aldehyde (28 mg, $0.030 \mathrm{mmol}, 1.0$ equiv) in $t$ $\mathrm{BuOH}(430 \mu \mathrm{L}, 14.3 \mathrm{~mL} / \mathrm{mmol})$ and 2-methyl-2-butene ( $430 \mu \mathrm{L}, 14.3 \mathrm{~mL} / \mathrm{mmol})$ contained in a $5 \mathrm{~mL}$ vial was added an aqueous solution of $\mathrm{KH}_{2} \mathrm{PO}_{4}(1.25 \mathrm{M}, 144 \mu \mathrm{L}, 0.18 \mathrm{mmol}, 6.0$ equiv). The rapidly stirred reaction mixture was cooled to $-5{ }^{\circ} \mathrm{C}$, and $80 \% \mathrm{NaClO}_{2}(17 \mathrm{mg}$, $0.15 \mathrm{mmol}, 5.0$ equiv) was added. The reaction mixture was stirred at $0{ }^{\circ} \mathrm{C}$ for $1.5 \mathrm{~h}$ and then quenched with aqueous $\mathrm{pH} 4.0$ acetate buffer $(0.1 \mathrm{M}, 25 \mathrm{~mL})$. After extraction with EtOAc $(3 \times 10 \mathrm{~mL})$, the solution was dried over $\mathrm{Na}_{2} \mathrm{SO}_{4}$, filtered, and concentrated. The resulting product was purified using a $2 \times 15 \mathrm{~cm}$ silica gel column, eluting with $40 \%$ EtOAc/hexanes, collecting $5 \mathrm{~mL}$ fractions. Fractions $8-28$ were combined and concentrated to yield the product as a colorless oil $(15 \mathrm{mg}, 54 \%): \mathrm{R}_{\mathrm{f}}=0.48\left(20 / 5 / 0.3 \mathrm{PhCH}_{3} / \mathrm{EtOAc} / \mathrm{AcOH}\right) ;[a]_{\mathrm{D}}{ }^{20}$ $=+9.4\left(c=0.74, \mathrm{CHCl}_{3}\right) ; 500 \mathrm{MHz}{ }^{1} \mathrm{H}$ NMR $\left(\mathrm{C}_{6} \mathrm{D}_{6}\right) \delta 7.29(\mathrm{dd}, J=7.5,3.0 \mathrm{~Hz}, 4 \mathrm{H}), 7.16$ (t, $J=7.0 \mathrm{~Hz}, 2 \mathrm{H}), 7.07$ (t, $J=10 \mathrm{~Hz}, 1 \mathrm{H}), 6.81(\mathrm{~d}, J=8.5 \mathrm{~Hz}, 2 \mathrm{H}), 6.00(\mathrm{t}, J=8.0 \mathrm{~Hz}, 1 \mathrm{H})$, $5.69(\mathrm{~d}, J=16 \mathrm{~Hz}, 1 \mathrm{H}), 5.55(\mathrm{dd}, J=16.5,6.0 \mathrm{~Hz}, 1 \mathrm{H}), 4.74(\mathrm{~s}, 2 \mathrm{H}), 4.65(\mathrm{~d}, J=4.0 \mathrm{~Hz}$, $2 \mathrm{H}), 4.55(\mathrm{~s}, 2 \mathrm{H}), 4.51(\mathrm{ABq}, J=11 \mathrm{~Hz}, \Delta \mathrm{v}=54.2 \mathrm{~Hz}, 2 \mathrm{H}), 4.48(\mathrm{~s}, 2 \mathrm{H}), 3.81(\mathrm{dd}, J=10$, $5.5 \mathrm{~Hz}, 1 \mathrm{H}), 3.69-3.62(\mathrm{~m}, 2 \mathrm{H}), 3.67(\mathrm{~d}, J=3.0 \mathrm{~Hz}, 2 \mathrm{H}), 3.54-3.47(\mathrm{~m}, 2 \mathrm{H}), 3.51$ (d, $J=5.5$ $\mathrm{Hz}, 2 \mathrm{H}), 3.31(\mathrm{~s}, 3 \mathrm{H}), 3.02(\mathrm{dd}, J=14.5,7.5 \mathrm{~Hz}, 1 \mathrm{H}), 2.86$ (dd, $J=14.5,7.0 \mathrm{~Hz}, 1 \mathrm{H}), 2.69$ (dd, $J=16.5,2.0 \mathrm{~Hz}, 1 \mathrm{H}), 2.50-2.42(\mathrm{~m}, 3 \mathrm{H}), 2.18(\mathrm{t}, J=14 \mathrm{~Hz}, 2 \mathrm{H}), 2.12-2.03(\mathrm{~m}, 3 \mathrm{H})$, $1.97-1.76(\mathrm{~m}, 5 \mathrm{H}), 1.66-1.54(\mathrm{~m}, 2 \mathrm{H}), 1.04-1.00(\mathrm{~m}, 27 \mathrm{H}) ;{ }^{13} \mathrm{C} \mathrm{NMR}\left(125 \mathrm{MHz}, \mathrm{CDCl}_{3}\right) \delta$ $174.5,169.3,159.6,144.5,144.3,140.8,140.7,137.8,130.3,129.7,128.7,128.1,128.0$, 128.0, 126.7, 114.2, 109.1, 109.0, 95.2, 83.6, 79.3, 75.3, 75.2, 75.0, 72.9, 72.4, 70.1, 69.8, 66.0, 55.5, 43.0, 42.0, 41.4, 41.3, 41.0, 40.6, 40.0, 39.8, 36.7, 33.6, 27.1, 27.1, 18.1, 12.1; DEPT (125 MHz, $\left.\mathrm{CDCl}_{3}\right) \mathrm{CH}_{3} \delta 55.5,27.1,27.0,18.1 ; \mathrm{CH}_{2} \delta 109.1,109.0,95.2,72.4$, 
70.0, 69.8, 66.0, 43.0, 41.9, 41.4, 41.3, 41.0, 40.6, 40.0, 39.8, 33.5; CH $\delta 140.7,140.6$, $129.7,128.6,128.1,128.0,128.0,114.1,79.3,75.2,75.2,75.0,72.9,12.1$; C $\delta 174.5,169.3$, $159.6,144.5,144.3,137.8,130.3,126.7,83.6,36.7$; IR (neat) 2943, 2867, 1758, 1712, 1653, 1613, 1514, 1464, 1367, 1249, 1172, 1112, 1046, 884, 805, $739 \mathrm{~cm}^{-1}$; HRMS (ESI) calcd 967.5368 for $\mathrm{C}_{55} \mathrm{H}_{80} \mathrm{O}_{11} \mathrm{NaSi}(\mathrm{M}+\mathrm{Na})$, found 967.5378 .

Macrolactone (43).- To a stirring solution of acid $42(0.037 \mathrm{mmol}, 1.0$ equiv) in THF $(740 \mu \mathrm{L}, 0.05 \mathrm{M})$ contained in a $10 \mathrm{~mL}$ polyethylene vial at $\mathrm{rt}$ was added a $20 \%$ solution of HF.Pyr in pyridine ( $925 \mu \mathrm{L}, 25 \mathrm{mmol} / \mathrm{mL})$. The mixture was stirred at $\mathrm{rt}$ for 2 days, then quenched by pouring into aqueous $\mathrm{pH} 4.0$ acetate buffer $(0.1 \mathrm{M}, 25 \mathrm{~mL})$. The mixture was extracted with EtOAc $(3 \times 10 \mathrm{~mL})$, dried over $\mathrm{Na}_{2} \mathrm{SO}_{4}$, filtered, and concentrated. The product was purified on a $1 \times 10 \mathrm{~cm}$ silica gel column, eluting with $3 \% \mathrm{MeOH} / \mathrm{CH}_{2} \mathrm{Cl}_{2}$, collecting $5 \mathrm{~mL}$ fractions. Fractions $4-16$ were concentrated to yield the product as a colorless oil which was used without characterization for the subsequent macrolactonization.

To a stirring solution of the aforementioned seco-acid in THF $(1.2 \mathrm{~mL}, 0.03 \mathrm{M})$ contained in a $10 \mathrm{~mL}$ flask under $\mathrm{N}_{2}$ was added a solution of $\mathrm{Et}_{3} \mathrm{~N}$ in $\mathrm{THF}(1.0 \mathrm{M}, 220 \mu \mathrm{L}, 0.22 \mathrm{mmol}$, 6.0 equiv). The reaction mixture was cooled to $0{ }^{\circ} \mathrm{C}$, and a solution of 2,4,6-trichlorobenzoyl chloride in THF (1.0 M, $110 \mu \mathrm{L}, 0.11 \mathrm{mmol}, 3.0$ equiv) was added. The reaction mixture was stirred at $0{ }^{\circ} \mathrm{C}$ for $5 \mathrm{~min}$ and warmed to $\mathrm{rt}$. The reaction mixture was then stirred at $\mathrm{rt}$ for $3 \mathrm{~h}$. The resulting solution was taken up into $\mathrm{PhCH}_{3}(10 \mathrm{~mL})$ in a $25 \mathrm{~mL}$ gastight syringe and added over $16 \mathrm{~h}$ via syringe pump to a stirring solution of DMAP (90 mg, $0.74 \mathrm{mmol}$, 20.0 equiv) in $\mathrm{PhCH}_{3}(27 \mathrm{~mL})$ contained in a $100 \mathrm{~mL}$ flask under $\mathrm{N}_{2}$ at $40{ }^{\circ} \mathrm{C}$, achieving a final concentration of $0.001 \mathrm{M}$ in substrate. After $16 \mathrm{~h}, \mathrm{PhCH}_{3}(1.0 \mathrm{~mL})$ was used to complete the transfer of the reactant. The reaction mixture was stirred for an additional $\mathrm{h}$ at $40{ }^{\circ} \mathrm{C}$, then cooled to $\mathrm{rt}$, quenched with brine $(50 \mathrm{~mL})$, and extracted with EtOAc $(3 \times 10$ $\mathrm{mL}$ ). After being dried over $\mathrm{Na}_{2} \mathrm{SO}_{4}$, the solution was filtered and concentrated. The product was purified using a $1 \times 12 \mathrm{~cm}$ silica gel column, eluting with $15 \%$ EtOAc/hexanes, collecting $5 \mathrm{~mL}$ fractions. Fractions 12-24 were combined and concentrated to yield the product as a colorless oil $(11 \mathrm{mg}, 38 \%): R_{f}=0.25(25 \%$ EtOAc/hexanes $) ;[a]_{\mathrm{D}}{ }^{20}=+22.4(c$ $\left.=0.42, \mathrm{CHCl}_{3}\right) ;{ }^{1} \mathrm{H} \mathrm{NMR}\left(500 \mathrm{MHz}, \mathrm{CDCl}_{3}\right) \delta 7.36-7.28(\mathrm{~m}, 5 \mathrm{H}), 7.24(\mathrm{~d}, J=8.5 \mathrm{~Hz}, 2 \mathrm{H})$, $6.89(\mathrm{~d}, J=9.0 \mathrm{~Hz}, 2 \mathrm{H}), 6.17(\mathrm{t}, J=8.5 \mathrm{~Hz}, 1 \mathrm{H}), 5.59$ (d, $J=17 \mathrm{~Hz}, 1 \mathrm{H}), 5.40$ (dd, $J=16$, $4.0 \mathrm{~Hz}, 1 \mathrm{H}), 4.90(\mathrm{~d}, J=6.5 \mathrm{~Hz}, 1 \mathrm{H}), 4.78(\mathrm{~d}, J=6.5 \mathrm{~Hz}, 1 \mathrm{H}), 4.72-4.70(\mathrm{~m}, 3 \mathrm{H}), 4.65$ (s, $1 \mathrm{H}), 4.62(\mathrm{ABq}, J=12 \mathrm{~Hz}, \Delta \mathrm{v}=35.9 \mathrm{~Hz}, 2 \mathrm{H}), 4.53(\mathrm{~m}, 1 \mathrm{H}), 4.46(\mathrm{ABq}, J=11 \mathrm{~Hz}, \Delta \mathrm{v}=$ $38.5 \mathrm{~Hz}, 2 \mathrm{H}), 4.09(\mathrm{~m}, 1 \mathrm{H}), 4.01$ (d, $J=11.5 \mathrm{~Hz}, 1 \mathrm{H}), 3.81(\mathrm{~s}, 3 \mathrm{H}), 3.73-3.71(\mathrm{~m}, 1 \mathrm{H}), 3.69$ $(\mathrm{q}, J=10.5 \mathrm{~Hz}, 2 \mathrm{H}), 3.50-3.41(\mathrm{~m}, 2 \mathrm{H}), 3.36-3.32(\mathrm{~m}, 1 \mathrm{H}), 2.81-2.74(\mathrm{~m}, 3 \mathrm{H}), 2.62-2.54$ $(\mathrm{m}, 3 \mathrm{H}), 2.26(\mathrm{~d}, J=13.5 \mathrm{~Hz}, 2 \mathrm{H}), 2.21(\mathrm{~d}, J=13.5 \mathrm{~Hz}, 1 \mathrm{H}), 2.15(\mathrm{~d}, J=13.5 \mathrm{~Hz}, 1 \mathrm{H})$, 2.01-1.89 (m, 5H), 1.79-1.69 (m, 2H), 1.60-1.54(m, 1H), $1.11(\mathrm{~s}, 3 \mathrm{H}), 1.06(\mathrm{~s}, 3 \mathrm{H}) ;{ }^{13} \mathrm{C}$ NMR (125 MHz, $\left.\mathrm{CDCl}_{3}\right) \delta 170.7,168.6,159.5,144.6,144.5,141.4,137.8,137.8,130.5$, 129.5,129.0,128.7,128.0,128.0,125.8,114.1,109.0,108.9,94.9,81.4, 78.5, 77.4, 75.5, 75.4, 73.5, 71.8, 69.9, 65.1, 55.5, 43.7, 42.3, 41.3, 41.3, 41.2, 41.0, 40.3, 37.9, 34.8, 22.6, 14.3; DEPT (125 MHz, $\left.\mathrm{CDCl}_{3}\right) \mathrm{CH}_{3} \delta 55.5,14.3 ; \mathrm{CH}_{2} \delta 109.0,108.9,94.9,71.8,69.9,65.1$, 43.6, 42.3, 41.3, 41.3, 41.2, 41.0, 34.8, 22.5; CH $\delta 141.4$, 137.8, 129.5, 129.0, 128.7, 128.1, $128.0,114.1,78.5,77.5,75.5,75.4,73.5$; C $\delta 170.7,168.6,159.5,144.6,144.5,137.8$, 130.5, 125.8, 81.4, 37.9; IR (neat) 3057, 2916, 1762, 1744, 1707, 1675, 1632, 1576, 1562, 
1496, 1446, 1343, 1220, 1077, 1007, 946, 867, 809, $698 \mathrm{~cm}^{-1}$; HRMS (ESI) calcd 793.3928 for $\mathrm{C}_{46} \mathrm{H}_{58} \mathrm{O}_{10} \mathrm{Na}(\mathrm{M}+\mathrm{Na})$, found 793.3939.

Merle 48.-To a stirring solution of macrolactone 43 ( $9.0 \mathrm{mg}, 0.012 \mathrm{mmol}, 1.0$ equiv) in $\mathrm{CH}_{2} \mathrm{Cl}_{2}(1.2 \mathrm{~mL}, 0.01 \mathrm{M})$ contained in a $5 \mathrm{~mL}$ vial was added $\mathrm{H}_{2} \mathrm{O}(30 \mu \mathrm{L})$. After being cooled to $0{ }^{\circ} \mathrm{C}$, DDQ $(27 \mathrm{mg}, 0.12 \mathrm{mmol}, 10.0$ equiv) was added and the reaction mixture was stirred at $0{ }^{\circ} \mathrm{C}$ for $1 \mathrm{~h}$. The reaction mixture was quenched with saturated aqueous $\mathrm{NaHCO}_{3}$ solution $(10 \mathrm{~mL})$, then extracted with $\mathrm{CH}_{2} \mathrm{Cl}_{2}(3 \times 5 \mathrm{~mL})$, dried over $\mathrm{Na}_{2} \mathrm{SO}_{4}$, filtered, and concentrated. The crude alcohol was used without purification for the subsequent reaction.

To the previously prepared alcohol contained in a $5 \mathrm{~mL}$ vial, a solution of $\mathrm{LiBF}_{4}$ in $25: 1$ $\mathrm{MeCN} / \mathrm{H}_{2} \mathrm{O}(0.25 \mathrm{M}, 2.0 \mathrm{~mL}, 45.0$ equiv $)$ was added. The vial was flushed with $\mathrm{N}_{2}$, capped, and heated at $80^{\circ} \mathrm{C}$ overnight. After being cooled to rt, the reaction mixture was concentrated to dryness and taken up in EtOAc $(10 \mathrm{~mL})$. The solution was partitioned with brine $(25 \mathrm{~mL})$ and subsequently extracted with EtOAc $(2 \times 10 \mathrm{~mL})$. The combined organic phases were dried over $\mathrm{Na}_{2} \mathrm{SO}_{4}$, filtered, and concentrated. The crude product was purified using a $1 \times 11 \mathrm{~cm}$ silica gel column, eluting with $35 \%$ EtOAc/pentane, collecting $5 \mathrm{~mL}$ fractions. Fractions 20-48 were combined and concentrated to yield the macrolide as a colorless oil (3.8 mg, 59\% over 2 steps): $R_{f}=0.36$ (50\% EtOAc/hexanes); $[a]_{\mathrm{D}}{ }^{20}=-27(c=$ $\left.0.12, \mathrm{CHCl}_{3}\right) ;{ }^{1} \mathrm{H}$ NMR $\left(500 \mathrm{MHz}, \mathrm{CDCl}_{3}\right) \delta 6.24(\mathrm{t}, J=8.5 \mathrm{~Hz}, 1 \mathrm{H}), 5.58(\mathrm{~d}, J=16 \mathrm{~Hz}$, $1 \mathrm{H}), 5.34(\mathrm{dd}, J=16,5.5 \mathrm{~Hz}, 1 \mathrm{H}), 4.78(\mathrm{~s}, 2 \mathrm{H}), 4.75(\mathrm{~s}, 2 \mathrm{H}), 4.56(\mathrm{~d}, J=11.5 \mathrm{~Hz}, 1 \mathrm{H}), 4.34$ (m, $1 \mathrm{H}), 4.00(\mathrm{~d}, J=12 \mathrm{~Hz}, 1 \mathrm{H}), 3.70-3.63(\mathrm{~m}, 4 \mathrm{H}), 3.45-3.31(\mathrm{~m}, 4 \mathrm{H}), 2.88(\mathrm{~d}, J=15 \mathrm{~Hz}$, $1 \mathrm{H}), 2.82(\mathrm{dd}, J=14,4.5 \mathrm{~Hz}, 1 \mathrm{H}), 2.59(\mathrm{~d}, J=16 \mathrm{~Hz}, 1 \mathrm{H}), 2.45(\mathrm{dd}, J=9.5,4.0 \mathrm{~Hz}, 1 \mathrm{H})$, 2.34 (d, $J=13 \mathrm{~Hz}, 1 \mathrm{H}), 2.20-2.14(\mathrm{~m}, 5 \mathrm{H}), 2.03-1.95(\mathrm{~m}, 4 \mathrm{H}), 1.90$ (t, $J=11.5 \mathrm{~Hz}, 1 \mathrm{H})$, $1.77(\mathrm{t}, J=14.5 \mathrm{~Hz}, 1 \mathrm{H}), 1.64-1.59(\mathrm{~m}, 2 \mathrm{H}), 1.12$ (s, 3H), 1.10 (s, 3H); ${ }^{13} \mathrm{C}$ NMR $(125$ $\left.\mathrm{MHz}, \mathrm{CDCl}_{3}\right) \delta 170.1,169.0,143.8,143.6,141.7,139.4,128.3,126.1,109.6,109.4,82.7$, 79.8, 76.1, 75.3, 75.1, 66.0, 65.7, 62.0, 44.6, 43.8, 42.7, 41.8, 41.6, 41.3, 41.3, 40.3, 38.2, 34.6, 30.3, 25.1; DEPT (125 MHz, $\left.\mathrm{CDCl}_{3}\right) \mathrm{CH}_{3} \delta 30.3,25.1 ; \mathrm{CH}_{2} \delta$ 109.6, 109.4, 66.0, 62.0, 44.6, 43.8, 42.7, 41.8, 41.6, 41.3, 41.3, 40.3, 34.6; CH $\delta 141.7,139.4,128.3,79.8$, 76.1, 75.3, 75.1, 65.7; C $\delta 170.1,169.0,143.8,143.6,126.1,82.7,38.2$; IR (neat) 3444, 2940, 1743, 1671, 1653, 1559, 1541, 1437, 1366, 1327, 1281, 1246, 1219, 1161, 1123, 1098, 1072, 1042, 1000, 981, 936, 893, $792 \mathrm{~cm}^{-1}$ HRMS (ESI) calcd 553.2777 for $\mathrm{C}_{30} \mathrm{H}_{42} \mathrm{O}_{8} \mathrm{Na}(\mathrm{M}+\mathrm{Na})$, found 553.2778.

\section{Molecular Modeling.}

Conformational Searching.-The initial structures for Merle 46, Merle 47, and Merle 48 were built based on the crystal structure of bryostatin $1^{55}$ from the Cambridge Structural Database (reference code BOKKIV) to keep the structure of the (A + B)-rings consistent. All searches were performed using mixed torsional/large-scale low-mode sampling in MacroModel ${ }^{56-58}$ with the OPLS 2005 force field ${ }^{59}$ in octanol implicit solvent. During the searches torsions were varied for 10,000 steps with enhanced sampling, but the chiral centers and double bonds were restricted to their crystal conformations. Low mode displacements were between 3 and $18 \AA$. After each step the resulting structure was energy-minimized to a gradient convergence of 0.05 . The minimized structure was then compared to previously 
stored structures and either kept as a unique conformer or rejected as a duplicate, using a $0.75 \AA$ rmsd cutoff to the heavy atoms in the central macrolide ring structure. A set of lowenergy conformers for each structure, with energies with $3 \mathrm{kcal} / \mathrm{mol}$ of the global minimum, were passed on to the docking program.

Docking.-The crystal structure of the $\mathrm{C} 1 \mathrm{~b}$ domain of $\mathrm{PKC} \delta^{60}$ was prepared for docking by adding hydrogen atoms and deleting the phorbol-13-acetate ligand. This was saved to a separate file to be used as a template for the similarity constraint (see below). Docking was done using the program GOLD, version 5.2.2, ${ }^{61}$ which uses a genetic algorithm to optimize the set of interactions between the ligand and the protein. Default settings were used for the genetic algorithm. The binding site was defined as a sphere with a $10.0 \AA$ radius, centered on the $\mathrm{N} \varepsilon$ atom of residue Gln 257. For each conformer, 20 docking runs were performed, with no early termination, using the GoldScore scoring function with an internal ligand energy offset. Free corners of ligand rings were allowed to flip above or below the plane of their neighboring atoms during docking, and intramolecular hydrogen bonds in the ligand were allowed to form. Torsion angle distributions were from the CSD. A template similarity constraint was added to bias the conformation of docked ligands toward solutions where the acceptor atoms in the ligand were close in space to the acceptor atoms in bound phorbol-13$O$-acetate from the crystal structure.

Energy Minimization.-A subset of diverse poses with fitness score $>40.0$ were further refined by energy minimization in MacroModel, ${ }^{57}$ using the OPLS_2005 force field and octanol implicit solvent. All atoms in the $\mathrm{C} 1$ domain were held fixed, while ligand atoms were free to move, and the complex was minimized using the Polak-Ribiere conjugate gradient scheme to a gradient convergence of 0.05 . Hydrogen bonds in the docked poses were preserved using distance constraints.

\section{Supplementary Material}

Refer to Web version on PubMed Central for supplementary material.

\section{ACKNOWLEDGMENTS}

Financial support was provided by the National Institutes of Health through Grant No. GM28961 and was supported in part by the Intramural Research Program of the National Institutes of Health, Center for Cancer Research, National Cancer Institute (Project Z1A BC 005270). The project was also funded in part with Federal funds from the National Cancer Institute, National Institutes of Health, under Contract HHSN261200800001E.

\section{REFERENCES}

(1). Pettit GR; Day JF; Hartwell JL; Wood HB Nature 1970, 227, 962. [PubMed: 4393654]

(2). Pettit GR; Herald CL; Hogan F In Anticancer Drug Development; Baguley BC, Kerr DJ, Eds.; Academic Press: San Diego, CA, 2002; pp 203-235.

(3). Hale KJ; Hummersone MG; Manaviazar S; Frigerio M Nat. Prod. Rep 2002, 19, 413-453. [PubMed: 12195811]

(4). Hale KJ; Manaviazar S Chem. - Asian J 2010, 5, 704-754. [PubMed: 20354984]

(5). Mehla R; Bivalkar-Mehla S; Zhang R; Handy I; Albrecht H; Giri S; Nagarkatti P; Nagarkatti M; Chauhan A PLoS One 2010, 5 (6) , e11160. [PubMed: 20585398] 
(6). Sun MK; Hongpaisan J; Nelson TJ; Alkon DL Proc. Natl. Acad. Sci. U. S. A 2008, 105 (36), 13620-13625. [PubMed: 18768786]

(7). Denvir J; Neitch S; Fan J; Niles RM; Boskovic G; Schreurs BG; Primerano DA; Alkon DL J. Alzheimer's Dis 2015, 46, 483-490. [PubMed: 25812849]

(8). Hofmann J Curr. Cancer Drug Targets 2004, 4, 125-146. [PubMed: 15032665]

(9). Battaini F Pharmacol. Res 2001, 44 (5), 353-361. [PubMed: 11712865]

(10). Colon-Gonzalez F; Kazanietz MG Biochim. Biophys. Acta, Mol. Cell Biol. Lipids 2006, 1761, 827-837.

(11). Hennings H; Boutwell RK Cancer Res. 1970, 30, 312-320. [PubMed: 5458969]

(12). Hennings H; Blumberg PM; Pettit GR; Herald CL; Shores R; Yuspa SH Carcinogenesis 1987, 8 (9), 1343-1346. [PubMed: 3621472]

(13). Kraft AS; Smith JB; Berkow RL Proc. Natl. Acad. Sci. U. S. A 1986, 83, 1334-1338. [PubMed: 3456591]

(14). Keck GE; Kraft MB; Truong AP; Li W; Sanchez CC; Kedei N; Lewin NE; Blumberg PM J. Am. Chem. Soc 2008, 130, 6660-6661. [PubMed: 18452293]

(15). Keck GE; Poudel YB; Welch DS; Kraft MB; Truong AP; Stephens JC; Kedei N; Lewin NE; Blumberg PM Org. Lett 2009, 11 (3), 593-596. [PubMed: 19113896]

(16). Andrews IP; Ketcham JM; Blumberg PM; Kedei N; Lewin NE; Krische MJ J. Am. Chem. Soc 2014, 136, 13209-13216. [PubMed: 25207655]

(17). Kedei N; Kraft MB; Keck GE; Herald CL; Melody N; Pettit GR; Blumberg PM J. Nat. Prod 2015, 78, 896-900. [PubMed: 25808573]

(18). Marquez VE; Blumberg PM Acc. Chem. Res 2003, 36, 434-443. [PubMed: 12809530]

(19). Keck GE; Li W; Kraft MB; Kedei N; Lewin NE; Blumberg PM Org. Lett. 2009, 11 (11), 22772280. [PubMed: 19419164]

(20). Keck GE; Poudel YB; Rudra A; Stephens JC; Kedei N; Lewin NE; Peach ML; Blumberg PM Angew. Chem., Int. Ed 2010, 49 (27), 4580-4584.

(21). Keck GE; Poudel YB; Rudra A; Stephens JC; Kedei N; Lewin NE; Blumberg PM Bioorg. Med. Chem. Lett 2012, 22 (12), 4084-4088. [PubMed: 22579485]

(22). Petersen ME Synthesis of structurally simplified bryostatin analogues: Probing the underlying biology and progressing towards more 'drug like' compounds; Ph.D. Thesis, University of Utah, Salt Lake City, UT, 2014.

(23). Wender PA; Cribbs CM; Koehler KF; Sharkey NA; Herald CL; Kamano Y; Pettit GR; Blumberg PM Proc. Natl. Acad. Sci. U. S. A 1988, 85, 7197-7201. [PubMed: 3174627]

(24). Kang JH; Kim SY; Lee J; Marquez VE; Lewin NE; Pearce LV; Blumberg PM J. Med. Chem 2004, 47, 4000-4007. [PubMed: 15267238]

(25). Nacro K; Bienfait B; Lee J; Han KC; Kang JH; Benzaria S; Lewin NE; Bhattacharyya DK; Blumberg PM; Marquez VE J. Med. Chem 2000, 43, 921-944. [PubMed: 10715158]

(26). Lee J; Wang S; Milne GWA; Sharma R; Lewin NE; Blumberg PM; Marquez VE J. Med. Chem 1996, 39, 29-35. [PubMed: 8568819]

(27). Nacro K; Bienfait B; Lee J; Han KC; Kang JH; Benzaria S; Lewin NE; Bhattacharyya DK; Blumberg PM; Marquez VE J. Med. Chem 2000, 43, 921-944. [PubMed: 10715158]

(28). Li W The synthetic and biological study of bryostatin analogues; Ph.D. Thesis, University of Utah, Salt Lake City, UT, 2011.

(29). Keck GE; Covel J; Schiff T; Yu T Org. Lett 2002, 4 (7), 1189-1192. [PubMed: 11922815]

(30). Vanier SF; Larouche G; Wurz RP; Charette AB Org. Lett 2010, 12 (4), 672-675. [PubMed: 20055454]

(31). Sharma GVM; Srinivas B; Krishna PR Tetrahedron Lett. 2003, 44, 4689-4691.

(32). Parikh JR; Doering WVE J. Am. Chem. Soc 1967, 89 (21), 5505-5507.

(33). Bal BS; Childers WE; Pinnick HW Tetrahedron 1981, 37 (11), 2091-2096.

(34). Kang JH; Siddiqui MA; Sigano DM; Krajewski K; Lewin NE; Pu Y; Blumberg PM; Lee J; Marquez VE Org. Lett 2004, 6 (14), 2413-2416. [PubMed: 15228292]

(35). Crimmins MT; O’Mahony R Tetrahedron Lett. 1989, 30 (44), 5993-5996. 
(36). Shiina I; Kubota M; Oshiumi H; Hashizume M J. Org. Chem 2004, 69, 1822. [PubMed: 15058924]

(37). Marshall JA; Cohen N; Arenson KR J. Org. Chem 1965, 30 (3), 762-766. [PubMed: 14285670]

(38). Solabannavar SB; Helavi VB; Desai UV; Mane RB Tetrahedron Lett. 2002, 43, 4535-4536.

(39). Mortensen MS; Osbourn JM; O’Doherty GA Org. Lett 2007, 9, 3105-3108. [PubMed: 17608433]

(40). Krainer E; Naider F Tetrahedron Lett. 1993, 34 (11), 1713-1716.

(41). Furstner A; Weintritt H J. Am. Chem. Soc 1998, 120, 2817-2825.

(42). Boden EP; Keck GE J. Org. Chem 1985, 50, 2394-2395.

(43). Higashibayashi S; Shinko K; Ishizu T; Hashimoto K; Shirahama H; Nakata M Synlett 2000, 2000, 1306-1308.

(44). Corey EJ; Venkateswarlu A J. Am. Chem. Soc 1972, 94 (17), 6190-6191.

(45). Tius MA; Fauq AH J. Am. Chem. Soc 1986, 108 (5), 1035-1039.

(46). Inanaga J; Hirata K; Saeki H; Katsuki T; Yamaguchi M Bull. Chem. Soc. Jpn 1979, 52, 19891993.

(47). Lipshutz BH; Harvey DF Synth. Commun 1982, 12 (4), 267-277.

(48). Wender PA; Koehler MFT; Wright DL; Irie K Synthesis 1999, 1999, 1401-1406.

(49). Bessodes M; Komiotis D; Antonakis K Tetrahedron Lett. 1986, 27 (5), 579-580.

(50). Cummins TJ The synthesis of the C-ring subunit of bryostatin 1, and the synthesis and biological evaluation of fluorescent bryostatin analogues; Ph.D. Thesis, University of Utah, Salt Lake City, UT, 2015.

(51). Jackson JA; Hammond GB; Wiemer DF J. Org. Chem 1989, 54, 4750-4754.

(52). Yu JS; Wiemer DF J. Org. Chem 2007, 72, 6263-6265. [PubMed: 17629340]

(53). Kofron WG; Baclawski LM J. Org. Chem 1976, 41 (10), 1879-1880.

(54). Andrews IP; Ketcham JM; Blumberg PM; Kedei N; Lewin NE; Peach ML; Krische MJ J. Am. Chem. Soc 2014, 136, 13209-13216. [PubMed: 25207655]

(55). Pettit G; Herald C; Doubek D; Herald D; Arnold E; Clardy J J. Am. Chem. Soc 1982, 104 (24), 6846-6848.

(56). MacroModel; Schrödinger, LLC: New York, 2013.

(57). Chang G; Guida WC; Still WC J. Am. Chem. Soc 1989, 111 (12), 4379-4386.

(58). Kolossváry I; Keserü GM J. Comput. Chem 2001, 22 (1), 21-30.

(59). Jorgensen WL; Maxwell DS; Tirado-Rives J J. Am. Chem. Soc 1996, 118 (45), 11225-11236.

(60). Zhang G; Kazanietz MG; Blumberg PM; Hurley JH Cell 1995, 81 (6), 917-924. [PubMed: 7781068]

(61). Jones G; Willett P; Glen RC; Leach AR; Taylor RJ J. Mol. Biol 1997, 267 (3), 727-748. [PubMed: 9126849] 


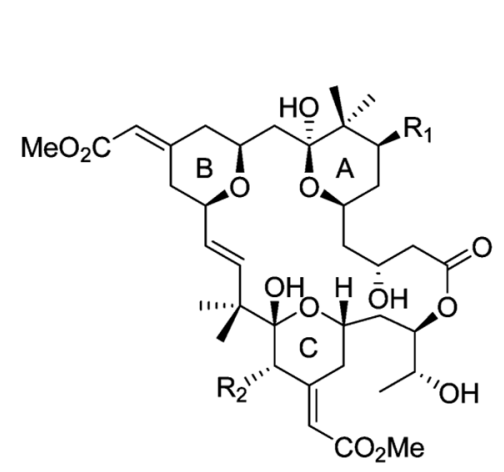

bryostatin 1

bryostatin 2

bryostatin 4

bryostatin 5

bryostatin 6

bryostatin 7

bryostatin 8

bryostatin 9

bryostatin 10

bryostatin 11

bryostatin 12

bryostatin 13

bryostatin 14

bryostatin 15

$\mathrm{R}_{1}=\mathrm{OAc}$
$\mathrm{R}_{1}=\mathrm{OH}$
$\mathrm{R}_{1}=\mathrm{OCO} t-\mathrm{Bu}$
$\mathrm{R}_{1}=\mathrm{OCO} t-\mathrm{Bu}$
$\mathrm{R}_{1}=\mathrm{OCO} n-\mathrm{Pr}$
$\mathrm{R}_{1}=\mathrm{OAc}$
$\mathrm{R}_{1}=\mathrm{OCO} n-\mathrm{Pr}$
$\mathrm{R}_{1}=\mathrm{OAc}$
$\mathrm{R}_{1}=\mathrm{OCO} t-\mathrm{Bu}$
$\mathrm{R}_{1}=\mathrm{OAc}$
$\mathrm{R}_{1}=\mathrm{OCO}(\mathrm{CH})_{4} \mathrm{Pr}$
$\mathrm{R}_{1}=\mathrm{OCO} n-\mathrm{Pr}$
$\mathrm{R}_{1}=\mathrm{OCO} t-\mathrm{Bu}$
$\mathrm{R}_{1}=\mathrm{OAc}$

$\mathrm{R}_{2}=\mathrm{OCO}(\mathrm{CH})_{4} \mathrm{Pr}$

$\mathrm{R}_{2}=\mathrm{OCO}(\mathrm{CH})_{4} \mathrm{Pr}$

$\mathrm{R}_{2}=\mathrm{OCO} n-\mathrm{Pr}$

$\mathrm{R}_{2}=\mathrm{OAc}$

$\mathrm{R}_{2}=\mathrm{OAc}$

$\mathrm{R}_{2}=\mathrm{OAc}$

$\mathrm{R}_{2}=$ OCO $n-\mathrm{Pr}$

$\mathrm{R}_{2}=\mathrm{OCO} n-\mathrm{Pr}$

$\mathrm{R}_{2}=\mathrm{H}$

$\mathrm{R}_{2}=\mathrm{H}$

$\mathrm{R}_{2}=\mathrm{OCO} n-\mathrm{Pr}$

$\mathrm{R}_{2}=\mathrm{H}$

$\mathrm{R}_{2}=\mathrm{OH}$

$\mathrm{R}_{2}=\mathrm{OCO}(\mathrm{CH})_{4}$

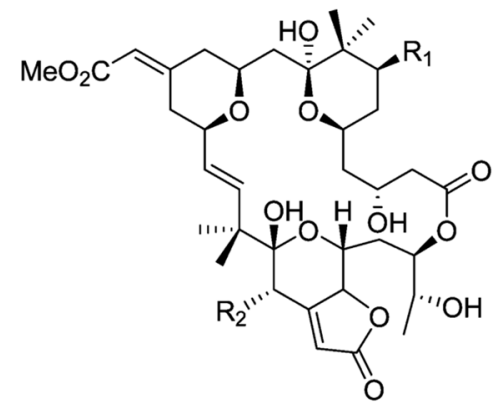

bryostatin 3

bryostatin 19

bryostatin 20

\begin{abstract}
$\mathrm{R}_{1}=\mathrm{OAc}$
$\mathrm{R}_{2}=\mathrm{OCO}(\mathrm{CH})_{4} \mathrm{Pr}$

$\mathrm{R}_{1}=\mathrm{OCOt}-\mathrm{Bu} \quad \mathrm{R}_{2}=\mathrm{OCO} n-\mathrm{Pr}$

$\mathrm{R}_{1}=\mathrm{OCOt}-\mathrm{Bu}$
\end{abstract}

\section{Figure 1.}

Bryostatin family of natural products. bryostatin 18

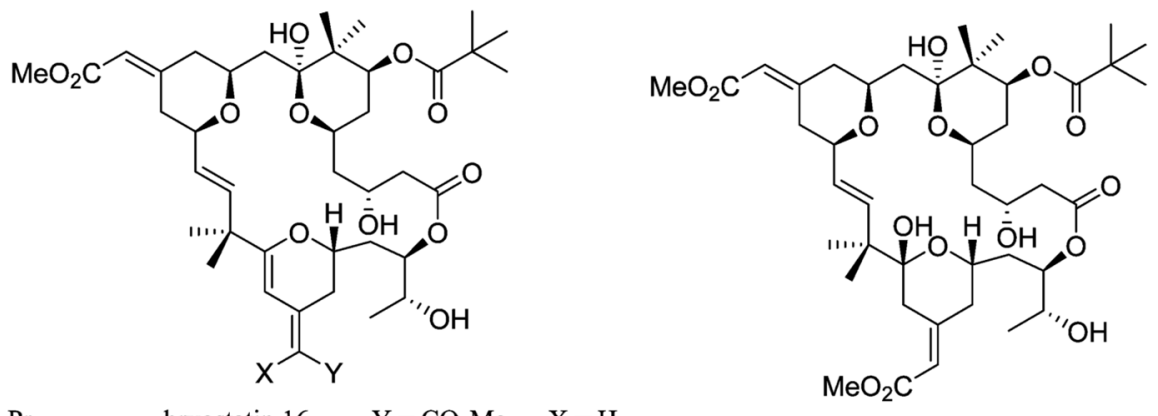

bryostatin $16 \quad \mathrm{Y}=\mathrm{CO}_{2} \mathrm{Me} \quad \mathrm{X}=\mathrm{H}$

bryostatin $17 \quad \mathrm{Y}=\mathrm{H} \quad \mathrm{X}=\mathrm{CO}_{2} \mathrm{Me}$
$\mathrm{CH}(\mathrm{OH}) \mathrm{Et}$ 


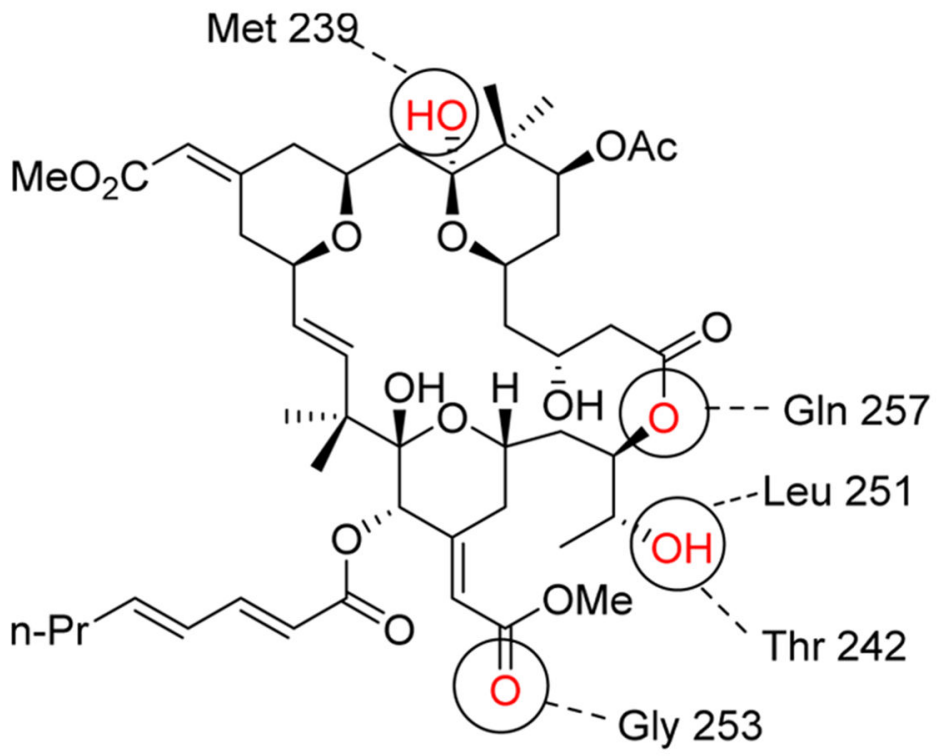

Bryostatin 1

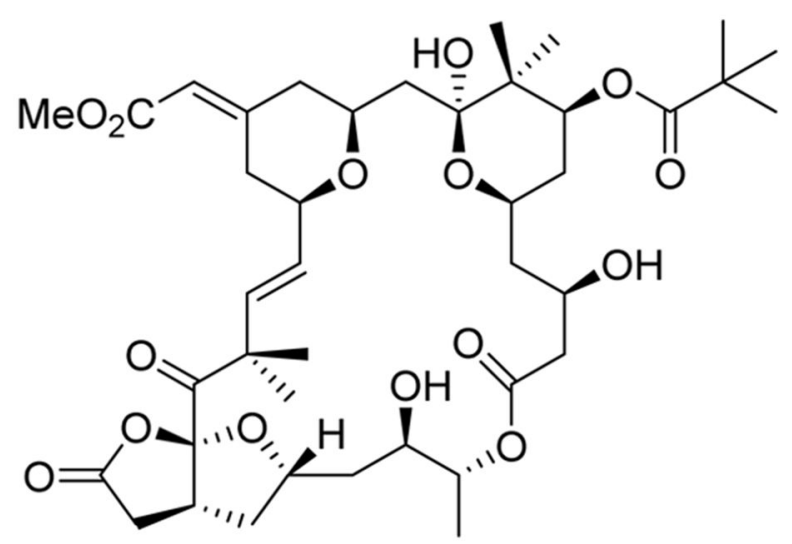

Neristatin 1

Figure 2.

Bryostatin binding hypothesis. H-bonding to PKC utilizes the residues circled. 
<smiles>CC(C)CC(C/C=C1/C[C@@](CO)(COC(=O)C(C)(C)C)OC1=O)CC(C)C</smiles><smiles>O=C1CCCCCCCCCCCCCC/C=C2/CC(CO)(CO1)OC2=O</smiles>

$$
\mathrm{K}_{i}=1.5+/-0.2 \mathrm{nM}
$$$$
\mathrm{K}_{i}=6.1+/-0.7 \mathrm{nM}
$$$$
\log P=4.65
$$

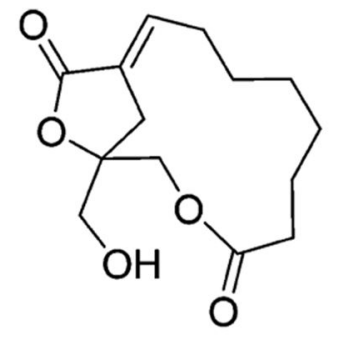

$\mathrm{K}_{i}=1800+/-250 \mathrm{nM}$

$\log P=0.89$

Figure 3.

Marquez lactones. Binding affinities to PKC alpha are indicated. Log $P$ values were calculated by ChemDraw. 

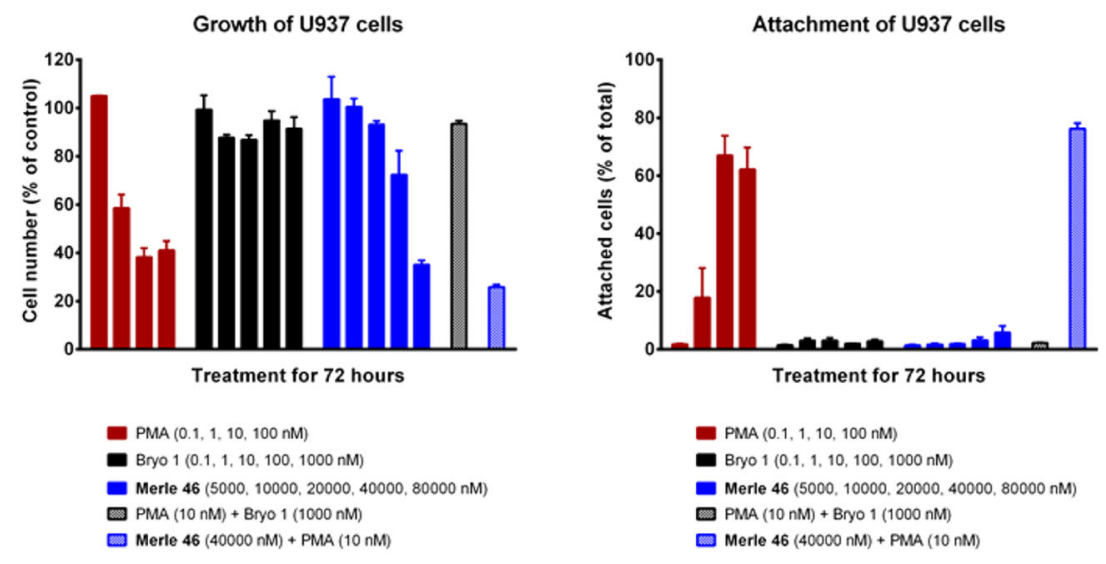

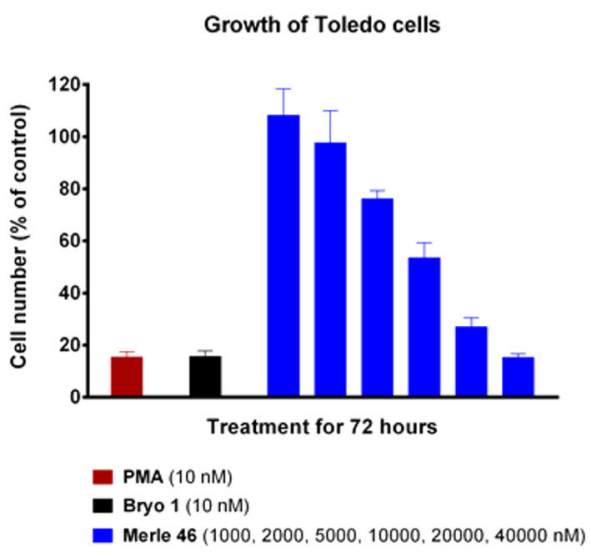

Figure 4.

Biological evaluation of Merle 46. 

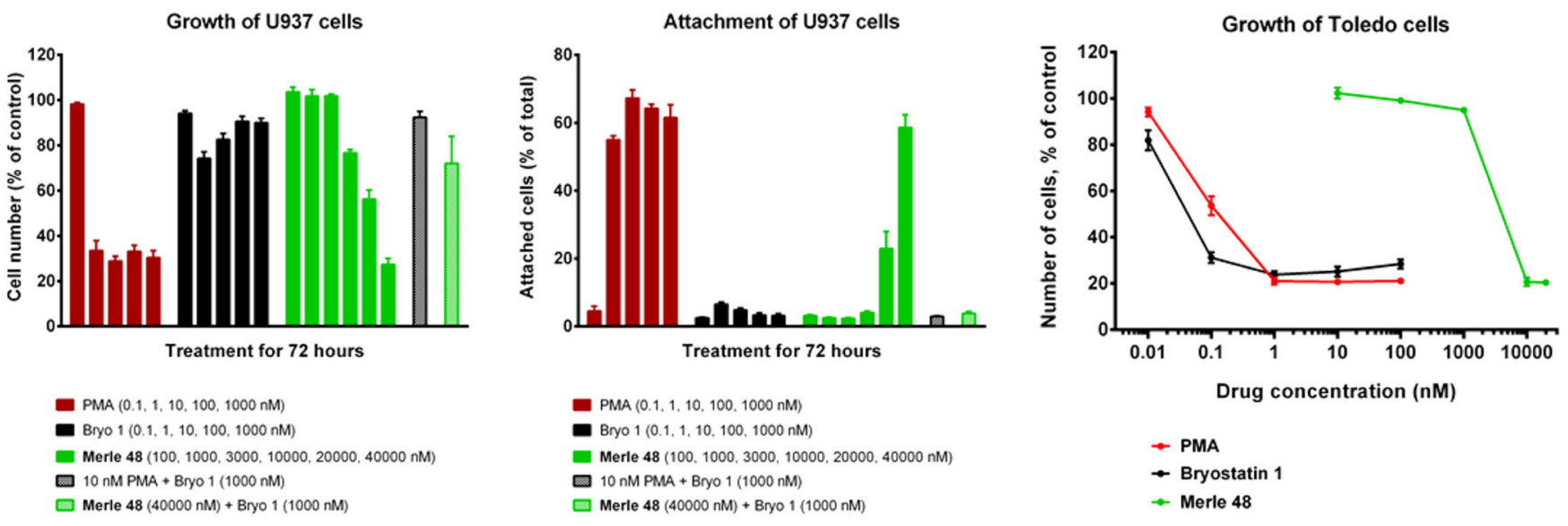

Figure 5.

Biological evaluation of Merle 48 . 


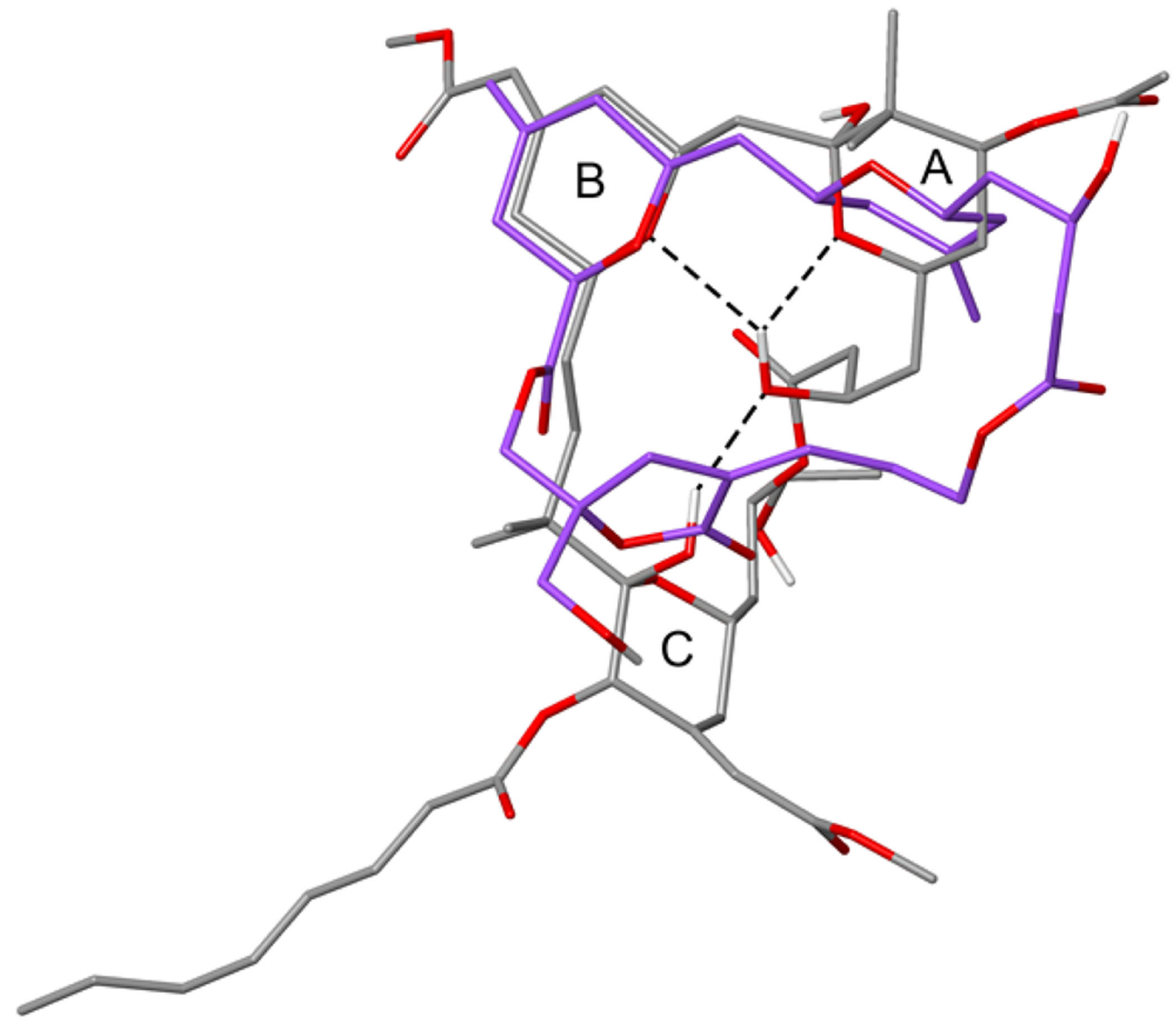

Figure 6.

Overlay of energy-minimized conformations of Merle 46 and bryostatin 1. 


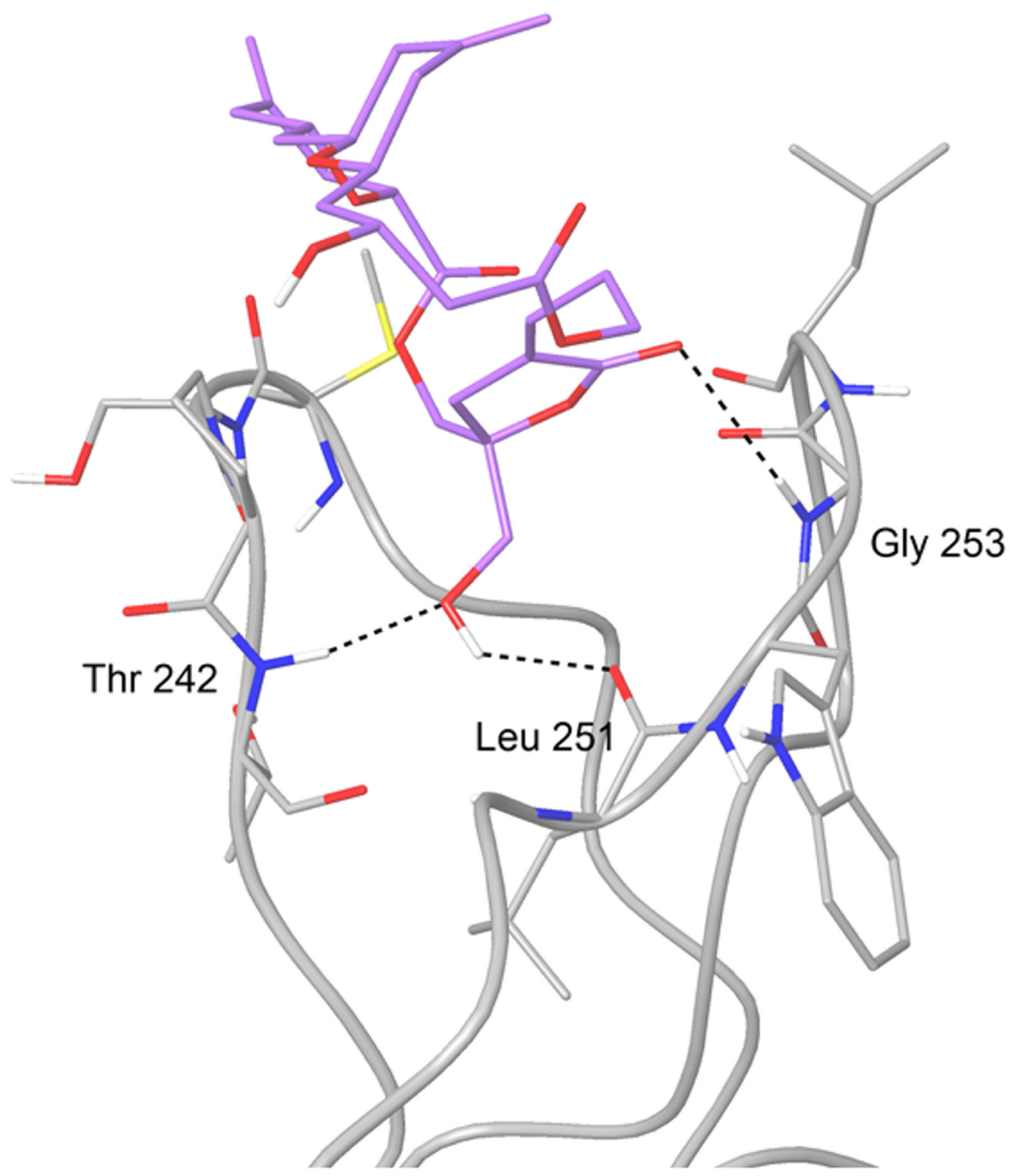

Figure 7.

Merle 46 docked to the $\mathrm{C} 1 \mathrm{~b}$ domain of PKC. 


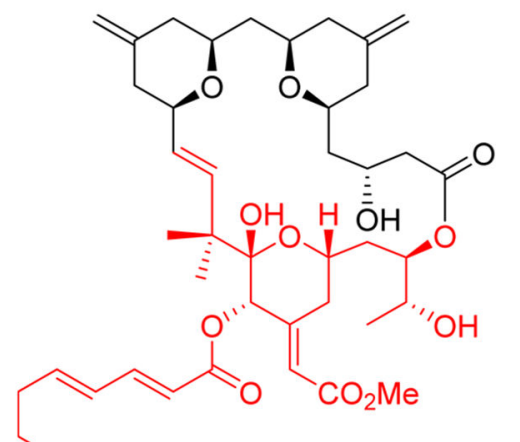

Merle 23

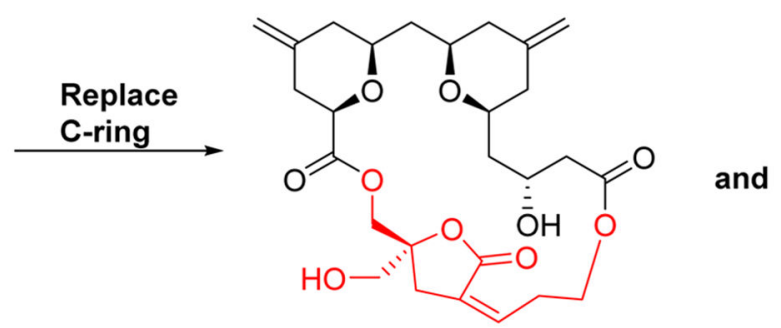

Merle 46

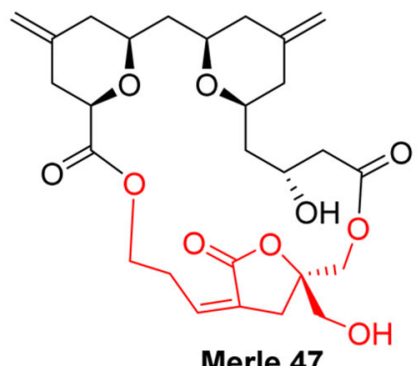

Merle 47
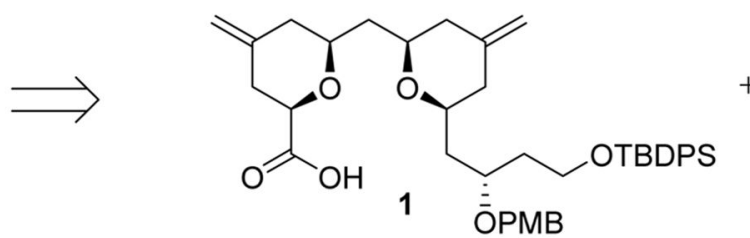

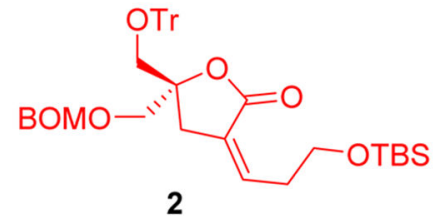

Scheme 1.

Retrosynthesis of Merles 46 and 47 


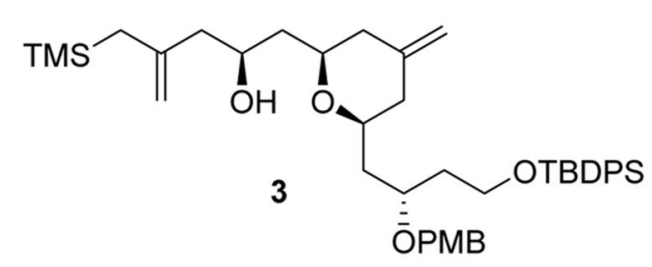
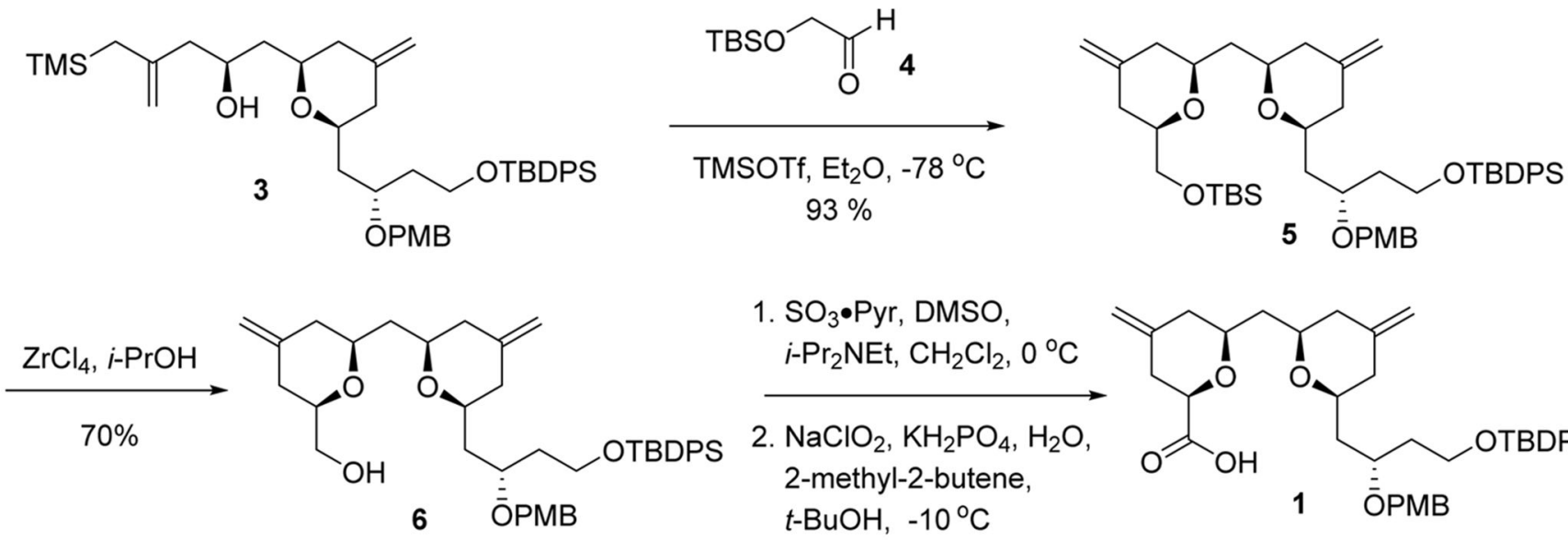

1. $\mathrm{SO}_{3} \bullet \mathrm{Pyr}, \mathrm{DMSO}$, $i$ - $\mathrm{Pr}_{2} \mathrm{NEt}, \mathrm{CH}_{2} \mathrm{Cl}_{2}, 0^{\circ} \mathrm{C}$

2. $\mathrm{NaClO}_{2}, \mathrm{KH}_{2} \mathrm{PO}_{4}, \mathrm{H}_{2} \mathrm{O}$, 2-methyl-2-butene, $t$-BuOH, $-10^{\circ} \mathrm{C}$

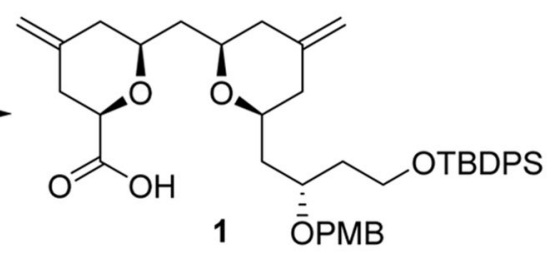
$89 \%$, 2-steps

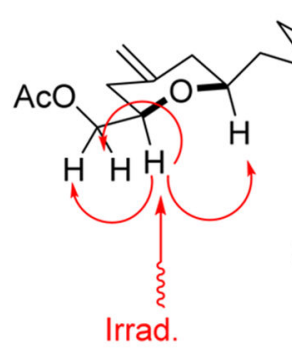

Scheme 2.

Synthesis of Carboxylic Acid 1 and Relevant NOESY Correlations of Acetate 6b 


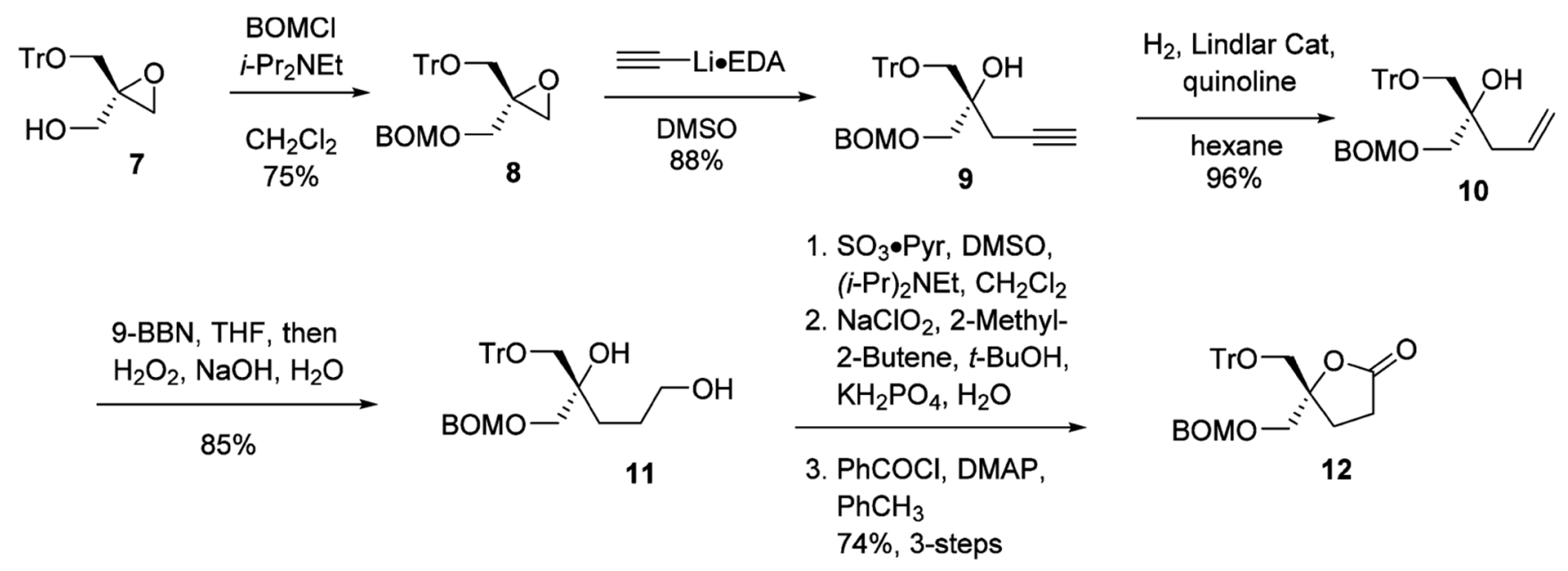

Scheme 3.

Initial Synthesis of Lactone 12 
<smiles>COC[C@]1(CO)CO1</smiles>

8
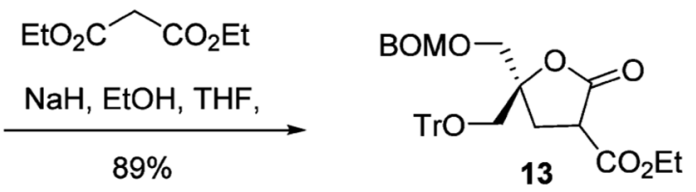

1. $\mathrm{NaOH}, \mathrm{EtOH}, \mathrm{H}_{2} \mathrm{O}$

2. Quinoline, $\mathrm{PhCH}_{3}$

$80^{\circ} \mathrm{C}$

$95 \%$, 2-steps

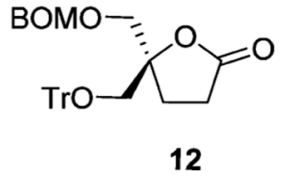

Scheme 4.

Optimized Synthesis of Lactone 12 

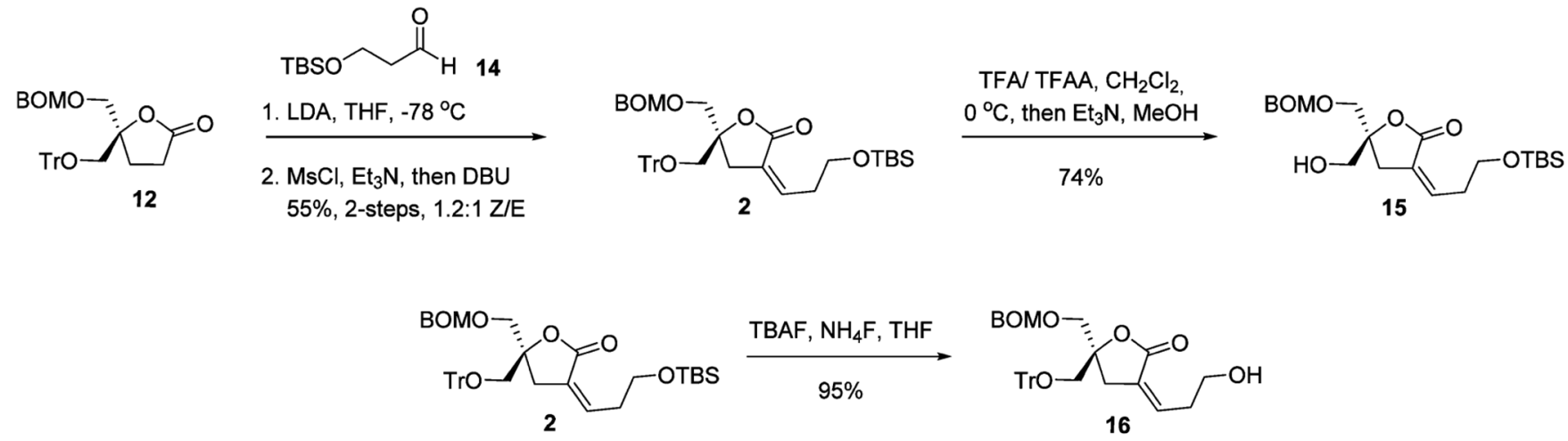

Scheme 5.

Synthesis of Enoate 2 and Deprotections Producing Alcohols 15 and 16 

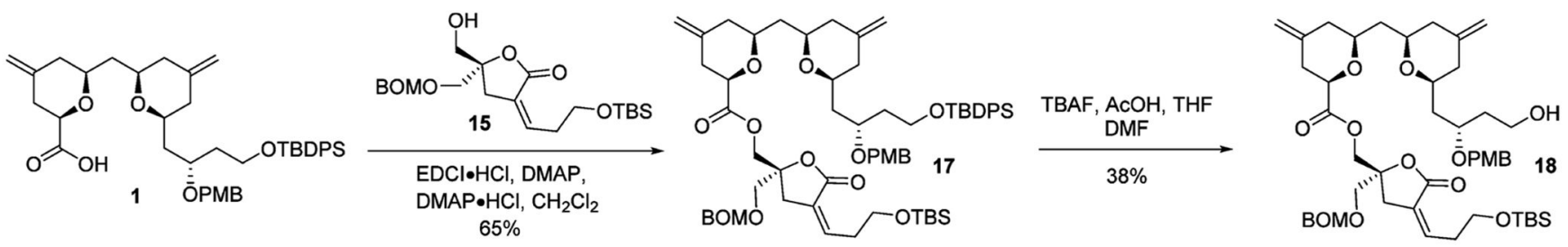

Scheme 6.

C1 Deprotection Attempt 

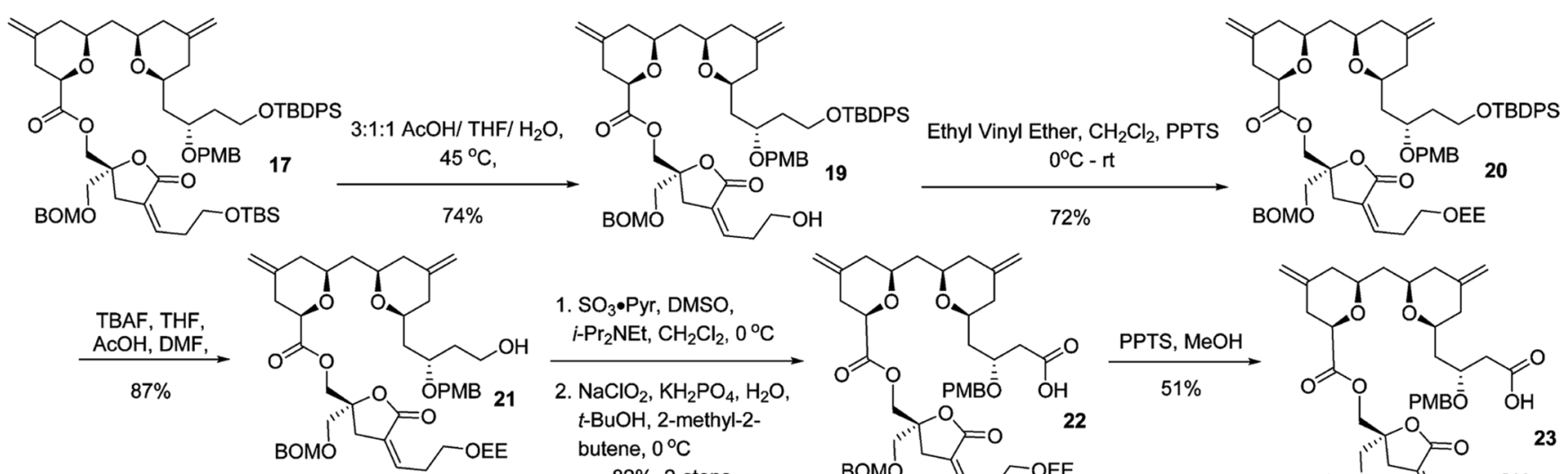

1. $\mathrm{SO}_{3} \cdot \mathrm{Pyr}, \mathrm{DMSO}$, i- $\mathrm{Pr}_{2} \mathrm{NEt}, \mathrm{CH}_{2} \mathrm{Cl}_{2}, 0^{\circ} \mathrm{C}$

2. $\mathrm{NaClO}_{2}, \mathrm{KH}_{2} \mathrm{PO}_{4}, \mathrm{H}_{2} \mathrm{O}$, $t$-BuOH, 2-methyl-2butene, $0^{\circ} \mathrm{C}$ $82 \%, 2$-steps

2,4,6-trichlorobenzoyl chloride, $\mathrm{Et}_{3} \mathrm{~N}$, DMAP, $\mathrm{PhCH}_{3}, 40^{\circ} \mathrm{C}$
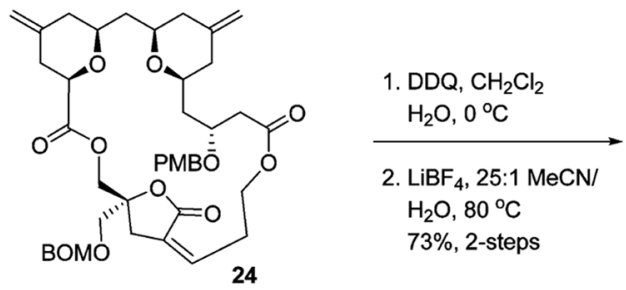

PPTS, $\mathrm{MeOH}$
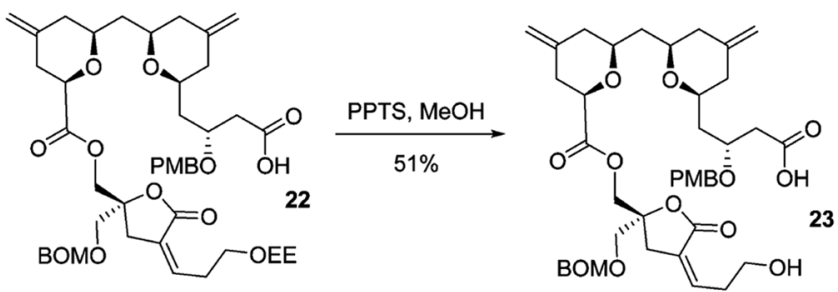

$57 \%$

$73 \%, 2$-steps

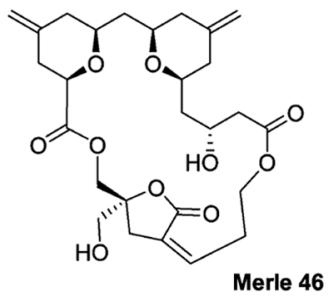

Scheme 7.

Completion of Merle 46 
<smiles>C=C1C[C@@H](C[C@H]2CC(=C)C[C@H](C(=O)O)O2)O[C@@H](C[C@@H](CCO[SbH3])OC(C)=O)C1</smiles><smiles>CC(C)(C)OC[C@]1(CO[Na])C/C(=C/CCO)C(=O)O1</smiles>

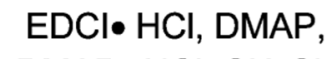

DMAP• $\mathrm{HCl}, \mathrm{CH}_{2} \mathrm{Cl}_{2}$ $38 \%$

or

2,4,6-Trichlorobenzoyl

Chloride, $\mathrm{Et}_{3} \mathrm{~N}, \mathrm{DMAP}$,

$\mathrm{PhCH}_{3}$

$61 \%$

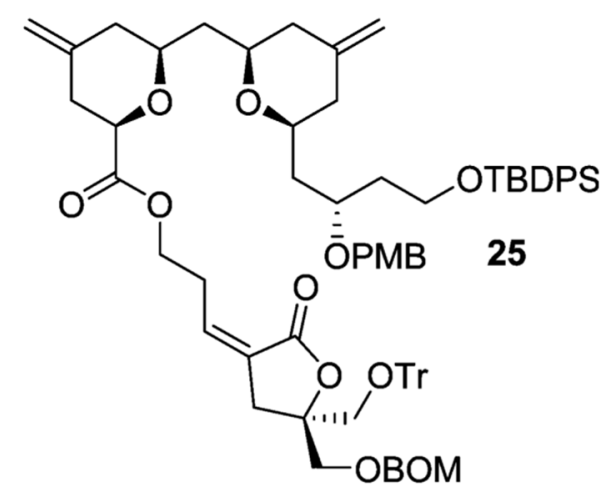

Scheme 8.

Esterification Optimization 

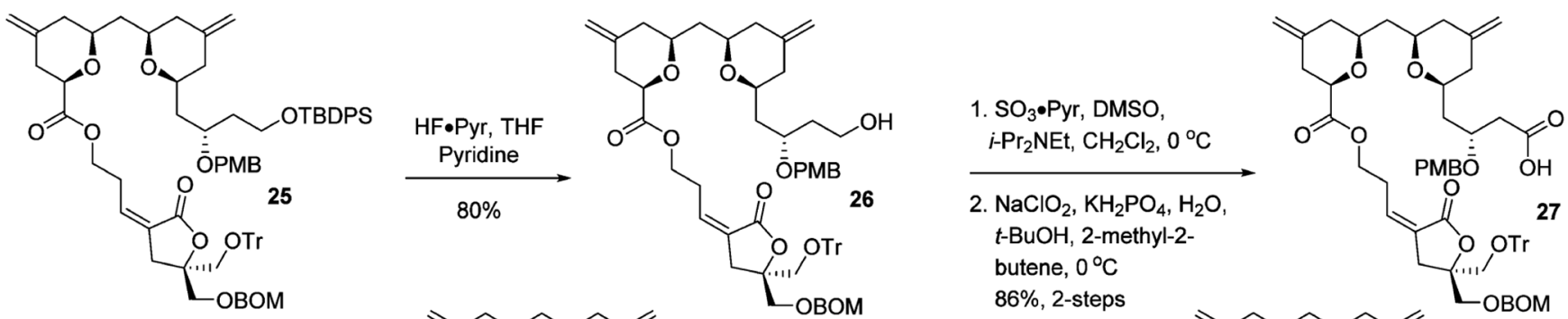

1. $\mathrm{HCOOH}, \mathrm{Et}_{2} \mathrm{O}$

2. 2,4,6-Trichlorobenzoyl chloride, $\mathrm{Et}_{3} \mathrm{~N}, \mathrm{DMAP}$, THF, $55 \%$, 2-steps

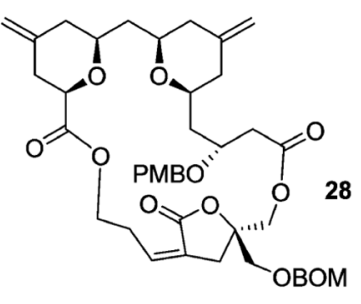

1. $\mathrm{DDQ}, \mathrm{CH}_{2} \mathrm{Cl}_{2}, \mathrm{H}_{2} \mathrm{O}$

${ }^{\circ}{ }^{\circ} \mathrm{C}$

2. $\mathrm{LiBF}_{4}, \mathrm{MeCN}, \mathrm{H}_{2} \mathrm{O}$,

$80^{\circ} \mathrm{C}$,

$36 \%$, 2-steps

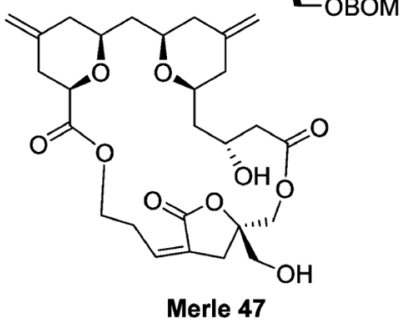

Scheme 9.

Completion of Merle 47 


\section{Pyran Annulation}

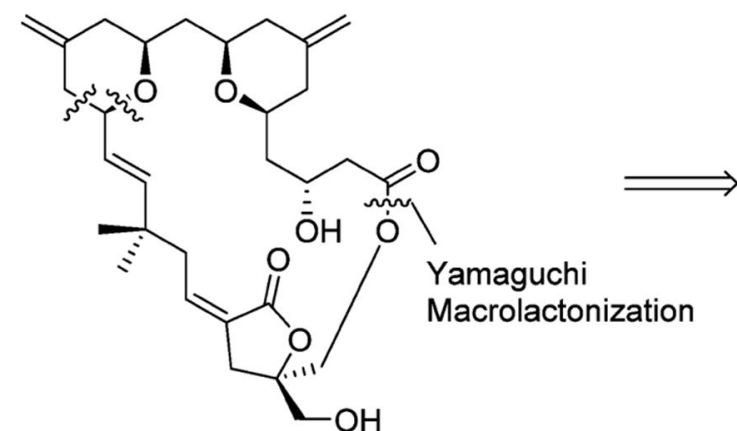

Merle 48

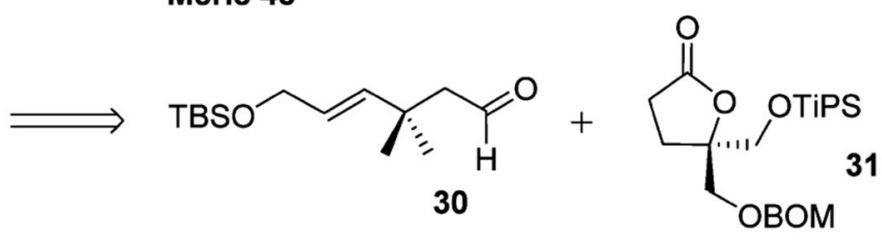

Scheme 10.

Retrosynthesis of Merle 48

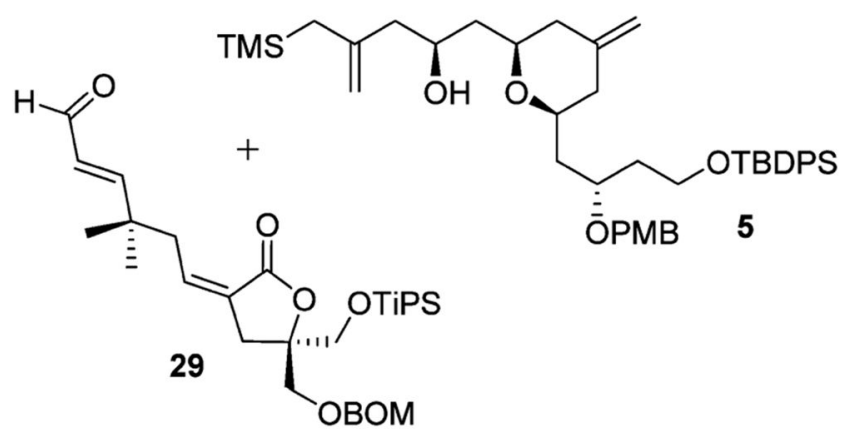

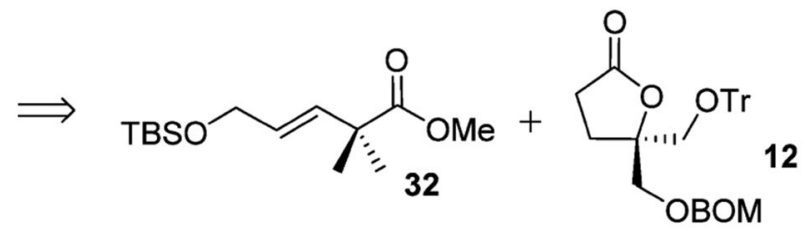




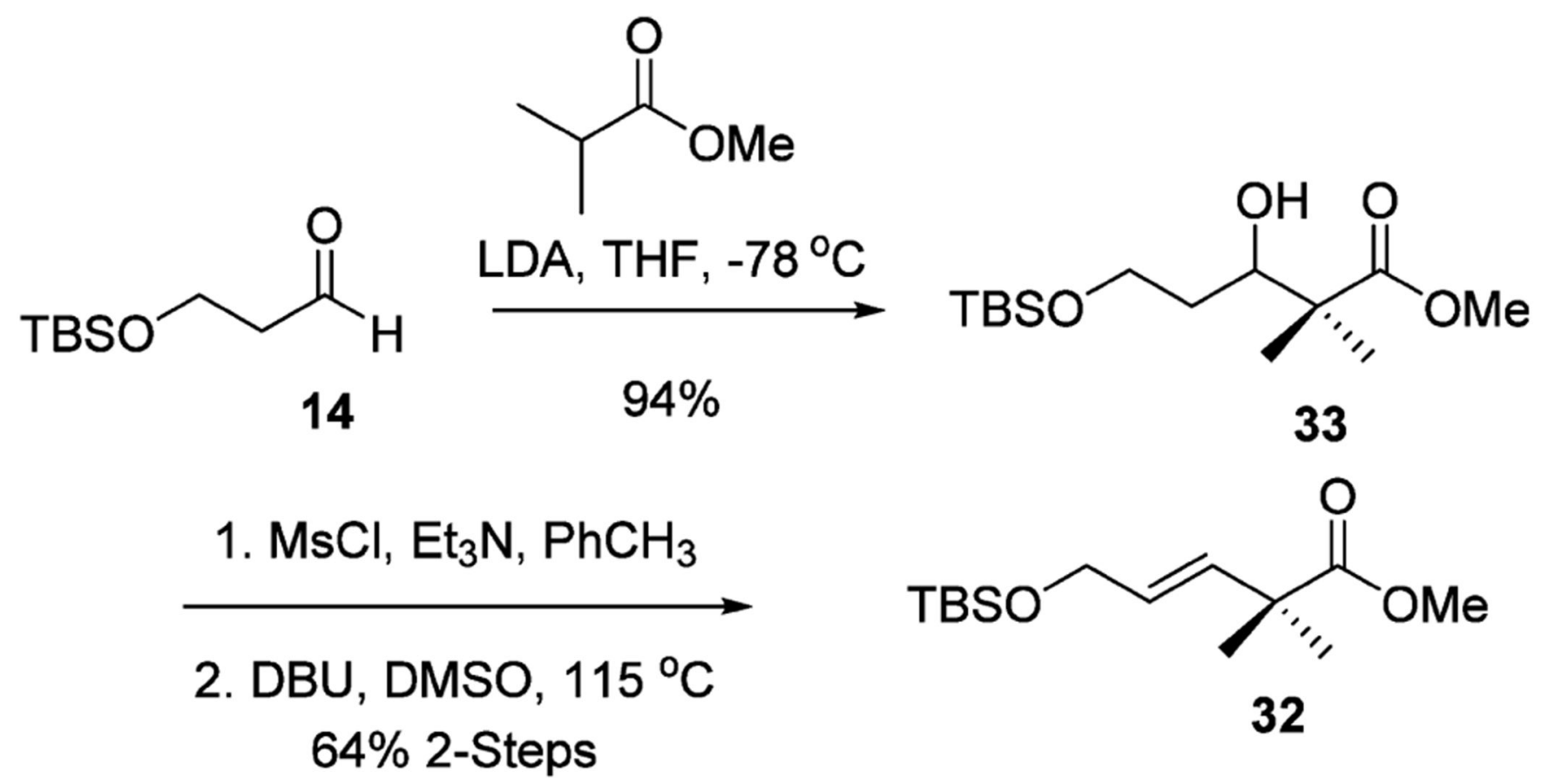

Scheme 11.

Synthesis of Ester 32 


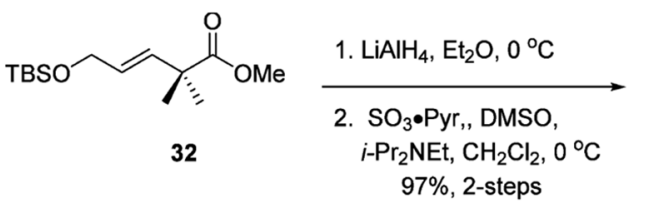

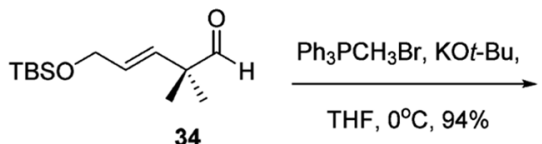<smiles>C=CC(C)(C)/C=C/COC(C)(C)C</smiles>

9-BBN, THF, J)) then $\mathrm{H}_{2} \mathrm{O}_{2}, \mathrm{NaOH}$
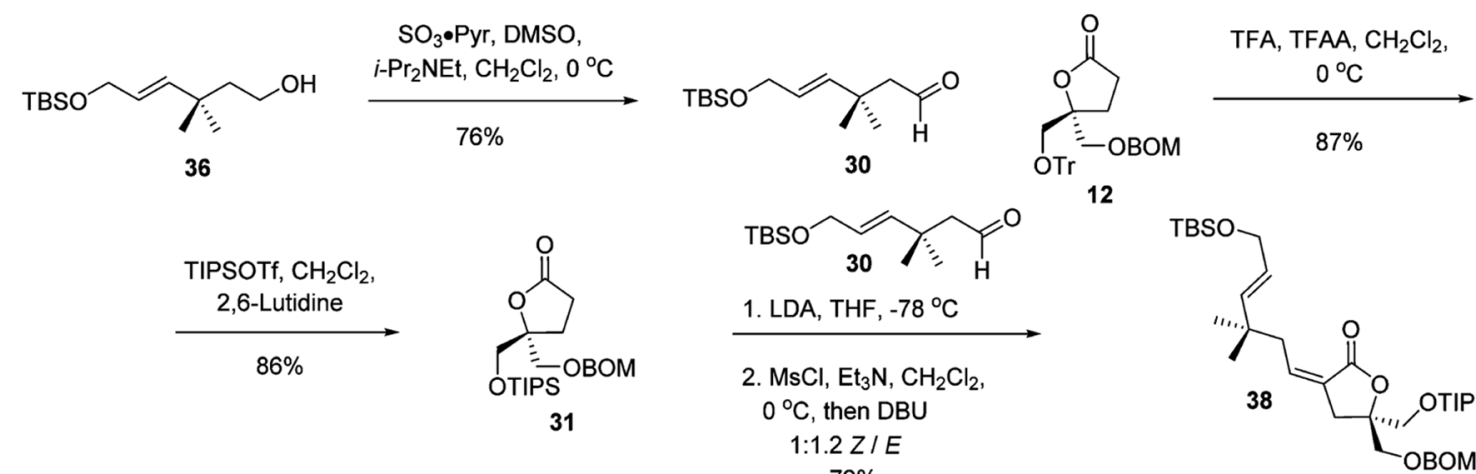

12

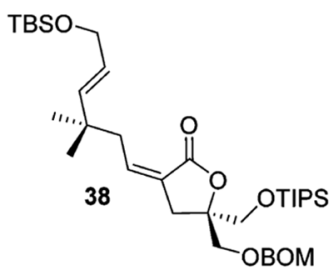

$85 \%$

Scheme 12.

Initial Approach to Enoate 38 

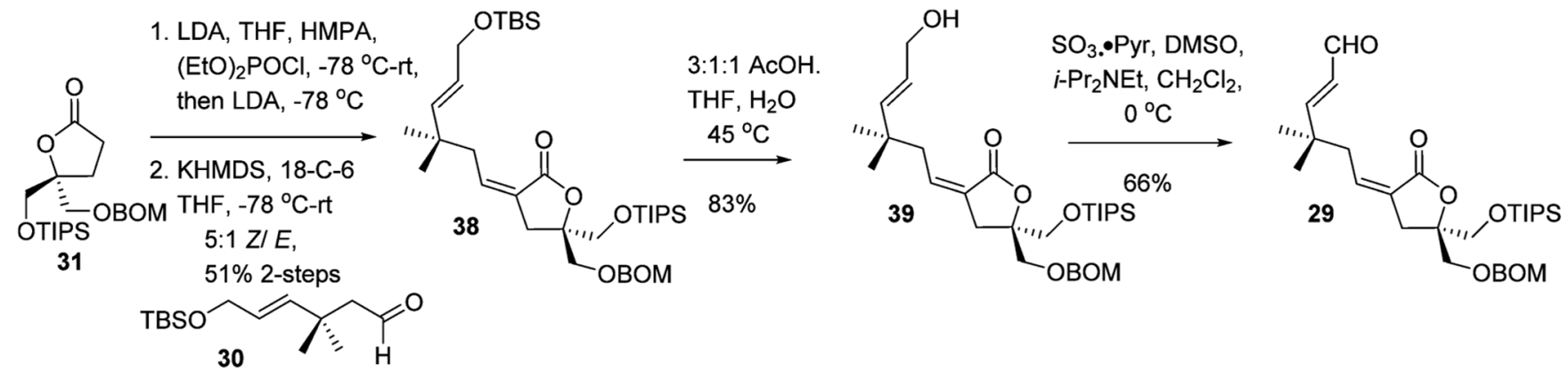

Scheme 13.

Selective HWE Olefination 


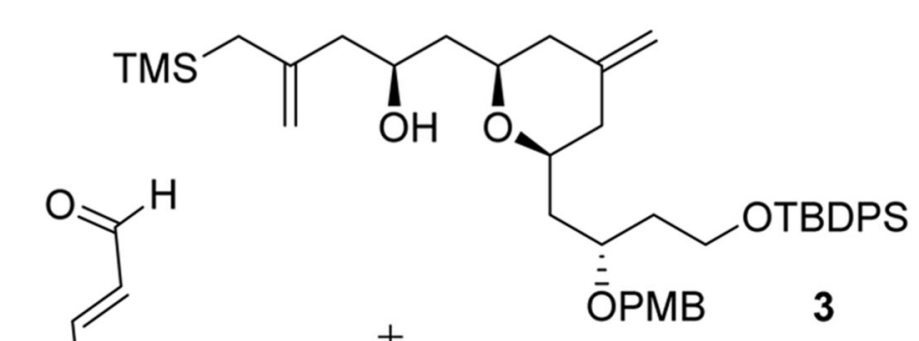

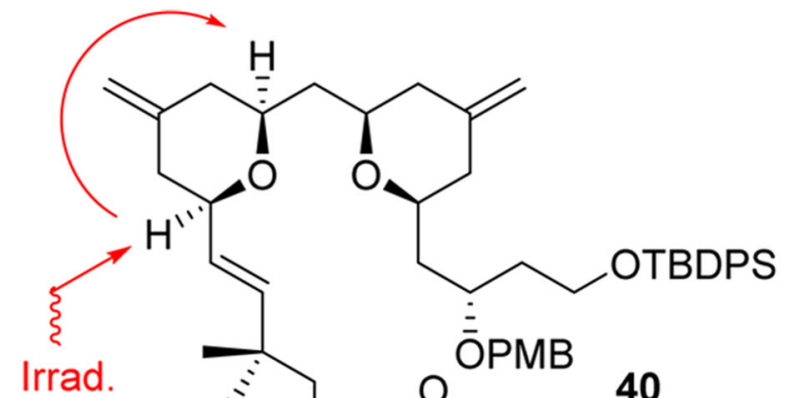

29<smiles>C=C1C[C@](COC)(CO[O+])OC1=O</smiles>

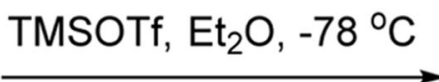

$83 \%$

Scheme 14.

Synthesis of Bispyran 40 and Relevant 1D ROESY Correlations 


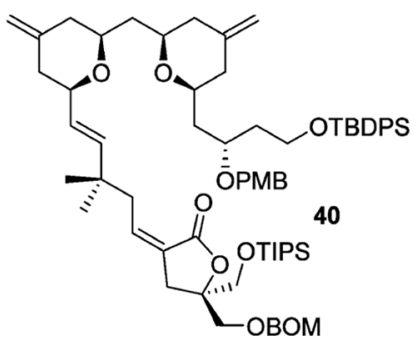

1. HF•Pyr, THF, rt

2. 2, 4, 6-Trichlorobenzoyl Chloride,

$\mathrm{Et}_{3} \mathrm{~N}$, then DMAP $\mathrm{PhCH}_{3}, 45^{\circ} \mathrm{C}$ $38 \%$, 2-steps
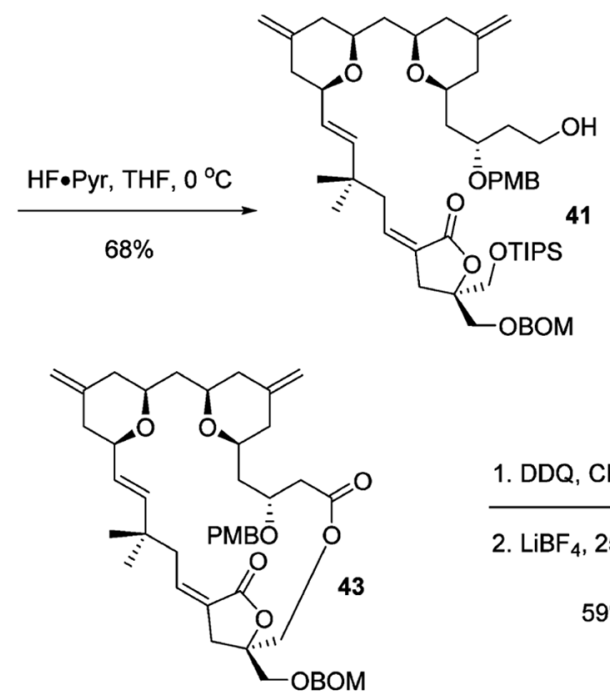

1. $\mathrm{SO}_{3} \bullet \mathrm{Pyr}, \mathrm{DMSO}$, i- $\mathrm{Pr}_{2} \mathrm{NEt}, \mathrm{CH}_{2} \mathrm{Cl}_{2}, 0^{\circ} \mathrm{C}$

2. $\mathrm{NaClO}_{2}, \mathrm{KH}_{2} \mathrm{PO}_{4}, \mathrm{H}_{2} \mathrm{O}$, $t$-BuOH, 2-methyl-2butene, $0^{\circ} \mathrm{C}$ $54 \%, 2$-steps
1. DDQ, $\mathrm{CH}_{2} \mathrm{Cl}_{2}, \mathrm{H}_{2} \mathrm{O}, 0^{\circ} \mathrm{C}$

2. $\mathrm{LiBF}_{4}, 25: 1 \mathrm{MeCN} / \mathrm{H}_{2} \mathrm{O}$,

$80^{\circ} \mathrm{C}$

59\%, 2-steps

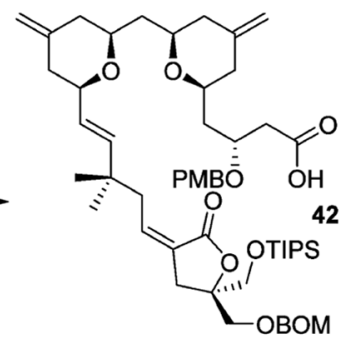

OBOM

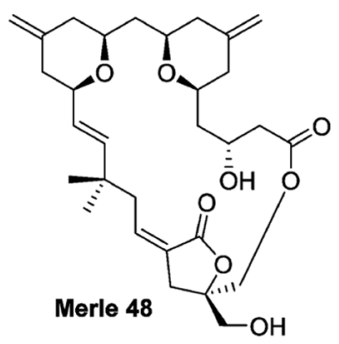

Scheme 15.

Completion of Merle 48 